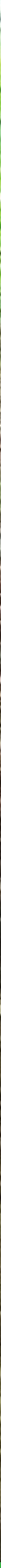

\title{
Vitaliteit en groei van bomen in relatie tot bodem en grondwater in Amelisweerd
}

Verdiepingsslag

A.P.P.M. Clerkx, J. Hilbert, U.G.W. Sass-Klaassen, J.D. Schaap, J. 't Hoen, S.P.J. van Delft,

L. Akhmetzyanov, P. Copini

WAGENINGEN

UNIVERSITY \& RESEARCH 



\section{Vitaliteit en groei van bomen in relatie tot bodem en grondwater Amelisweerd}

Verdiepingsslag

A.P.P.M. Clerkx ${ }^{1}$, J. Hilbert ${ }^{2}$, U.G.W. Sass-Klaassen ${ }^{3}$, J.D. Schaap ${ }^{1}$, J. 't Hoen ${ }^{2}$, S.P.J. van Delft ${ }^{1}$,

L. Akhmetzyanov ${ }^{3}$, P. Copini ${ }^{1}$

1 Wageningen Environmental Research

2 Copijn

3 Wageningen University- Forest Ecology and Management

Dit onderzoek is uitgevoerd door Wageningen Environmental Research in opdracht van en gefinancierd door Rijkswaterstaat.

Wageningen Environmental Research

Wageningen, december 2018

Rapport 2926

ISSN 1566-7197 
Clerkx, A.P.P.M., J. Hilbert, U.G.W. Sass-Klaassen, J.D. Schaap, J. 't Hoen, S.P.J. van Delft, L. Akhmetzyanov, P. Copini, 2018. Vitaliteit en groei van bomen in relatie tot bodem en grondwater in Amelisweerd; Verdiepingsslag. Wageningen, Wageningen Environmental Research, Rapport 2926.

62 blz.; 13 fig.; 2 tab.; 9 ref.

In Amelisweerd zijn opnamen gemaakt bij 31 bomen om de relatie tussen groei en bodem en grondwater in beeld te krijgen. De onderzochte boomsoorten zijn zomereik, beuk en gewone es. Met behulp van de kritische Zk-waarden kan worden bepaald of een boom tijdens perioden van grote droogte gevaar loopt op verdrogingsverschijnselen. Deze informatie kan tijdens werkzaamheden aan de A27 worden gebruikt om sneller mogelijke negatieve effecten op de bomen te kunnen vaststellen.

Trefwoorden: Amelisweerd, groei, bodem, grondwaterstanden

Dit rapport is gratis te downloaden van https://doi.org/10.18174/467824 of op www.wur.nl/environmental-research (ga naar 'Wageningen Environmental Research' in de grijze balk onderaan). Wageningen Environmental Research verstrekt geen gedrukte exemplaren van rapporten.

(0) 2018 Wageningen Environmental Research (instituut binnen de rechtspersoon Stichting Wageningen Research), Postbus 47, 6700 AA Wageningen, T 03174807 00, www.wur.nl/environmental-research. Wageningen Environmental Research is onderdeel van Wageningen University \& Research.

- Overname, verveelvoudiging of openbaarmaking van deze uitgave is toegestaan mits met duidelijke bronvermelding.

- Overname, verveelvoudiging of openbaarmaking is niet toegestaan voor commerciële doeleinden en/of geldelijk gewin.

- Overname, verveelvoudiging of openbaarmaking is niet toegestaan voor die gedeelten van deze uitgave waarvan duidelijk is dat de auteursrechten liggen bij derden en/of zijn voorbehouden.

Wageningen Environmental Research aanvaardt geen aansprakelijkheid voor eventuele schade voortvloeiend uit het gebruik van de resultaten van dit onderzoek of de toepassing van de adviezen.

Wageningen Environmental Research Rapport 2926 | ISSN 1566-7197

Foto omslag: Joris Schaap 


\section{Inhoud}

$\begin{array}{ll}\text { Woord vooraf } & 5\end{array}$

$\begin{array}{ll}\text { Samenvatting } & 7\end{array}$

$\begin{array}{llr}1 & \text { Inleiding } & 9\end{array}$

1.1 Aanleiding 9

1.2 Doel 9

2

$\begin{array}{ll}\text { Methode } & 11\end{array}$

$2.1 \quad$ Algemene gebiedsbeschrijving $\quad 11$

2.2 Selectie van bomen $\quad 11$

2.2.1 Bodembeschrijvingen $\quad 14$

2.2.2 Beoordeling vitaliteit en groeiontwikkeling bomen in relatie tot bodem en beworteling $\quad 15$

$\begin{array}{ll}2.2 .3 \text { Jaarringonderzoek } & 15\end{array}$

3

$\begin{array}{ll}\text { Resultaten } & 17\end{array}$

$\begin{array}{lll}3.1 & \text { Bodem } & 17\end{array}$

3.2 Conditie en groeiontwikkeling onderzochte bomen $\quad 18$

3.2.1 Algemeen conditiebeeld 18

3.2.2 Kroonontwikkeling in relatie tot omgevingsfactoren 19

$\begin{array}{ll}3.2 .3 \text { Beworteling } & 21\end{array}$

3.2.4 Aantastingen en veranderende omgevingsfactoren $\quad 22$

3.3 Groei op basis van jaarringanalyse $\quad 24$

3.3.1 Groeipatronen van de individuele bomen $\quad 24$

3.3.2 Boomsoort specifieke groeipatronen: vergelijking groei tussen
Markiezenbos en Trapeziumbos en tussen boomsoorten

$\begin{array}{ll}3.3 .3 \text { Reactie op klimaatfactoren } & 28\end{array}$

3.3.4 Samenvattende analyse jaarringgegevens 30

4.1 Effecten van grondwater op boomgroei en vitaliteit in het Markiezenbos 36

4.1.1 Gebufferd grondwatersysteem 36

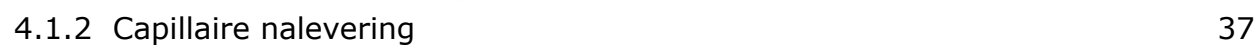

4.2 Autonome bosontwikkeling 39

4.2.1 De rol van eik en beuk $\quad 39$

4.2.2 De rol van andere boomsoorten $\quad 40$

4.2.3 Essentaksterfte en andere aantastingen $\quad 40$

4.2.4 Vernatting en verdroging $\quad 41$

4.2.5 Toekomstige bosontwikkeling 41

4.3 Conclusies $\quad 42$

$\begin{array}{ll}\text { Literatuur } & 43\end{array}$

$\begin{array}{lll}\text { Bijlage } 1 & \text { Bodemkundige gegevens } & 44\end{array}$

Bijlage 2 Boomgegevens $\quad 52$

$\begin{array}{lll}\text { Bijlage } 3 & \text { Afzonderlijke jaarringcurves van alle bomen } & 58\end{array}$ 



\section{Woord vooraf}

Het jaarringonderzoek is uitgevoerd door Ute Sass-Klaassen, Linar Akhmetzyanov, Leo Goudzwaard (WUR/FEM). De bodembeschrijvingen zijn gemaakt door Joris Schaap en Bas van Delft (WENR). 


\section{Samenvatting}

Ten behoeve van de geplande verbreding van de A27 langs de oostkant van Utrecht binnen de bestaande foliebakconstructie is een tijdelijke grondwaterstandverlaging voorzien. In het kader van de planvorming en hiermee samenhangende studies heeft Rijkswaterstaat opdracht verleend aan Deltares, Wageningen Environmental Research (WENR), Copijn Boomspecialisten B.V. en VanderSat B.V. om een 'Plan van Aanpak Effecten waardevol groen' uit te voeren. Hierin staat het bos van Amelisweerd centraal. Uit beschikbare informatie over het bos, groei en vitaliteit werd geconcludeerd dat een verdiepingsslag wenselijk was betreffende het verband tussen de vitaliteit en ontwikkeling van de bomen, de bodemeigenschappen en het grondwatergedrag. Om het samenspel van diverse factoren scherper te krijgen, is door de specialisten van WENR en Copijn een verdiepende veldstudie uitgevoerd bij een aantal referentiebomen, waarvan boven- en ondergrondse boomparameters, bodemeigenschappen met een focus op de rol van het grondwater en diverse omgevingsfactoren zijn opgenomen. Het doel van de verdiepingsslag is de relatie tussen bodemopbouw, beworteling en capillaire nalevering beter in beeld te krijgen. Daarnaast is gekeken hoe de groei in de afgelopen decennia is geweest om na te gaan of er aanwijzingen zijn voor recente vitaliteitsvermindering of dat er effecten van eerdere grondwaterstandwijzingen kunnen worden aangetoond. Dit onderzoek is uitgevoerd in het Markiezenbos op Nieuw-Amelisweerd, omdat hier vanwege de ligging direct naast de A27 de grootste invloed van de wegwerkzaamheden wordt verwacht. Het Trapeziumbos op Oud-Amelisweerd wordt als referentiebos meegenomen.

Het onderzoek spitst zich toe op de drie hoofdboomsoorten zomereik, beuk en gewone es. Er zijn 25 bomen in het Markiezenbos en 6 referentiebomen in het Trapeziumbos geselecteerd voor het onderzoek. Bij elke boom is een beschrijving van de bodem en de beworteling gemaakt. Alle bomen zijn beschreven op uiterlijke kenmerken en er zijn jaarringmonsters genomen om de groei van de bomen te analyseren.

In het algemeen is de bodemopbouw vanaf maaiveld een overgang van lichte klei in de bovengrond naar zware klei in de ondergrond, waaronder weer een zandlaag ligt. De bovengrondtextuur kan verschillen van zware zavel tot zware klei, met een enkele ophoging of bijmenging met zand aan maaiveld. De kleilagen waren op sommige locaties zo zwaar en compact dat het zelfs met een graafmachine moeilijk was om de grond laagsgewijs naar de diepte toe af te schrapen. De zwaardere kleilaag kan zeer stagnerend werken voor vocht/regenwater van bovenaf, maar ook een belemmering zijn voor de wortels. Deze zwaardere kleilaag is niet overal duidelijk aangetroffen.

Uit profielkuilen die op kleine afstand (soms minder dan $20 \mathrm{~m}$ ) van elkaar liggen, komt relatief grote variatie voor in de begin- en einddiepte van de verschillende textuurlagen. Hieruit volgt dat de bodemopbouw in Amelisweerd op kleine schaal een grote variatie vertoont. De beworteling lijkt zich vooral in de ondiepere, minder zware kleilagen te concentreren, hoewel er ook diepere wortels in de zware klei voorkomen, maar met een kleinere dichtheid. Waar het zand begint, is meestal ook het einde van de bewortelbare diepte. Opvallend is dat beuk, normaal gesproken een hartwortelaar en daardoor wat oppervlakkiger wortelend dat eik en es, in Amelisweerd dieper wortelt dan beide andere soorten.

Omdat geen zieke bomen zijn geselecteerd, vallen de meeste onderzochte bomen qua conditie binnen de categorieën goed en voldoende. Slechts enkele exemplaren zijn ingedeeld binnen de categorie matig. De bomen met een relatief gezond uiterlijk blijken niet altijd de beste groeiers te zijn. Uit de jaarringanalyses blijkt dat de groeipatronen zowel tussen soorten, maar ook binnen de drie soorten sterk variëren. De groeitrends zijn gedeeltelijk beïnvloed door de leeftijd van de bomen. Met name de oudere eiken en essen laten een sterke leeftijdstrend zien. Uit de jaarringreeksen van de afzonderlijke bomen van eik, es en beuk zijn geen consistente groeidepressies in het begin van de jaren 80 (aanleg van de A27) en eind jaren 90 (aanpassing grondwaterstanden) af te lezen. De meeste bomen laten alleen groeidepressies zien in extreem droge jaren (1959, 1976, 1996). Uit de klimaatgroei-analyse kan worden geconcludeerd dat de groei van eik, es en beuk op Amelisweerd in het algemeen positief wordt beïnvloed door veel neerslag. Eik en es profiteren met name van veel neerslag in de herfst en winter voor het groeiseizoen en natte condities in het begin van het groeiseizoen, in mei en juni. De groei van beuk is sterker afhankelijk van goede weersomstandigheden tijdens het groeiseizoen dan de 
beide andere soorten. De (groei van) beuk profiteert van natte en koele omstandigheden van mei tot juli. Droge condities in deze periode leiden tot smalle jaarringen bij beuken. Er zijn geen groeiverschillen gevonden tussen het Markiezenbos en het Trapeziumbos.

Op basis van de kritische Zk-waarde als maat voor de capillaire nalevering uit de ondergrond, is de minimale grondwaterstand berekend die bereikt kan worden zonder dat er verdrogingsgevaar voor de boom optreedt. Dit is gedaan door de Zk op te tellen bij de werkelijk bewortelingsdiepte (BEW). De kritische grondwaterstand die hieruit volgt, is vergeleken met de laagste grondwaterstanden die in lokale peilbuizen is gemeten. Hiermee is voor alle bomen berekend of in tijden van droogte gevaar op droogtestress bestaat. Dit blijkt voor een aantal bomen het geval te zijn. Met name de zone net ten noorden van de Koningsweg blijkt een kwetsbare zone voor verdroging, maar ook meer noordwaarts komen plekken voor die droogtegevoelig blijken.

De kritische grondwaterstanden zijn niet eenduidig te correleren met groei en vitaliteitskenmerken. Bomen met een goede conditie kunnen een mindere gemiddelde groei hebben dan bomen met een iets mindere conditie. Er kan dus niet op basis van uiterlijke kenmerken worden gemonitord of de bomen droogtestress gaan vertonen.

Vernatting is in delen van het bos een probleem. De grond is hier in de wintermaanden regelmatig zompig en er heersen omstandigheden die voor veel boomsoorten ongunstig zijn. Het gaat hierbij vooral om het centrale deel van het Markiezenbos waar de populier is aangeplant. Op basis van het veldonderzoek is geconstateerd dat dit het gevolg is van de zeer compacte kleilaag die op sommige plekken vrij ondiep is aangetroffen. In natte tijden stagneert regenwater op deze laag en kan niet of slechts heel langzaam naar beneden wegsijpelen.

Uit de jaarringanalyses blijkt dat de onderzochte bomen in het verleden geen negatieve groeireactie op bekende grondwaterdalingen hebben laten zien tijdens de aanleg van de A27 begin jaren 80 en eind jaren 90. Dit duidt op plasticiteit van de onderzochte bomen in reactie op veranderende groeiomstandigheden. Uit de analyses van de peilbuisdata is geconcludeerd dat er in Amelisweerd sprake is van een gebufferd grondwatersysteem, dat wordt gevoed door infiltratie vanuit de Kromme Rijn. De evapotranspiratie die overdag plaatsvindt, wordt 's nachts aangevuld, zodat het grondwater net weer een paar centimeter stijgt, ook wanneer er geen regenwater is gevallen. Het grondwatersysteem in het Markiezenbos wordt ook gebufferd door toestroom van grondwater dat geïnfiltreerd is op de Utrechtse Heuvelrug. Alhoewel Amelisweerd niet gekarakteriseerd kan worden als een kwelgebied, kan de voeding met regionaal grondwater er wel voor zorgen dat de grondwaterstand niet te ver wegzakt. Deze buffering door oeverinfiltratie vanuit de Kromme Rijn en de regionale kwel levert een positieve bijdrage aan de overleving van het bos tijdens drogere perioden.

Op basis van de verzamelde gegevens is de verwachting voor de komende paar decennia dat het bos op hoofdlijnen gedomineerd zal blijven door eik en beuk. Het aandeel eik zal geleidelijk iets kleiner kunnen worden, maar ook onder beuk kan sterfte door ouderdom gaan optreden, om de simpele reden dat beuk veel minder oud kan worden dan eik. De afname van es zal verder toenemen, maar es zal nog niet helemaal verdwijnen. 


\section{$1 \quad$ Inleiding}

\section{$1.1 \quad$ Aanleiding}

Ten behoeve van de geplande verbreding van de A27 langs de oostkant van Utrecht binnen de bestaande foliebakconstructie is een tijdelijke grondwaterstandverlaging voorzien. Deze grondwaterstandverlaging is noodzakelijk om de verbredingswerkzaamheden binnen de bestaande folieconstructie mogelijk te maken. Zonder deze drukverlaging is het risico van openbarsten tijdens aanlegwerkzaamheden te groot, met onacceptabel grote gevolgen voor het verkeer op de A27. In het kader van de planvorming en hiermee samenhangende studies heeft Rijkswaterstaat opdracht verleend aan Deltares om een 'Plan van Aanpak Effecten waardevol groen' uit te voeren. Hierin staat het bos van Amelisweerd centraal.

Deltares voert dit project uit in samenwerking met specialisten van Wageningen Environmental Research (WENR), Copijn Boomspecialisten B.V. en VanderSat B.V.

Voor het opstellen van het 'Plan van Aanpak Effecten waardevol groen' wordt een studie in meerdere fases uitgevoerd. Op 12 juli 2018 is door Deltares een conceptrapport opgesteld dat een gezamenlijk product is van de vier betrokken partijen en de resultaten van fase 1 van het project beschrijft: inventarisatie en analyse beschikbare gegevens (Van der Grift et al., 2018). Dit betreft de bevindingen van de gesprekken met verschillende stakeholders die ten behoeve van de gegevensinventarisatie zijn gehouden en het veldbezoek aan Amelisweerd door experts en stakeholders. Daarnaast geeft dit rapport per component (bomen, bodem, grondwater, oppervlaktewater, overig waardevol groen) een overzicht van de beschikbare data en daaropvolgende aanbevelingen voor de analysefase. Ten slotte is, op basis van de beschikbare data, per component een analyse uitgevoerd om vast te stellen of er in de afgelopen decennia trendmatige veranderingen zijn geweest in de bodemvochttoestand, de grondwaterstanden, oppervlaktewaterpeilen en de groei van de bomen. Dit alles om vast te stellen of het mogelijk is om een uitspraak te doen wat er met de bomen kan gebeuren als de grondwatersituatie tijdelijk verandert.

\section{Aanbeveling tot een verdiepingsslag}

In de conclusies en aanbevelingen in het rapport uit fase 1 (analyse beschikbare gegevens en veldbezoek, Van der Grift et al., 2018) is aangegeven dat een verdiepingsslag wenselijk was betreffende het verband tussen de vitaliteit en ontwikkeling van de bomen, de bodemeigenschappen en het grondwatergedrag. Met de beschikbare gegevens kan alleen een globale inschatting gemaakt worden van de kwetsbaarheid van de bomen bij een verandering van de grondwatersituatie. Om het samenspel van diverse factoren scherper te krijgen, is door de specialisten van WENR en Copijn een plan uitgewerkt voor een verdiepende veldstudie om bij een aantal referentiebomen boven- en ondergrondse boomparameters, bodemeigenschappen met een focus op de rol van het grondwater en diverse omgevingsfactoren op te nemen. Dit rapport beschrijft deze aanvullende inventarisatie en analyses.

\subsection{Doel}

Het doel van de verdiepingsslag is antwoorden te krijgen op de volgende vragen:

- Welke relatie bestaat er tussen de bodemopbouw en capillaire nalevering vanuit de ondergrond: wanneer is de grondwaterstand zo laag ten opzichte van de bewortelde zone dat nalevering vanuit de ondergrond niet meer plaatsvindt en er droogteschade aan de boom kan optreden?

- In hoeverre is er sprake van storende kleilagen waarop water kan stagneren bij een eventuele retourbemaling, zodanig dat er schade aan de bomen optreedt door vernatting?

- Wat is de langjarige groeistatus van de bomen? 
- Zijn er in het verleden abrupte veranderingen in het groeiniveau van bomen opgetreden wat kan duiden op invloed van veranderingen in het grondwaterniveau begin jaren 80 (aanleg van de A27), eind jaren 90 (aanpassing grondwaterstanden)?

- Wat is de actuele groeistatus van de onderzochte bomen, d.w.z. zijn er aanwijzingen voor recente vitaliteitsvermindering door - voor es - de essentaksterfte of andere, verder onbekende oorzaken?

- Kan m.b.v. klimaatgroeianalyses worden aangetoond dat specifieke klimaatcondities tot mogelijke versterking van het effect van grondwaterstandveranderingen kunnen leiden?

- Wat is de autonome ontwikkeling van het bos? 


\section{Methode}

\subsection{Algemene gebiedsbeschrijving}

\section{Landgoed Amelisweerd}

Het landgoed Amelisweerd vormt onderdeel van een reeks landgoederen, parken en lanen die zich uitstrekken van Wijk bij Duurstede westwaarts tot Woerden en noordwaarts tot Breukelen. Al die landgoederen hebben gemeen dat ze:

- liggen op deels kalkhoudende kleiige en zandige rivierafzettingen, afgezet door de Kromme Rijn, Oude Rijn en Vecht;

- oude bomen (vaak >150 jaar) in laanstructuren en bosopstanden bevatten;

- een lange historie van continu beheer kennen.

In Amelisweerd zijn deze kenmerken bijzonder duidelijk aanwezig. Er is sprake van een relatief groot areaal aan gesloten bos en boslanen met een groot aantal oude, dikke monumentale bomen. Tevens ligt er een groot aantal dikke, dode boomstammen. Voor Amelisweerd geldt ook dat de recreatiefunctie erg belangrijk is en voor veel mensen gemakkelijk bereikbaar is vanwege de openbare toegankelijkheid van het gebied en de nabijheid van de stad Utrecht.

$\mathrm{Al}$ in de Middeleeuwen is er sprake van drie ridderhofsteden waaruit de landgoederen OudAmelisweerd, Nieuw-Amelisweerd en Rhijnauwen zijn ontwikkeld. In de volgende eeuwen zijn de landgoederen enkele malen flink omgevormd. Patronen uit de zeventiende- en achttiende-eeuwse elementen (lanen en structuren) zijn op zowel Oud-Amelisweerd als Nieuw-Amelisweerd nog steeds zichtbaar. Ook oude zeventiende-eeuwse bomen zijn nog steeds aanwezig. In dit onderzoek is het Markiezenbos op Nieuw-Amelisweerd en het Trapeziumbos op Oud-Amelisweerd betrokken. Andere delen en landgoed Rhijnauwen worden in dit rapport verder buiten beschouwing gelaten.

Het Markiezenbos wordt gedomineerd door (zomer)eik, beuk en gewone es. De leeftijd van deze soorten loopt sterk uiteen. De ontstaansgeschiedenis van het huidige bos voert tot ongeveer 1800 , toen het landgoed volledig werd heringericht (Van Wirdum, 1981). Een deel van de oudste eiken is mogelijk van daarvóór (bomen van circa 1790 zijn aangeboord). Volgens cultuurhistorisch onderzoek zijn ook de eerste beuken aan het begin van de 19de eeuw ingebracht (Maes, 2009), maar over het algemeen zijn de beuken iets jonger dan de eiken (deze studie). De es is in het noordelijke deel al langere tijd aanwezig als hakhout en spaartelgen. De oudste stoven stammen waarschijnlijk uit de $18^{\text {de }}$ eeuw (Maes, 2009). In het begin van de $19^{\text {de }}$, maar vooral in $20^{\text {ste }}$ eeuw is in het Markiezenbos ook es als opgaande boomsoort aangeplant. Restanten van een groter bestand van Ruwe iepen komen verspreid voor en ook zoete kers, gewone esdoorn, populier en haagbeuk komen in kleinere aantallen voor.

Het Trapeziumbos kenmerkt zich door een menging van zomereik, beuk en gewone es. Dit bos werd in zijn huidige staat aangelegd in 1808 met eik en beuk. Gewone es, gewone esdoorn, zoete kers, iep en plataan zijn in de tweede helft van de negentiende eeuw ingebracht (Maes, 2009).

Een uitgebreide beschrijving van de cultuurhistorie van de landgoederen is te vinden in Albers (2009).

\subsection{Selectie van bomen}

Het onderzoek is gericht op drie soorten: beuk (Fagus sylvatica), gewone es (Fraxinus excelsior) en zomereik (Quercus robur). Dit zijn de hoofdboomsoorten in het Markiezenbos en Trapeziumbos, die al vele decennia gericht aangeplant en beheerd worden. Bij de selectie van de bomen is gestratificeerd naar grondwatertrap (Gt VII versus natter), de conditie (vitaal versus niet-vitaal) en, indien van toepassing, naar leeftijd (oud versus jonger). Het Markiezenbos wordt gezien als het kwetsbaarste deel van Amelisweerd gezien de ligging langs de A27 waar de wegverbreding is gepland. Om 
eventuele invloeden van andere aard dan in verband te brengen met grondwaterschommelingen als gevolg van de aanleg van de A27, is het Trapeziumbos op Oud-Amelisweerd aangewezen als referentiegebied. Er is hierbij uitgegaan van een bufferende werking door de Kromme Rijn tegen de effecten van grondwaterschommelingen bij de aanleg.

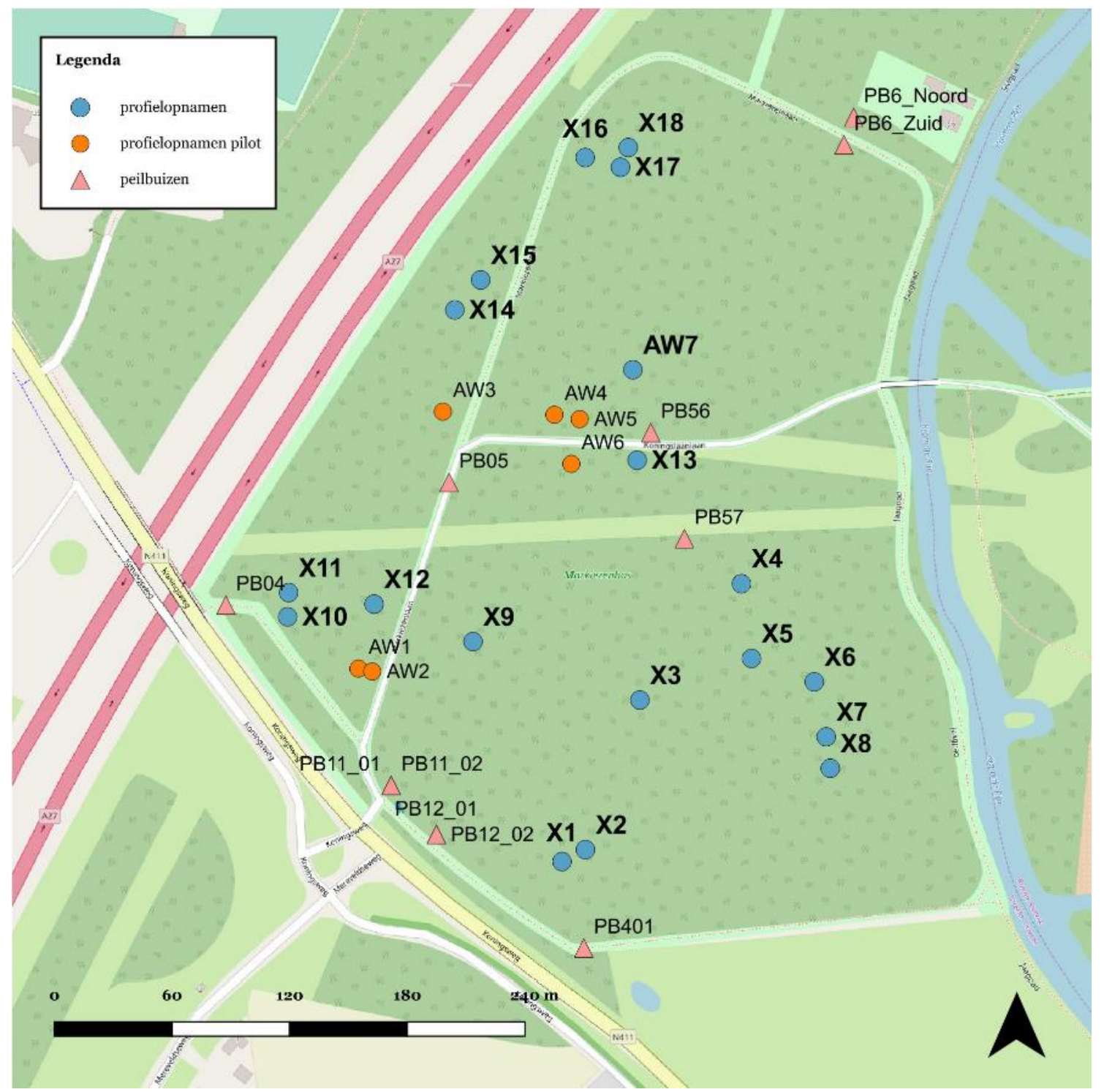

Figuur 1 Ligging van peilbuizen (driehoekjes) en geselecteerde bomen met profielopnamen uit de pilot (oranje) en aanvullende opnamen (blauw) in het Markiezenbos. Kaart ondergrond: Openstreetmap.org. 


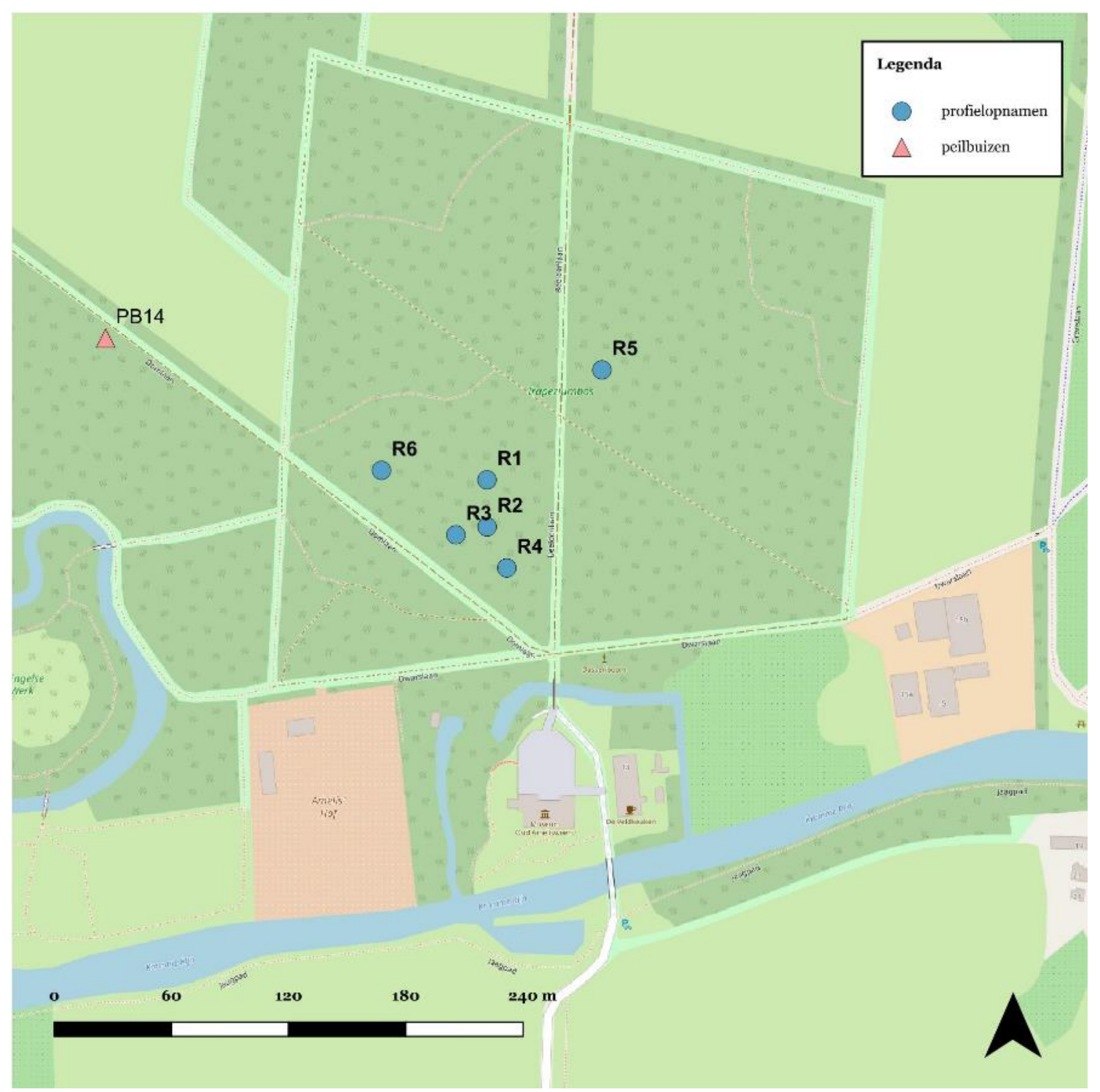

Figur 2 Ligging van peilbuizen (driehoekjes) en geselecteerde bomen met profielopnamen uit de pilot (oranje) en aanvullende opnamen (blauw) in het Trapeziumbos. Kaart ondergrond:

Openstreetmap.org.

In juli en augustus 2018 zijn 25 bomen in het Markiezenbos op Nieuw-Amelisweerd en 6 bomen in het Trapeziumbos op Oud-Amelisweerd geselecteerd voor nader onderzoek in het kader van het verdiepingsonderzoek. De posities van de geselecteerde bomen zijn weergegeven in Figuur 1 en Figuur 2.

Bij elke geselecteerde boom in het Markiezenbos is een profielkuil gegraven voor bodemkundig onderzoek. In het Trapeziumbos is de bodembeschrijving met behulp van de edelmanboor uitgevoerd, vanwege de kwetsbare stinzenbegroeiing, waardoor het niet mogelijk was hier met een graafmachine kuilen te graven. Alle bomen zijn beschreven op uiterlijke kenmerken en er zijn jaarringmonsters genomen om de groei van de bomen te analyseren.

De profielkuilen in het Markiezenbos zijn gegraven door een lange profielsleuf naar de boom toe te graven. Hiermee wordt een beeld te verkregen van de profielopbouw, de diepte en impact van het grondwater en de manier waarop de boom in deze omstandigheden wortelt. Het graafwerk is uitgevoerd met ondersteuning van een graafmachine. Hierbij is vanaf enkele meters afstand geleidelijk naar de boom toe gegraven. Zodra wortels zijn aangetroffen, is handmatig voorgestoken om schade aan dikkere wortels te voorkomen. In enkele gevallen zijn wortels recht met een handzaag afgezet om op dat punt nog wat verder te kunnen graven. Er is - afhankelijk van de soort en afmeting 
- niet te dicht op de boom gegraven om te voorkomen dat schades aan zwaardere (gestel)wortels ontstaan die later kunnen leiden tot aantastingen of een verminderde stabiliteit.

De hiermee verkregen informatie is in die zin niet volledig, omdat het ondergrondse deel van de boom slechts van één kant benaderd is. Daarnaast kon i.v.m. mogelijke schades niet gegraven worden in de zone direct rond de stamvoet waar bomen vaak intensief wortelen en tevens de zware hoofd- of gestelwortels de diepte in gaan en vertakken. Aangezien de bomen in een natuurlijke bossituatie als in Amelisweerd meestal vrij gelijkmatig in alle richtingen wortelen, wordt het met behulp van de profielsleuven verkregen beeld als representatief en geschikt beschouwd om hier verder conclusies uit te kunnen trekken.

\subsubsection{Bodembeschrijvingen}

De volgende gegevens zijn bij de profielkuilen en boringen beschreven of opgenomen:

- Coördinaten;

- Maaiveldligging (op basis van AHN2);

- Profielbeschrijving volgens Ten Cate et al. (1995);

- Foto's van de vegetatie en de kuil of boring;

- Kritieke z-afstand bodemprofielen bij een verticale flux van $2 \mathrm{~mm} / \mathrm{dag}$;

- $\mathrm{pH}$-profiel (niet in alle profielkuilen)

De bewortelbare diepte is op twee manieren opgenomen:

1. Tijdens de bodemprofielopname wordt een gestandaardiseerde bewortelbare diepte geschat op basis van profielkenmerken. Hierbij is de diepte bepaald waarop - gezien de kenmerken van de bodemlagen - beworteling mogelijk is. Daarvoor zijn fysische en chemische beperkingen als indringingsweerstand, waterverzadiging of zuurgraad bepalend. Of deze diepte ook benut wordt, hangt af van de bewortelingspatronen van het gewas. Omdat bomen over het algemeen dieper wortelen dan korte vegetaties zal de bewortelingsdiepte van bomen meestal overeenkomen met de bewortelbare diepte.

2. Door een uitgebreide beschrijving van het bewortelingsprofiel in de profielkuil als onderdeel van de vitaliteits- en groeibeoordeling van de boom. Deze bewortelingsdiepte (BEW) is in de profielkuil bepaald op basis van daadwerkelijk aangetroffen wortels in combinatie met de verwachting over de bewortelbaarheid van de bodemlagen. Omdat deze gebaseerd is op werkelijk waargenomen beworteling, wordt deze als betrouwbaarder gezien.

Om te bepalen of een vochttekort kan optreden bij dalende grondwaterstanden, wordt uitgegaan van de 'effectieve bewortelingsdiepte' (BEW-80). Dat is $80 \%$ van de bewortelbare diepte. Als de grondwaterstand dieper zakt dan de kritieke z-afstand onder deze diepte, kan onvoldoende opname door de wortels gegarandeerd worden. Als we ervan uitgaan dat de bomen de bewortelbare diepte optimaal benutten, kunnen we concluderen dat de waargenomen bewortelingsdiepte overeenkomt met de werkelijk bewortelbare diepte en dat we dus $80 \%$ van deze diepte moeten hanteren als effectieve bewortelingsdiepte.

De belangrijkste kenmerken van de profielen zijn opgenomen in een database, waarna met het softwarepakket 'Titanen' (Wesseling, in voorbereiding) de kritieke z-afstand (Zk) en vochtleverend vermogen zijn afgeleid. De kritieke $z$-afstand is de afstand tussen het grondwater en de onderkant van de effectieve wortelzone, waarover een flux van $2 \mathrm{~mm} /$ dag nog net mogelijk is. Deze is berekend op basis van het bodemprofiel (vertaald naar bouwstenen van de Staringreeks) en dus gebaseerd op algemene kenmerken, gemeten in standaard bodemfysische bodemmonsters. De Zk-waarden zijn dus niet berekend en getoetst aan de onderzochte profielen. Wanneer de afstand tussen de bewortelde zone en de actuele grondwaterstand groter wordt dan de berekende $Z k$, is de kans op verdroging reëel. 


\subsubsection{Beoordeling vitaliteit en groeiontwikkeling bomen in relatie tot bodem en beworteling}

Van elke boom binnen de onderzochte selectie zijn in het veld verschillende boomtechnische parameters opgenomen, waaronder afmetingen (stamdikte, boomhoogte, kroondiameter, hoogte van de onderste primaire en secundaire kroontakken of de conditie). Daarnaast is gekeken naar gebreken en aantastingen (of symptomen hiervan) die een rol zouden kunnen spelen bij de ontwikkeling van de boom. Uit al deze variabelen tezamen wordt de vitaliteit van de boom afgeleid.

Op basis van het huidige totaalbeeld zijn vervolgens conclusies getrokken wat betreft het functioneren van de boom in de laatste jaren tot enkele decennia. Hierbij is elke boom vanuit verschillende perspectieven benaderd:

- Voor de beoordeling van het vertakkingspatroon (vorm en lengte van eind- en zijscheuten van de laatste jaren, doorzet en continuïteit van de groei in de eerder aangelegde oudere takken) is gebruikgemaakt van de door de Duitse bosbotanicus A. Roloff geïntroduceerde beoordelingssystematiek (Roloff, 2001). Roloff maakt onderscheid tussen verschillende 'Vitalitätsstufen' die zich uiten in het kroonbeeld. Daarnaast beschrijft hij de wijze van doorgroei van zijscheuten na aanleg van de lengtescheut (reïteratie). Het gedeeltelijk of geheel uitblijven van deze doorgroei in delen van de kroon is een symptoom voor het afnemen of zelfs geheel stagneren van de ontwikkeling.

- Uit de vorm van de stam, de hoogte en de opbouw van de kroon kan worden afgelezen of een boom in zijn eerste levensfase ruimte had om zich ook in de breedte te ontwikkelen of hierin belemmerd werd door andere bomen van vergelijkbare of grotere afmetingen in de buurt.

- Directe overgangen van dikke, oudere takken naar veel jongere takken geven aan dat er tijdens de levenscyclus van de boom een fase was waarin takken zijn afgestorven of afgestoten. Een dergelijk beeld kan veroorzaakt zijn door aantastingen, schades of andere factoren. Hieronder kunnen ook verdroging of vernatting binnen de wortelzone vallen.

- De rol van een bosboom (dominant/heersend, subdominant/mede-heersend, ondergeschikt of onderstandig) binnen zijn directe omgeving is eveneens een factor die medebepalend is voor de groei. Per boom is daarom de rol beschreven die hij in de huidige situatie inneemt. Daarnaast staat vermeld wanneer vlak bij de onderzochte boom restanten (stobben) aanwezig waren van grotere exemplaren die in eerdere jaren een extra belemmering vormden met het oog op licht en ruimte.

- Tegelijk met de boombeoordeling zijn de wortelstelsels van de bomen beschreven (intensiteit, dikte, diepte en verdeling).

\subsubsection{Jaarringonderzoek}

De jaarringreeks van een boom bevat informatie over de leeftijd en de groeidynamiek van een boom. De gemiddelde breedte van de jaarringen zegt iets over het groeiniveau van een boom en de groeidynamiek beschrijft de veranderingen van de groeiactiviteit over de tijd. Het groeiniveau van een boom verandert geleidelijk met toenemende stamdiameter (leeftijdstrend); abrupte veranderingen van het groeiniveau (meerjarige groeidepressies of groeispurten) duiden op veranderingen in omgevingscondities (veranderingen in grondwaterstanden of vrijstelling) die invloed hebben op de algehele vitaliteit van de bomen. Daarnaast varieert de jaarringbreedte van jaar tot jaar, afhankelijk van jaarlijks wisselende groeiomstandigheden, die voornamelijk gelinkt zijn aan klimaatfactoren (bijvoorbeeld droge zomers). De invloed van klimaatfactoren (temperatuur, neerslag) varieert, afhankelijk van de specifieke standplaatscondities, maar ook tussen boomsoorten, afhankelijk van onder andere soort specifieke eigenschappen zoals tijdstip van uitlopen, wortel morfologie etc. Klimaat-groeirelaties van boomsoorten op een standplaats bevatten informatie over groei-limiterende klimaatfactoren. Deze informatie kan relevant zijn om de gevoeligheid van boomsoorten tegenover veranderingen in klimaatfactoren, maar ook standplaatsfactoren - in dit geval veranderingen in waterbeschikbaarheid - in te schatten.

\section{Monstername jaarringonderzoek}

Per boom zijn twee boorkernen met een aanwasboor (diameter $5 \mathrm{~mm}$ bemonsterd) op $130 \mathrm{~cm}$ stamhoogte (DBH) genomen. Omdat bepaling van leeftijd niet voornamelijk doel was, zijn boorkernen van maximaal $40 \mathrm{~cm}$ lengte genomen, waardoor dikke bomen niet tot het merg bemonsterd zijn. Voor 
dunnere bomen is een inschatting van de leeftijd gemaakt (zie Tabel 1). De boorkernen zijn in plastic rietjes opgeborgen en naar het lab getransporteerd.

\section{Monsterpreparatie}

Op het DendroLab van Wageningen Universiteit zijn de boorkeren uit de rietjes gehaald en in houten houders geplakt om kromtrekken tijdens het drogen te voorkomen. Vervolgens werd de kopse kant van de boorkernen met een microtoom oversneden om de jaarringen duidelijk zichtbaar te maken.

\section{Meten van jaarringen}

De jaarringbreedtes werden onder een binoculair (vergroting 10-40 maal) op een dendrochronologische meettafel (LINTAB, Rinntec) met een nauwkeurigheid van 1/100 mm opgemeten. De meetgegevens werden met behulp van het meet- en analyseprogramma WinTSAP bewerkt. De jaarringreeksen zijn per boomsoort visueel en statistisch onderling vergeleken (kruisdateren) om voor mogelijke meetfouten te corrigeren en elke jaarringbreedte exact te koppelen aan een kalenderjaar.

\section{Leeftijdsbepaling}

Voor bomen met een diameter van maximaal $75 \mathrm{~cm}$ (max. boorkernlengte $40 \mathrm{~cm}$ ) is een inschatting gemaakt van de leeftijd. Daarbij is het feit meegenomen dat (1) het merg niet altijd aanwezig was op de boorkern en de eerst gevormde jaarringen ontbraken en (2) het monster op $130 \mathrm{~cm}$ is genomen, wat betekent dat een onbekend aantal jaarringen ontbreekt (tijd tot de boom op $130 \mathrm{~cm}$ hoogte gegroeid was).

\section{Analyse groeipatronen}

Er zijn grafieken op gelijke schaal gemaakt van de groeipatronen van alle geanalyseerde bomen. Voor de illustratie zijn de groeireeksen van de twee gemeten radii per boom (twee boorkernen) gemiddeld. De gemiddelde jaarringbreedte met standaardafwijking is in een tabel weergegeven.

Voor de vergelijking van gemiddelde groeipatronen van beuk, eik en es in het Markiezenbos en het Trapeziumbos (referentie), maar ook ter vergelijking van gemiddelde groeipatronen tussen de drie soorten, zijn eerst middelcurves uit respectievelijk ruwe jaarringreeksen en gestandaardiseerde jaarringreeksen berekend. Standaardisering van jaarringreeksen houdt in dat boom-individuele trends (zoals de leeftijdstrend) statistisch uit de jaarringreeks worden verwijderd door de aanpassing van een statistische functie (spline-functie met lengte 30 jaar). Bij deze standaardprocedure wordt de laagfrequente variatie uit de curves verwijderd en de resulterende jaarringreeksen (= jaarringindexen) hebben alle dezelfde middelwaarde en dezelfde variatie. Deze jaarringindexen worden in het vervolg gemiddeld tot een indexmiddelcurve. De indexmiddelcurves worden gebruikt voor het berekenen van klimaat-groeirelaties (response-functies). Daarvoor wordt de indexmiddelcurve vergeleken met maandelijkse neerslag- en temperatuurgegevens van het weerstation De Bilt (KNMI, Climate Explorer). In dit onderzoek is gekeken naar de invloed van neerslag en temperatuur van zomer vorige jaar (juni) tot het einde van de actuele groeiperiode (september). De gebruikte methode is een bootstrap-regressiemodel. Alle analyses zijn uitgevoerd met het programma R (R Core Team, 2018; package $d p / R$; Bunn, 2008). 


\section{Resultaten}

\section{$3.1 \quad$ Bodem}

Uit de profielbeschrijvingen zijn een aantal algemene conclusies te trekken. De bodembeschrijvingen per profielkuil zijn gegeven in bijlage 1 .

In het algemeen is de profielopbouw vanaf maaiveld een overgang van lichte klei in de bovengrond naar zware klei in de ondergrond, waaronder weer een zandlaag ligt. De bovengrondtextuur kan verschillen van zware zavel tot zware klei, met een enkele ophoging of bijmenging met zand aan maaiveld. De kleilagen waren op sommige locaties zo zwaar en compact dat het zelfs met een graafmachine moeilijk was om de grond laagsgewijs naar de diepte toe af te schrapen.

De zwaardere kleilaag kan zeer stagnerend werken voor vocht/regenwater van bovenaf, maar ook een belemmering zijn voor de wortels. Deze zwaardere kleilaag is niet overal duidelijk aangetroffen. In kuilen die op kleine afstand (soms minder dan $20 \mathrm{~m}$ ) van elkaar liggen, komt een relatief grote variatie voor in de begin- en einddiepte van de verschillende textuurlagen. Hieruit moet worden vastgesteld dat de bodemopbouw in Amelisweerd op kleine schaal een grote variatie vertoont. De overgang van klei naar zand was in de profielkuilen niet altijd horizontaal gelaagd, maar soms ook scheef gesteld.

In de meeste profielen is (grof) zand in de ondergrond aangetroffen, behalve in de profielkuilen X4, $\mathrm{X} 10, \mathrm{X} 11$ en X14. Soms is de zandlaag leemhoudend. De begindiepte van de zandlaag varieert sterk, van $72 \mathrm{~cm}-\mathrm{mv}$ tot $180 \mathrm{~cm}-\mathrm{mv}$. Gemiddeld ligt de begindiepte van de zandlaag in het Trapeziumbos dieper (146 cm-mv) dan in het Markiezenbos (105 cm-mv). De diepte waarop de kalkhoudende laag zich bevindt, varieert $20 \mathrm{~cm}-\mathrm{mv}$ tot dieper dan de onderkant van de profielkuil.

De beworteling lijkt zich vooral in de ondiepere, minder zware kleilagen te concentreren, hoewel er ook diepere wortels in de zware klei voorkomen, maar met een kleinere dichtheid. Waar het zand begint, is meestal ook het einde van de bewortelbare diepte. Niet helemaal duidelijk is hoeveel wortels tot onder aan de kleilaag (geschatte bewortelingsdiepte) komen en of daarmee de vochtvoorziening bij diepere grondwaterstanden gewaarborgd is. Hierover volgt meer in § 3.2.

De waarden voor de bewortelingsdiepte BEW-80 en BEW verschillen in een paar gevallen aanzienlijk, maar meestal zijn ze wel in dezelfde orde van grootte geschat (Figuur 3). Het verschil tussen beide waarnemingen kan oplopen tot wel $50 \mathrm{~cm}$. Meestal gaat het dan om waarnemingen waarbij de waargenomen beworteling ondieper is dan de geschatte diepte.

Bij de geschiktheidsbeoordeling voor bosbouw (Ten Cate et al., 1995D) wordt het vochtleverend vermogen van de bodem bepaald op basis van de LG3 (het gemiddelde van de drie laagste grondwaterstanden) in een $10 \%$ droog jaar. Dat is 20 tot $40 \mathrm{~cm}$ onder de GLG. Deze diepte moet dan vergeleken worden met de kritieke grondwaterdiepte (BEW-80 + Zk). De kritieke z-afstand (Zk) varieert sterk met de profielopbouw en de diepte van de GLG. Het Markiezenbos heeft gemiddeld een grotere kritieke z-afstand dan het Trapeziumbos (respectievelijk 115 en $67 \mathrm{~cm}$ ). De gemeten grondwaterstanden liggen door de zeer droge zomer onder de geschatte GLG, overeenkomstig de LG3 in een $10 \%$ droog jaar. Daarom kunnen de metingen van deze zomer gebruikt worden om te bepalen of in de huidige situatie een potentieel vochttekort kan voorkomen. Bij een ingreep zoals een bronbemaling moet dan bekeken worden of de grondwaterstanden die daarbij verwacht worden onder de kritische diepte zullen zakken.

Bij het huidige grondwaterstandverloop en de waargenomen bewortelingsdiepte is op dit moment op veel plaatsen sprake van een grondwaterprofiel waarbij gedurende het hele groeiseizoen voldoende vocht beschikbaar is. In een beperkt aantal gevallen zal sprake zijn van een tijdelijk grondwaterprofiel, waarbij in het voorjaar nog ruim voldoende bodemvocht beschikbaar is uit capillaire nalevering, maar waarbij deze bijdrage in de loop van de zomer zal afnemen en stoppen bij een daling van de grondwaterstanden. 
De Zk-waarden zijn berekend op basis van het bodemprofiel (vertaald naar bouwstenen van de Staringreeks) en dus gebaseerd op algemene kenmerken uit bodemfysische metingen in monsters uit andere gebieden met dezelfde textuur. De $\mathrm{Zk}$ is hier bepaald bij een capillaire naleveringsflux van $2 \mathrm{~mm} /$ dag. Dit is een flux waarbij de meeste vegetaties geen droogteschade ondervinden. Als het grondwater dieper komt dan wortelzone $+Z \mathrm{k}$, hoeft de nalevering niet helemaal weg te vallen, maar kan er nog steeds een kleinere flux plaatsvinden (bv. $1 \mathrm{~mm} / \mathrm{dag}$ ) waarbij de droogteschade meevalt. In het algemeen wordt de Zk bij $2 \mathrm{~mm} / \mathrm{dag}$ wel aangehouden als grens voor het optreden van droogteschade (Ten Cate et al., 1995D). Omdat niet goed duidelijk is hoe de beworteling onder de kleilaag is, is het goed mogelijk dat bij een diepere grondwaterstand (als gevolg van bemaling) het contact van de capillaire nalevering verbroken wordt en tijdelijk minder vocht beschikbaar komt voor de bomen.

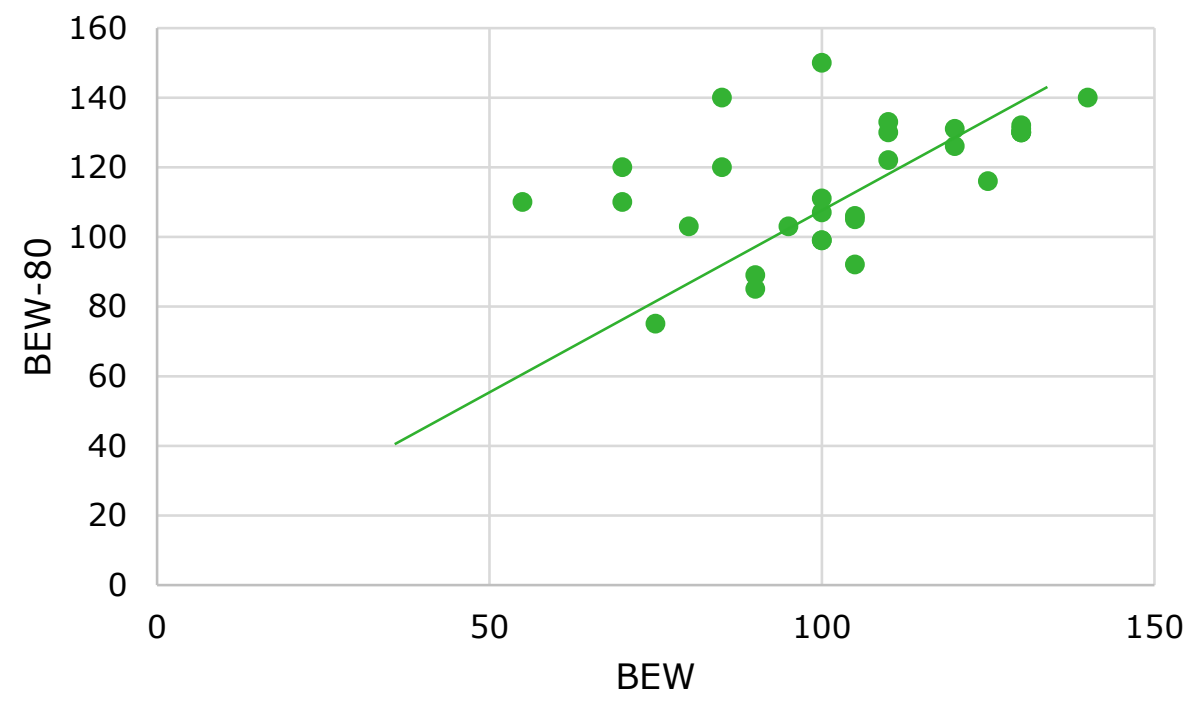

Figuur 3 Geschatte bewortelbare diepte BEW-80 uitgezet tegen de waargenomen bewortelingsdiepte BEW. Naarmate de punten verder afliggen van de geplotte lijn, zijn de verschillen tussen de beide waarnemingen bij een boom groter.

\subsection{Conditie en groeiontwikkeling onderzochte bomen}

\subsubsection{Algemeen conditiebeeld}

De meeste onderzochte bomen vallen qua conditie binnen de categorieën goed en voldoende. Slechts enkele exemplaren zijn ingedeeld binnen de categorie matig. Aangezien er enkele exemplaren zijn waar het conditiebeeld onderin en in het midden van de kroon anders is dan in de bovenkroon, is er in die gevallen voor gekozen om met een tussencategorie (voldoende tot matig) te werken.

Dit conditiebeeld is representatief voor grote delen van de onderzochte zones binnen het onderzochte Markiezenbos en het Trapeziumbos. 

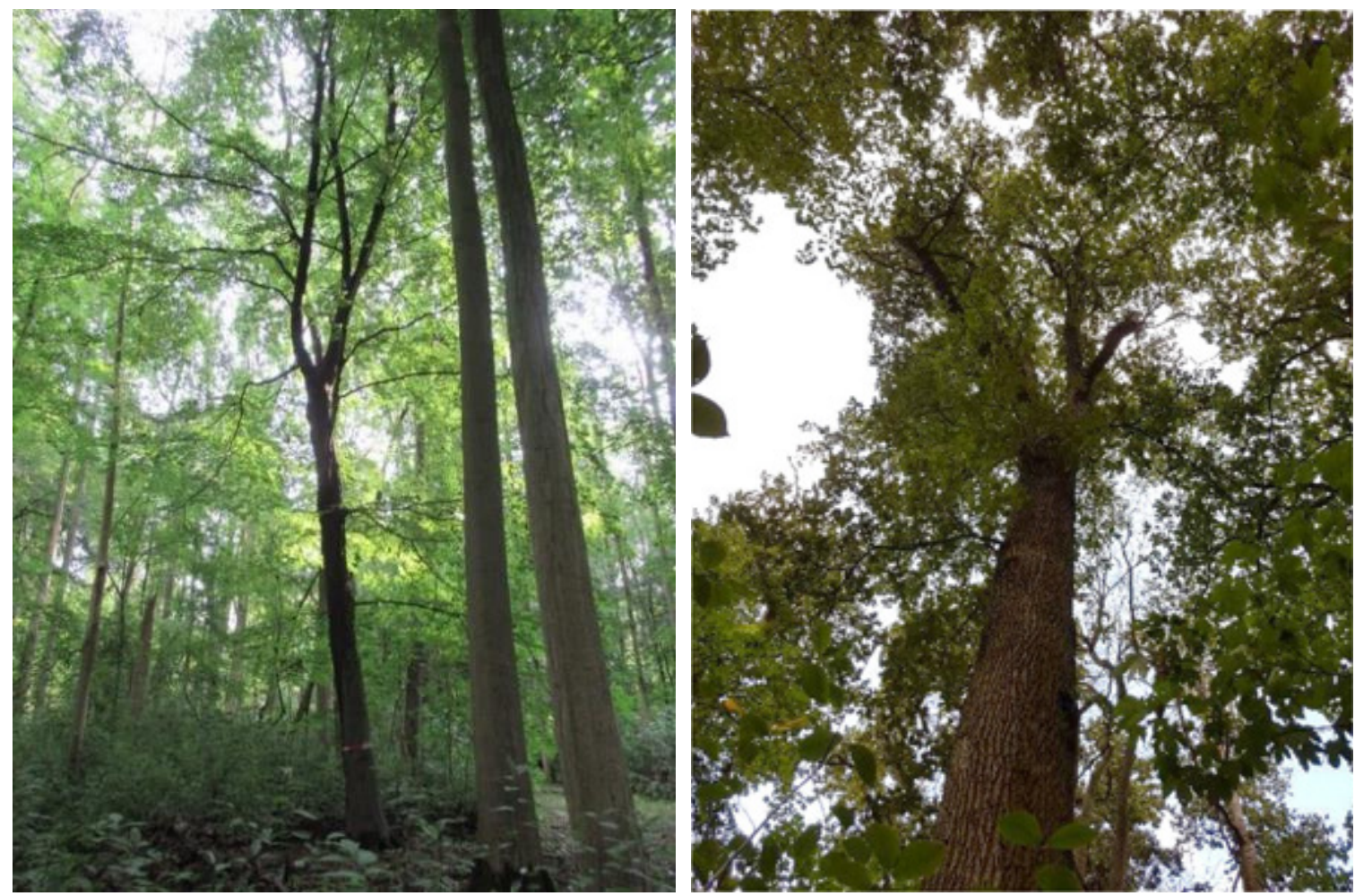

Foto 1 Links: Jonge beuk met goede groei en conditie (boom 4). Rechts: Bij deze zware eik (boom 15) is de conditie voldoende tot matig. De boom is niet in staat om met zijn kroon de beschikbare ruimte volledig te benutten, wat mede samenhangt met in het verleden uitgebroken hoofdtakken.

Bomen met een ziekte of aantasting zijn in dit onderzoek niet meegenomen. In de bossen van Amelisweerd betreft dit voornamelijk essen die aangetast zijn door de essentaksterfte. Deze ziekte heeft in Amelisweerd in de laatste jaren haar tol geëist en er zullen hierdoor ook in de komende jaren nog essen afsterven. De ziekteverschijnselen doen zich verspreid over het hele bos voor. Aangezien essen van alle leeftijden en conditieklassen (kunnen) worden aangetast door de essentaksterfte en het uit de ziekte resulterende slechte huidige conditiebeeld niet representatief is voor de relatie tussen de groeiplaatsomstandigheden en de ontwikkeling van de boom, zijn aangetaste essen niet meegenomen in dit onderzoek.

\subsubsection{Kroonontwikkeling in relatie tot omgevingsfactoren}

In een samenhangend en hoog opgaand bos als het Markiezenbos en het Trapeziumbos hangt de groeiontwikkeling van bomen in sterke mate af van de beschikbaarheid van licht en ruimte.

Wanneer bomen van dezelfde leeftijd op korte onderlinge afstanden opgroeien, vindt de meeste groei in de bovenkroon plaats. Een boom reageert op de lichtinval in het bovenste deel van het kronendak en investeert daarom qua groei vooral in lange topscheuten. De groei en verdere ontwikkeling van zijtakken blijven beperkt. Door de snelle en gelijktijdige hoogtegroei van alle bomen in de omgeving worden de zijtakken tevens snel minder productief (afnemende lichtinval). Als gevolg hiervan worden ze tijdens de eerste levensfase meestal snel weer afgestoten. Dit resulteert uiteindelijk in bomen met een vrij smalle en hoog aangezette kroon en in lange en gladde stammen.

Voor alle drie onderzochte boomsoorten kunnen bomen met een dergelijke vorm worden aangewezen. Wat de eiken betreft, is de situatie wel iets anders dan bij de beuken en essen. In Amelisweerd zijn geen zones met dichte opstanden met daarin veel zomereik. De 'jongere' eiken in het samenhangende bos zijn gemiddeld ouder dan de beuken en essen. Dit bleek al bij de selectie van bomen voor het onderzoek en werd bevestigd door de jaarringanalyse: zelfs de kleinere en slankere eiken binnen het bos hebben leeftijden van meer dan 100 jaar en zijn hiermee veel ouder dan de bomen van andere soorten eromheen (zie § 3.3). 
Bij de eiken doet zich nog een ander verschil voor. Ook op latere leeftijd lopen eiken op de stam en op de gesteltakken nog uit wanneer deze door omstandigheden meer aan het licht geëxponeerd raken. Het stamlot dat dan vanuit slapende knoppen ontstaat, is qua dimensie heel anders dan het dikhout waarop het zit. Voor de boom levert het wel een stuk extra fotosynthese op en sommige eiken kunnen binnen een proces van decennia zelfs een nieuwe kroon vanuit deze secundaire scheutgroei ontwikkelen.

De beuk heeft als bosboom het vermogen om ook bij een verminderde lichtinval (halfschaduw) nog productief te zijn met zijn bladeren. Waar het kronendak niet geheel samenhangend en gesloten is, ontwikkelen beuken daarom zijtakken die met de verdere ontwikkeling van de boom meegroeien. Op het moment dat een beuk nog meer licht ruimte ter beschikking heeft, ontwikkelt hij zijn kroon ook in de breedte. Hoe meer licht en ruimte, hoe zwaarder de zijtakken worden. Enkele exemplaren lukt het dan om een volledig uitgegroeide brede kroon met zware gesteltakken te ontwikkelen. In het Markiezenbos en het Trapeziumbos van Amelisweerd staan veel beuken die zich zo hebben ontwikkeld tot dominante bomen binnen hun directe omgeving. Bij diverse exemplaren zitten nog lange en wat dikkere takken beneden de aanzet van de zware hoofdtakken of gesteltakken. Hieruit kunnen conclusies getrokken worden wat betreft de ontwikkeling door de jaren heen. De daadwerkelijke zware kroon is dan pas aangelegd op het moment dat de beuk de ruimte hiervoor had, maar de breedtegroei is al op een eerder moment begonnen.

Bij sommige van de oude en zware eiken doet zich een vergelijkbaar beeld voor. Deze hebben op een bepaald moment een brede en vol ontwikkelde kroon gevormd. Deze kronen zijn doorgaans vrij hoog aangezet (vaak op twee derde van de totale boomhoogte). De zijtakken onder deze kroonaanzet zijn daarna meestal afgestoten. Het vormen van doodhout door het afsterven van takken die onder in de kroon raken en minder productief worden, is bij eik een natuurlijk proces dat niet gerelateerd is aan de conditie of het functioneren van de boom.
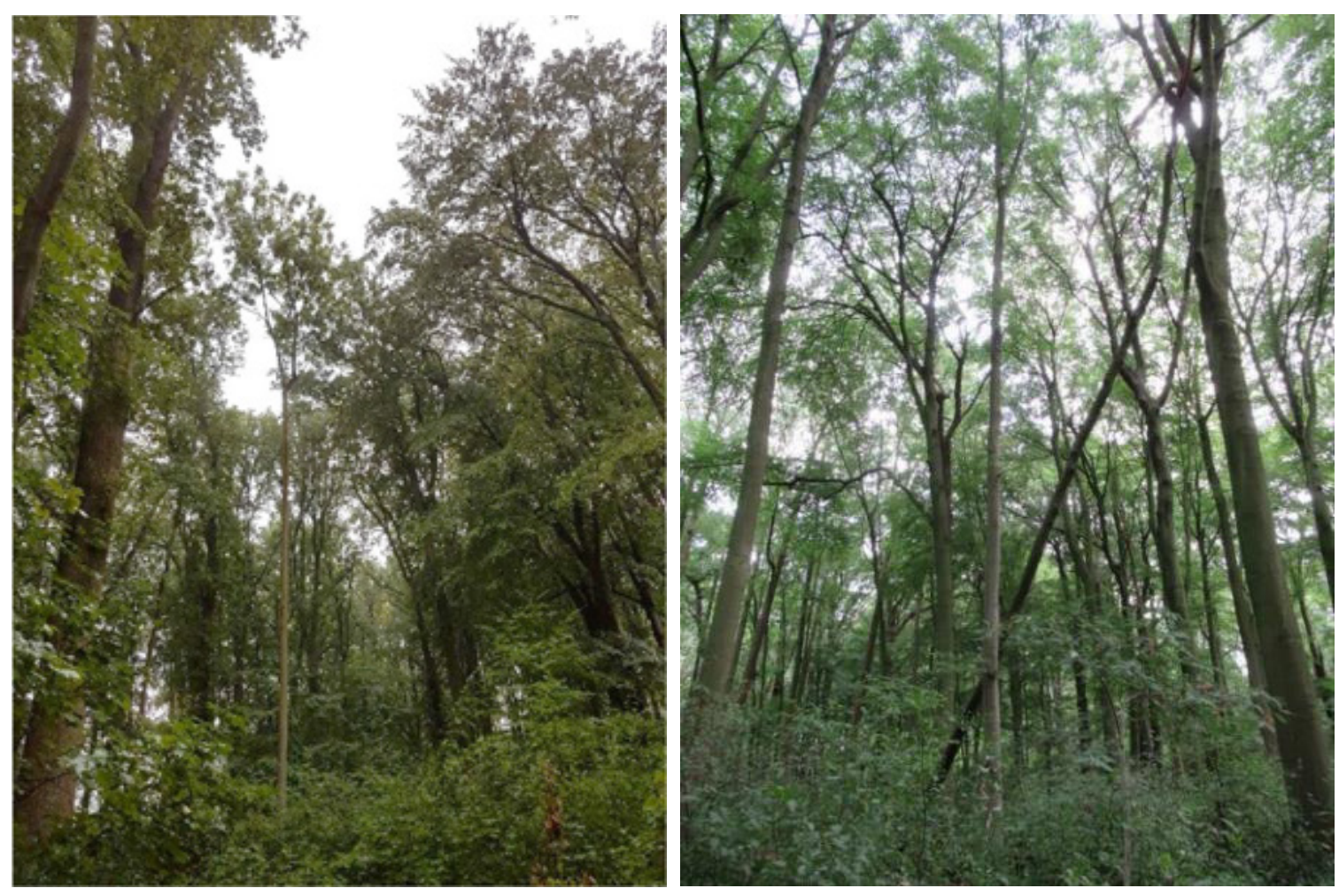

Foto 2 Voorbeelden voor es (links, boom R6) en beuk (rechts, boom nr. 9) met kleine en hoog aangezette kronen en zeer slanke en takvrije stammen. De es op de linkerfoto heeft pas recentelijk meer ruimte ter beschikking gekregen doordat hier enkele grotere beuken en eiken zijn weggevallen. 

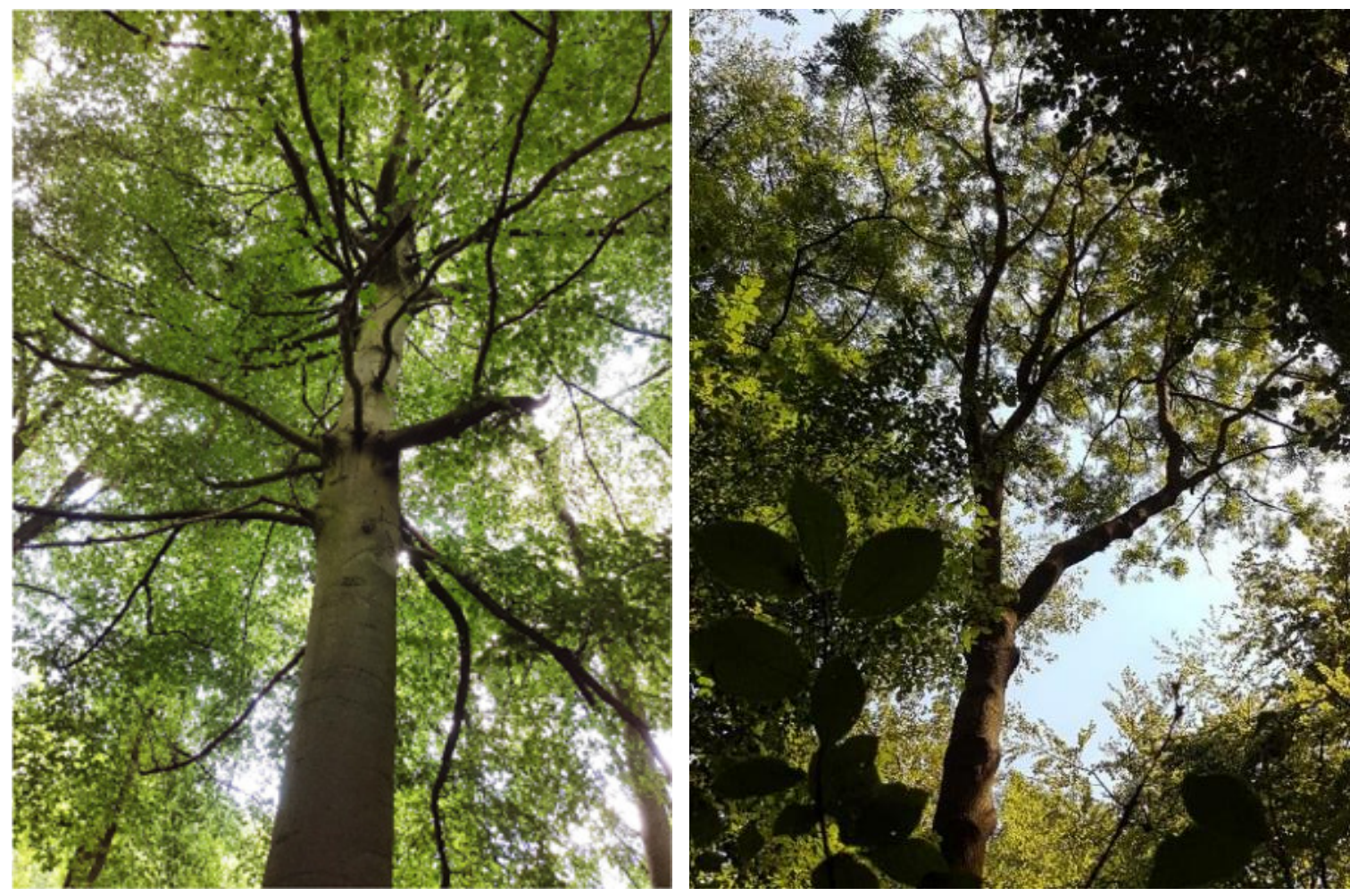

Foto 3 Links: vol uitgegroeide beuk met een breed ontwikkelde kroon (boom AW4). De zwaarste kroontakken (gesteltakken) zitten hoger dan diverse breed uitgaande takken in de onderkroon. Rechts: volwassen es (boom AW5) met een vrij breed ontwikkelde kroon en enkele zware gesteltakken. Op de stam zijn verdikkingen te zien. Dit zijn zones waar de boom takken heeft afgestoten (breuk na afsterven) en die inmiddels volledig overgroeid zijn.

Ook enkele essen hebben een wat bredere en zwaardere kroon ontwikkeld. Bij deze bomen zijn op de stammen meestal nog de verdikkingen te zien die ontstaan zijn door het overgroeien van het breukvlak van eerder afgestorven en uitgebroken zijtakken.

\subsubsection{Beworteling}

Uit de beoordeling van de beworteling in relatie tot de profielbouw van de bodem bij de 30 onderzochte bomen komen diverse aspecten naar voren. De maximaal bereikte worteldiepte varieert per locatie en boomsoort. Opvallend is de spreiding van de worteldiepten bij de drie soorten (zie Figuur 3 en bijlage 1). Dit is mede te verklaren door het feit dat bij enkele eiken een relatief ondiepe zware (storende) kleilaag is aangetroffen. Nog opvallender is echter dat de gemiddelde worteldiepte bij de 10 onderzochte eiken met gemiddeld ca. $93 \mathrm{~cm}$ het geringst is van de drie onderzochte boomsoorten en beuk gemiddeld het diepst wortelt (ca. $112 \mathrm{~cm}$ ). Beuk heeft als hartwortelaar normaal gesproken de minst diepe beworteling.

Bij nagenoeg alle onderzochte bomen was het bovenste deel van het bodemprofiel (zeer) intensief doorworteld. Hier is de klei onafhankelijk van de kleur en samenstelling goed gerijpt en ontwikkeld. Er is sprake van biologische activiteit (onder andere door regenwormen) en een bodem met een goede kruimelige structuur met stabiele aggregaten.

Bij bomen waar de zware storende kleilaag laag ondiep is aangetroffen, kan deze mede verantwoordelijk zijn voor een matige ontwikkeling en groei van de betreffende boom. Dat geldt bijvoorbeeld voor de eiken nr. 3 en nr. 14, die allebei een zeer geringe gemiddelde jaarringdikte laten zien (zie § 3.3). 


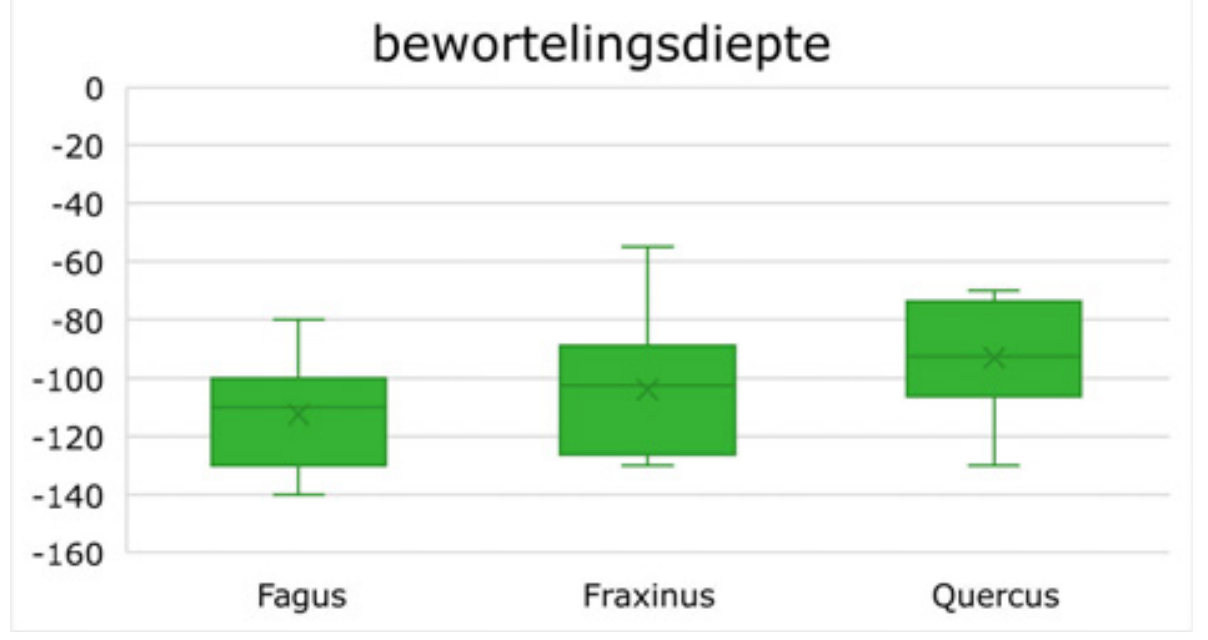

Figuur 4 Bewortelingsdiepte van de bemonsterde beuk, gewone es en zomereik. De groene boxen geven de $95 \%$ interval, het kruisje is de gemiddelde waarden, de horizontale lijn geeft de mediaan en de verticale staafje geven de minimum- en maximumwaarden aan.

\subsubsection{Aantastingen en veranderende omgevingsfactoren}

Binnen de levenscyclus van een boom kunnen zich incidenten voordoen die een tijdelijk of permanent effect hebben op de verdere groei en ontwikkeling. Hieronder vallen ziektes en aantastingen die afhankelijk van de aard hiervan - leiden tot schade aan de organen van de boom als bladeren, haarwortels of het cambium.

Daarnaast kunnen in de directe omgeving van de boom veranderingen plaatsvinden waardoor de groeiomstandigheden verbeteren of verslechteren. Hierbij valt de denken aan het wegvallen van bomen in de nabijheid waardoor er (tijdelijk) meer licht en ruimte beschikbaar komt. Vallende grote bomen kunnen anderzijds weer mechanische schade aan andere bomen veroorzaken waardoor in het vervolg een tijdelijke groeiachterstand kan ontstaan.

In de onderzochte zones van het Markiezenbos en het Trapeziumbos doen zich dergelijke ontwikkelingen en incidenten regelmatig voor:

- Bij diverse bomen is geconstateerd dat er een houtparasitaire schimmel aanwezig is of was. In veel gevallen ging het daarbij om een soort van de honingzwam: de gewone honingzwam (Armillaria mellea) of de sombere honingzwam (Armillaria ostoyae). Enkele oudere bomen lijken een eerdere aantasting door een van deze zwammen te hebben overwonnen.

- In verschillende bodemprofielen zijn daarnaast op enige afstand van de onderzochte boom rhizomorfen (zwarte draden) van de honingzwam gevonden. Mogelijk betreft dit rhizomorfen die gevormd zijn op stukken hout of wortels die afkomstig zijn van de restanten van bomen die er eerder stonden. De infectiedruk lijkt wat betreft de honingzwam wel hoog in Amelisweerd.

- De dynamiek van een bos brengt met zich mee dat er regelmatig bomen dood gaan. De oorzaken hiervoor kunnen veelvuldig zijn. In de afgelopen jaren zijn veel essen gekapt die aangetast waren door de essentaksterfte. De iep komt in het Markiezenbos nog als jonge boom of zaailing voor, maar de oudere iepen die er stonden, zijn in de afgelopen jaren bijna allemaal ten prooi gevallen aan de iepziekte. Op veel plaatsen zijn stobben van middelgrote en grote beuken en eiken aangetroffen. De oorzaak voor deze kap kon niet direct achterhaald worden. Het wegvallen van grotere bomen kan wel veel effect hebben op de bomen eromheen die opeens in een andere lichtsituatie terechtkomen en op dat moment vaak de kans krijgen om qua hoogte en breedte nog een stuk door te groeien.

- Grote bomen met aantastingen worden niet in alle gevallen geveld. Wanneer een dergelijk exemplaar in het bos omvalt, ontstaat niet alleen meer ruimte voor de andere bomen, maar worden door de vallende boom vaak takken en soms hele kroondelen afgescheurd. Daarnaast kan mechanische schade aan de schors/bast en aan ondiepe zware wortels of wortelaanzetten ontstaan. Een dergelijke klap kan een boom qua groei en ontwikkeling enkele jaren belemmeren voordat het oorspronkelijke 
kroonvolume hersteld is en het kan zelfs gebeuren dat een boom na een schade zijn oorspronkelijke kwaliteit en positie niet meer terugwint.
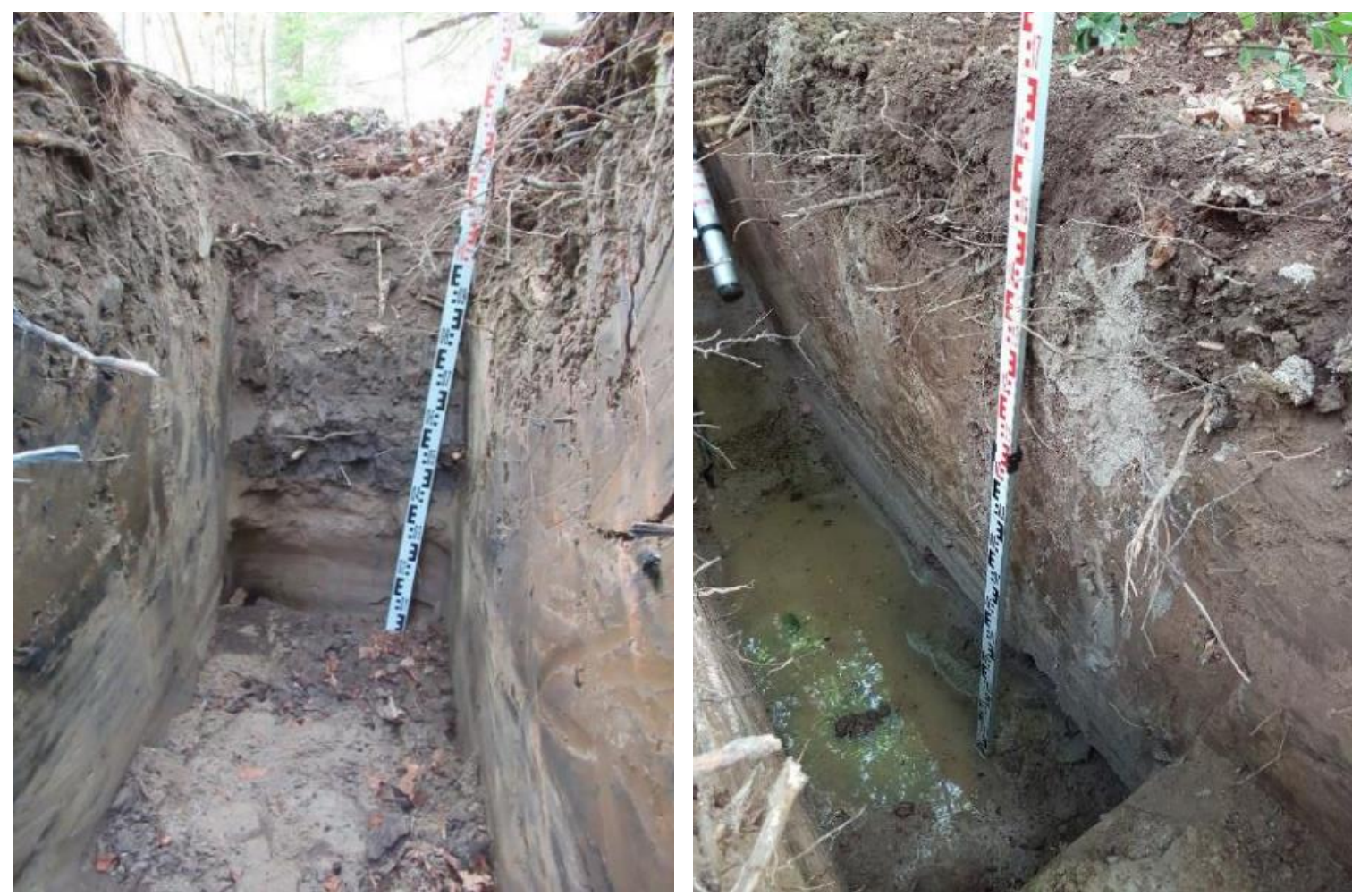

Foto 4 Links: profielsleuf bij boom nr. 2 (zware eik). De overgang van de lossere en goed doorwortelde bovengrond naar de compactere kleilaag (versmering rand door bak graafmachine) is goed zichtbaar. Rechts: de grote beuk nr. AW4 wortelt zeer goed en regelmatig in het bovenste gedeelte van het bodemprofiel. Deze boom heeft echter ook naar de diepte toe nog enige wortels in de compactere kleilagen kunnen vormen. 

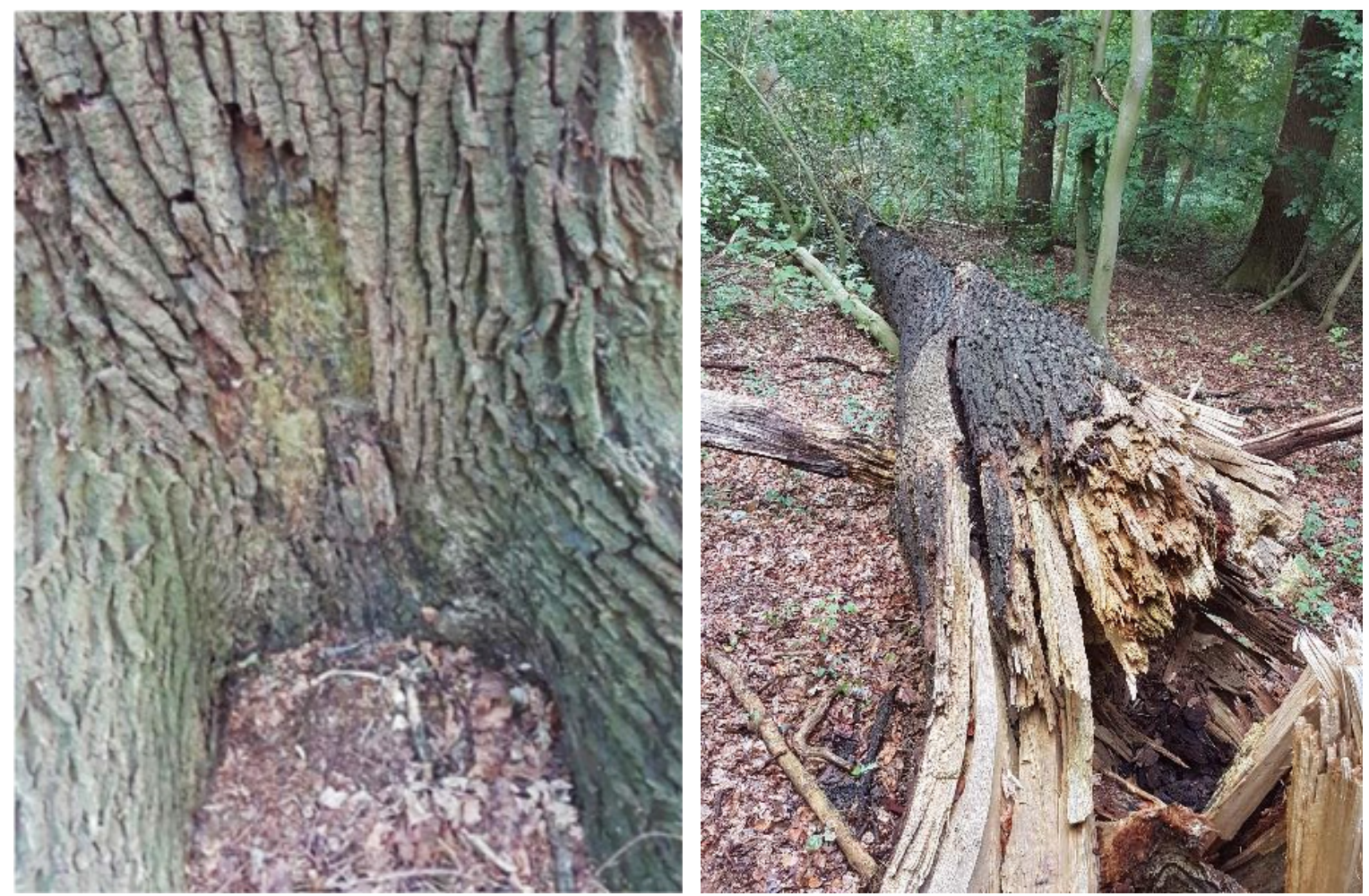

Foto 5 Links: de vorm en het schorspatroon tussen de wortelaanlopen van de grote eik AW2 duiden op een eerdere aantasting door de honingzwam die al enkele decennia terug ligt en door de boom in de tussentijd overwonnen is. Rechts: zware bomen die binnen het bos omvallen, zoals deze eik, zorgen voor meer licht en ruimte voor de ontwikkeling van andere bomen eromheen. De vallende bomen kunnen echter ook mechanische schades aan de kronen, stammen of wortelaanlopen van buurtbomen veroorzaken.

\subsection{Groei op basis van jaarringanalyse}

\subsubsection{Groeipatronen van de individuele bomen}

De groeipatronen van alle 30 geanalyseerde bomen zijn per standplaats (Markiezenbos, Trapeziumbos) en soort (beuk, eik, es) in bijlage 3 geïllustreerd. Alle afbeeldingen zijn voorzien van een gelijke schaal om directe vergelijking tussen bomen mogelijk te maken. Tevens zijn de jaarringreeksen van alle bomen schematisch op de kaart van het Markiezenbos en Trapeziumbos gezet om mogelijke ruimtelijke trends in jaarringpatronen te illustreren (Figuur 4 en Figuur 5). Tabel 1 omvat een overzicht van de gemiddelde groei per boom. 


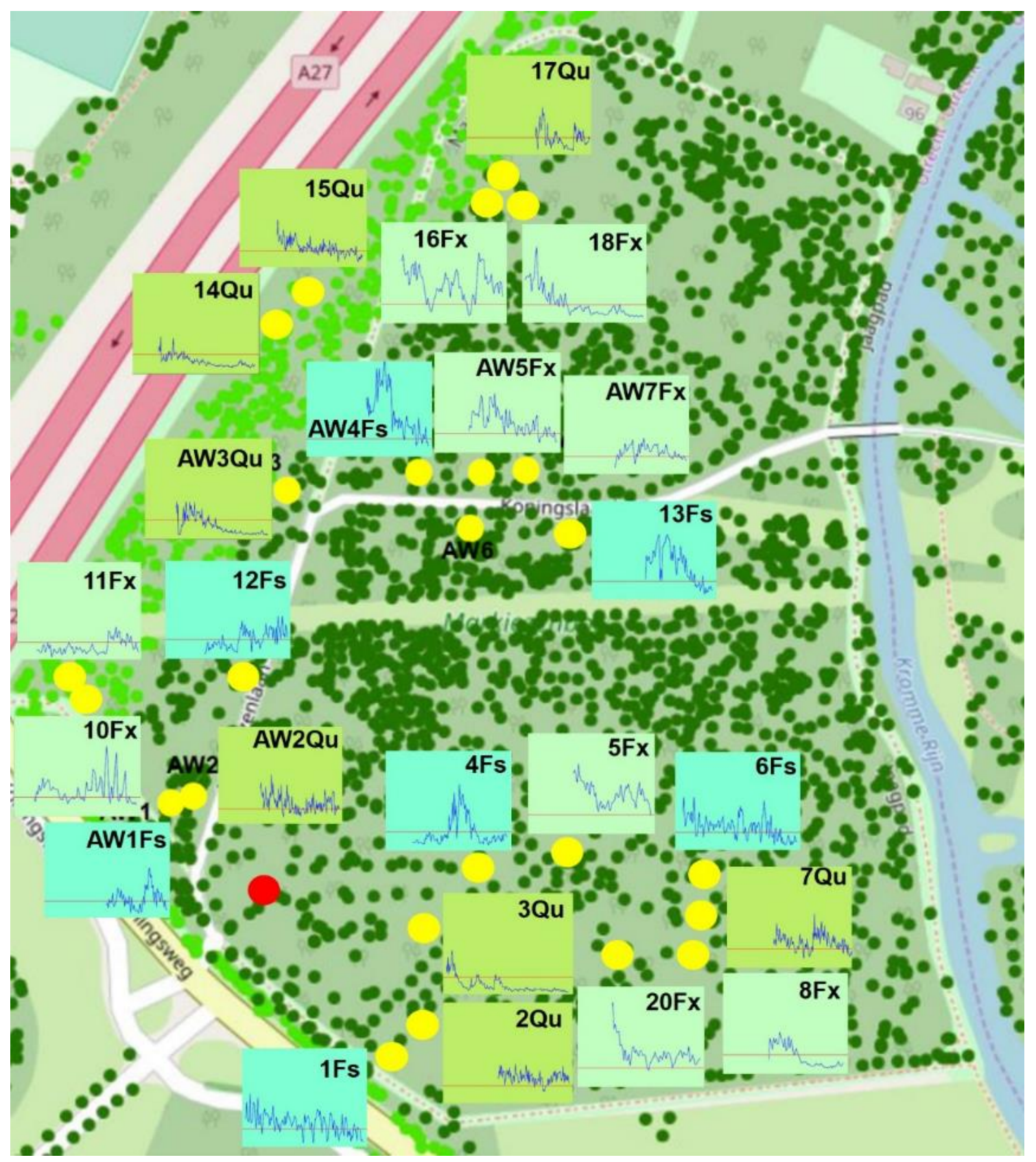

Figuur 5 Jaarringpatronen van 18 bomen in het Markiezenbos, Amelisweerd $(F x=e s, F S=b e u k$, $Q u=e i k)$; bron kaart: Pilot verdiepingsslag vitaliteit bomen i.r.t. bodem en grondwater. 


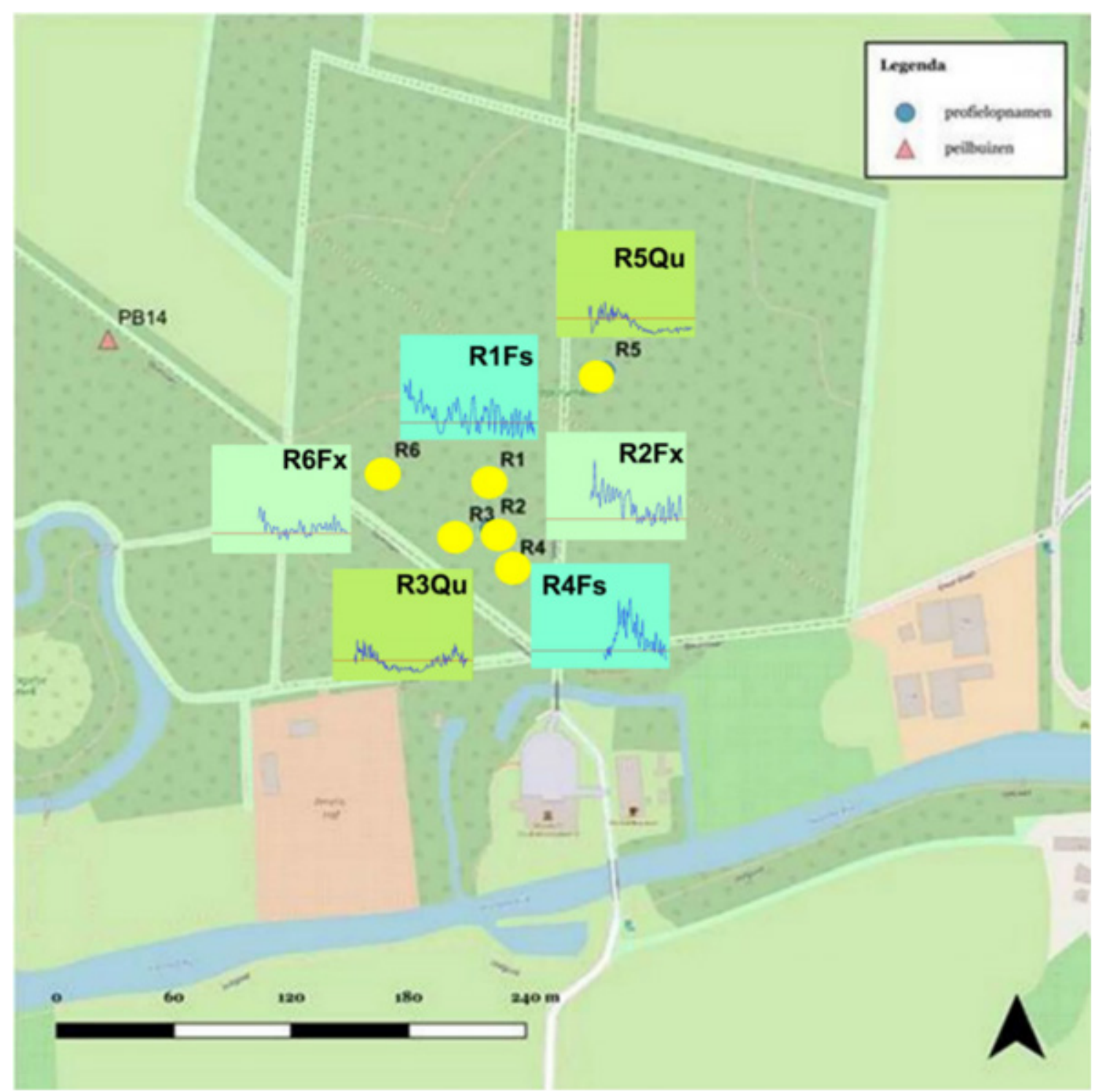

Figuur 6 Jaarringpatronen van 6 bomen in het Trapeziumbos (referentie), Amelisweerd (Fx=es, $F S=b e u k, Q u=e i k)$.

Uit de figuren is duidelijk dat de groeipatronen zowel tussen soorten, maar ook binnen de drie soorten sterk variëren. Dit betreft vooral de gemiddelde groeisnelheid en de langetermijnvariatie (groeitrends). Zoals eerder beschreven, zijn deze groeitrends gedeeltelijk beïnvloed door de leeftijd van de bomen. Met name de oudere eiken (AW2Q, 3Qu, 14Qu, 15Qu, R5Qu), maar ook essen (18Fx, R6Fx, AW5Fx) laten een sterke leeftijdstrend zien die een negatief exponentiële curve volgt. De beuken zijn variabeler wat betreft trends, wat mogelijk gelinkt is aan de schaduwtolerantie van beuk. Gemiddeld gezien is het groeiniveau van de eiken, die tevens de oudste boompopulatie vormen, het laagst, zeker in de afgelopen decennia. Met inachtneming van de langjarige trends in de jaarringcurves zijn er bij de bomen van alle drie soorten geen aanwijzingen voor een recente reductie in groeiactiviteit. Ook bomen die een laag groeiniveau vertonen gedurende de laatste tien jaar anticiperen in hun groei nog op jaren met betere condities. Alleen boom 3Qu en 10Fx laten gedurende de laatste jaren een zeer langzame en dalende groei zien.

Uit de jaarringreeksen van de afzonderlijke bomen van eik, es en beuk zijn geen consistente groeidepressies in het begin van de jaren 80 (aanleg van de A27) en eind jaren 90 (aanpassing grondwaterstanden) af te lezen. De meeste bomen laten tevens geen langdurige recente groeidepressie zien die kan duiden op aftakeling en bijzondere gevoeligheid voor toekomstige veranderingen in omgevingscondities. 


\subsubsection{Boomsoort specifieke groeipatronen: vergelijking groei tussen Markiezenbos en Trapeziumbos en tussen boomsoorten}

Vervolgens werden de jaarringreeksen van de bomen uit het Markiezenbos vergeleken met die van het Trapeziumbos, het referentiebos waarvan verondersteld wordt dat de bomen hier niet zijn beïnvloed door eerdere grondwatermanipulaties in de jaren na 1980 en 1995 . De vergelijking is gemaakt door de middelcurves van eik, es en beuk, berekend uit de ruwe (niet gestandaardiseerde) boomcurves, in een grafiek te zetten (Figuur 6). De middelcurves van dezelfde soort groeiende in de twee bossen laten voor alle drie soorten sterke overeenkomsten in jaarlijkse en meer jaarlijkse variatie zien, voornamelijk in de laatste vijf decennia (vanaf 1970). Verschillen in meerjarige variatie in de periode voor 1970 zijn veroorzaakt door verschillen in leeftijdstrend van de gemiddelde bomen.

Gedurende de laatste decennia zijn tussen het Markiezenbos en het Trapeziumbos (als referentiebos) voor de drie boomsoorten geen verschillen in groei te zien, die zouden kunnen duiden op een negatieve invloed van veranderingen in grondwaterstand na 1980 of na 1995.
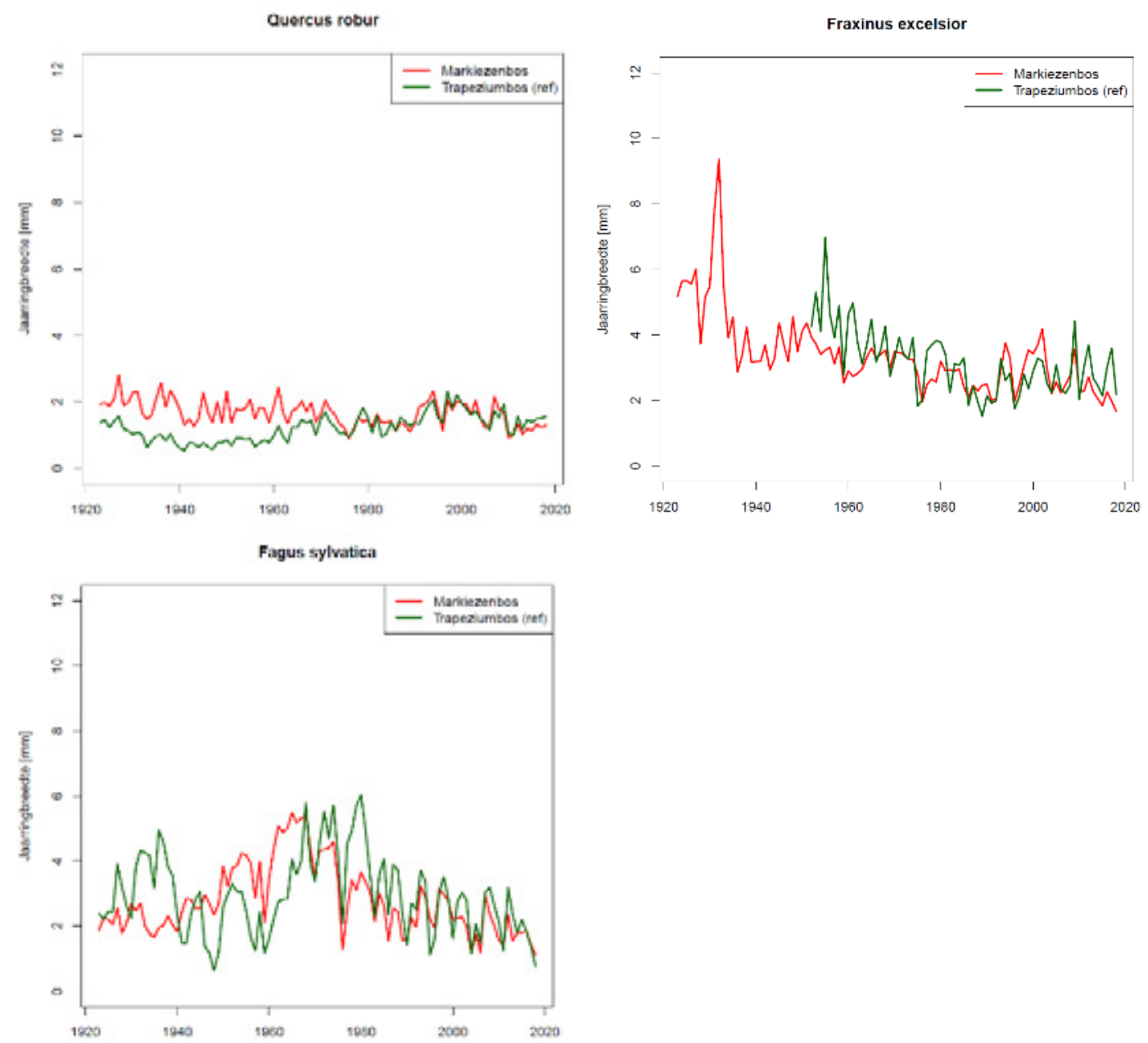

Figuur $7 \quad$ Vergelijking van middelcurves van eik (Quercus robur, links boven), es (Fraxinus excelsior, rechts boven), en beuk (Fagus sylvatica, onder) tussen Markiezenbos (rood) en Trapeziumbos (referentie, groen).

In Figuur 7 zijn de middelcurves van alle onderzochte bomen van de drie soorten met elkaar vergeleken (links: middelcurve gebaseerd op ruwe jaarringreeksen; rechts: middelcurve uit gestandaardiseerde jaarringreeksen). De middelcurves uit de ruwe jaarringreeksen laten wederom zien dat eik over de hele periode een lager groeiniveau heeft dan es en beuk. Alle soorten, maar in het bijzonder es, laten meerjarige variatie in het groeiniveau zien met fases van goede groei en mindere groei. Met name eiken en es vertonen overeenkomsten in lange- en kortetermijnvariatie. De 
rechtergrafiek met de middelcurve uit gestandaardiseerde boomcurves laat sterke overeenkomsten in jaarlijkse variatie tussen alle drie boomsoorten zien. Opvallend is de synchrone negatieve groeireactie in de middelcurves van de drie soorten in de jaren 1959, 1976 en 1996.
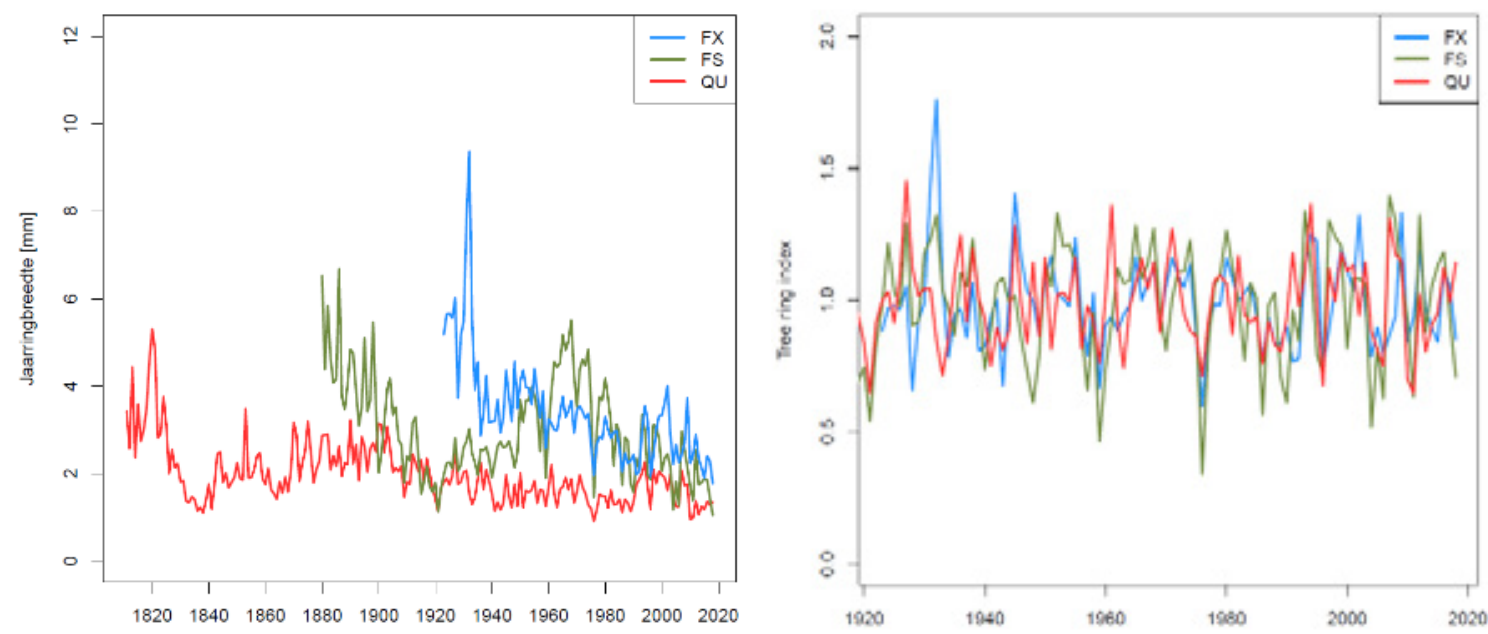

Figur 8 Vergelijking tussen middelcurves van eik (QU, rood), es (FX, blauw) en beuk (FS groen). Links: middelcurves uit ruwe jaarringreeksen, rechts middelcurves uit gestandaardiseerde jaarringreeksen.

\subsubsection{Reactie op klimaatfactoren}

\section{Droogtejaren}

Figuur 8 laat de indexmiddelcurves voor elke soort afzonderlijk zien, in directe vergelijking met de neerslagsom tijdens het groeiseizoen (van maart tot september) voor elk jaar. Hieruit blijkt dat de minima van 1959, 1976 en 1996 in jaarringbreedte samenvallen met jaren met extreem weinig neerslag tijdens het groeiseizoen. Het jaar 2003, gekenmerkt door droogte met name in de zomer, heeft bij alle drie soorten pas in 2004 tot een groeireductie geleid.

\section{Klimaat-groeirelaties voor beuk, es en eik}

Hier is gekeken naar de invloed van neerslag en temperatuur op de groei (= jaarringbreedte) van de drie boomsoorten. In Figuur 9 zijn de correlaties tussen de jaarringmiddelcurves van de drie soorten en de maandelijkse temperatuur en neerslag als staafjes afgebeeld. Daarbij is gekeken naar de correlatie met neerslag en temperatuur in juni van het vorige jaar (dus het effect van het vorige jaar op groei) tot september van het actuele jaar (normaal gesproken het einde van het groeiseizoen). De vette staafjes in de figuur wijzen op significante positieve (boven de nullijn) of negatieve correlaties. Dat wil zeggen dat de condities in deze significante maanden de groei van de betreffende boomsoort sterk bepalen.

Uit Figuur 9 blijkt globaal dat es en eik een vergelijkbare klimaat-groeirelatie vertonen. De groei van beide soorten wordt positief beïnvloed door meer neerslag in de winter en tijdens het begin van het groeiseizoen; er is geen duidelijke invloed van gemiddelde temperaturen. Beuk laat een andere klimaat-groeirelatie zien: de groei van beuk profiteert duidelijk van natte en koele condities gedurende de maanden mei, juni en juli. Dit duidt op gevoeligheid voor droogte gedurende deze periode. 


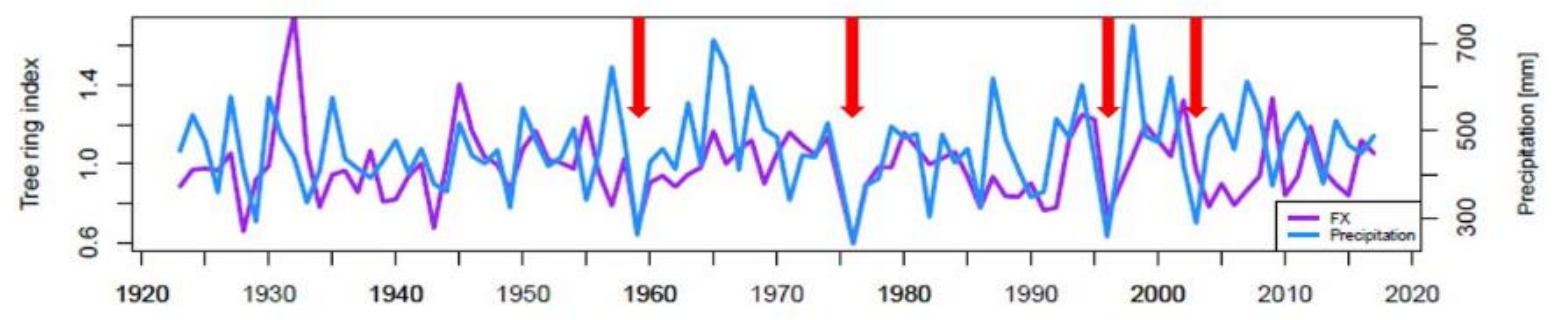

FS

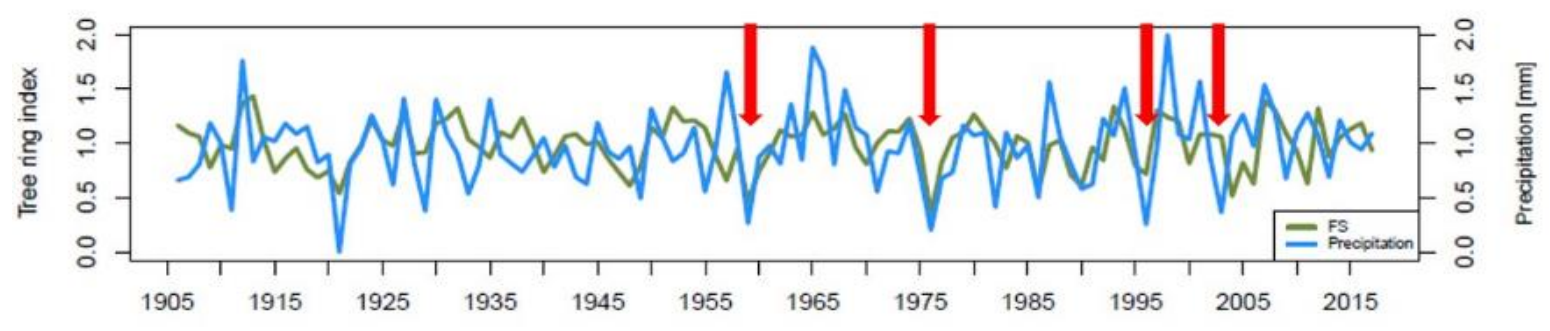

QU

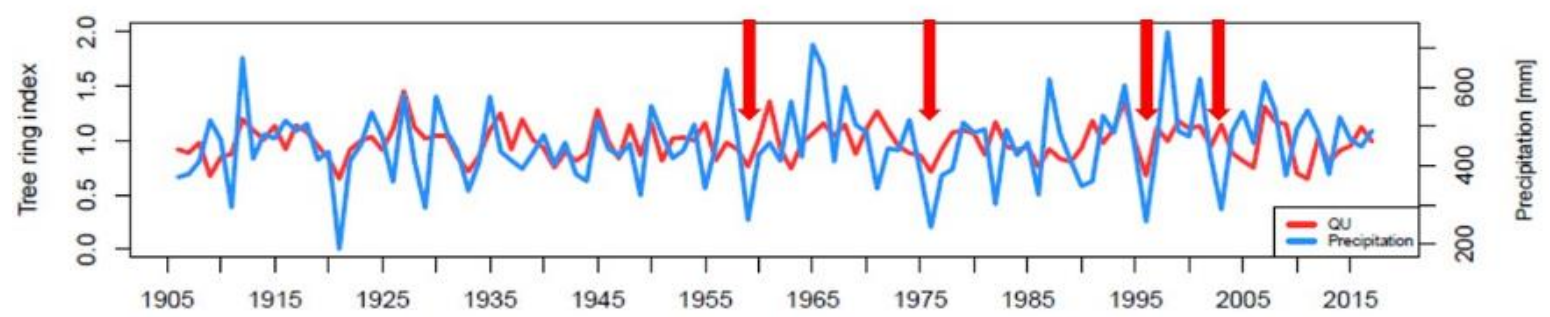

Figuur 9 Vergelijking tussen indexmiddelcurves van es (FX, boven), beuk (FS, midden) en eik (QU, onder) met neerslag tijdens het groeiseizoen (maart-sept., blauwe curve). Bekende droogtejaren 1959, 1976, 1996 en 2003 zijn met pijlen gemarkeerd.

\section{Resultaten per boomsoort:}

Beuk vormt een brede jaarring als er voldoende neerslag valt tijdens het groeiseizoen in mei, juni en juli. Tegelijk hebben hoge temperaturen in juli een negatieve invloed op de groei. Dit duidt op gevoeligheid voor zomerdroogte bij beuk: hoge temperaturen bij tegelijk weinig neerslag kunnen leiden tot waterdeficit en droogtestress en leiden tot vormen van een smalle jaarring.

Es reageert vooral positief op voldoende waterbeschikbaarheid in het begin van het groeiseizoen (mei). De positieve correlatie met neerslagcondities in de herfst van het vorige jaar en gedurende de winter hangt vermoedelijk samen met het opvullen van de waterreserves in de bodem.

Eik profiteert zoals es van veel neerslag in de wintermaanden november en december, maar groeit ook beter als het in juni veel regent. Juni is de periode van maximale groei van eik.

De klimaat-groeirelaties van alle drie boomsoorten laten zien dat er een invloed is van de klimaatomstandigheden op de groei. De correlaties met neerslag en in het bijzonder temperatuur zijn echter relatief laag. Dit is karakteristiek voor bomen die onder standplaatsomstandigheden met goede nutriënten- en vochtvoorzieningen groeien. Alleen bij beuk is er een gevoeligheid voor droogte gedurende de zomer aanwezig. Uit Figuur 8 blijkt echter dat de drie soorten in (extreme) jaren met weinig neerslag tijdens het groeiseizoen duidelijke groeidepressies vormen. Dat geldt voor es en beuk vermoedelijk ook voor het jaar 2018 (ook was de ring nog niet volledig tijdens de monstername op 8 augustus). 
Uit de klimaat-groeianalyse kan worden geconcludeerd dat de groei van eik, es en beuk op Amelisweerd in het algemeen positief wordt beïnvloed door veel neerslag. Eik en es profiteren met name van veel neerslag in de herfst en winter voor het groeiseizoen en natte condities in het begin van het groeiseizoen, in mei en juni. De groei van beuk is sterker afhankelijk van goede weersomstandigheden tijdens het groeiseizoen dan de beide andere soorten. De groei van beuk profiteert van natte en koele omstandigheden van mei tot juli. Droge condities in deze periode leiden tot smalle jaarringen bij beuken.

Alle soorten reageren echter met groeidepressies op droogtejaren, zoals in 1959, 1976 en 1996. Deze jaren zijn gekenmerkt door weinig neerslag in combinatie met hoge temperaturen tijdens het groeiseizoen of in de zomer (2003).

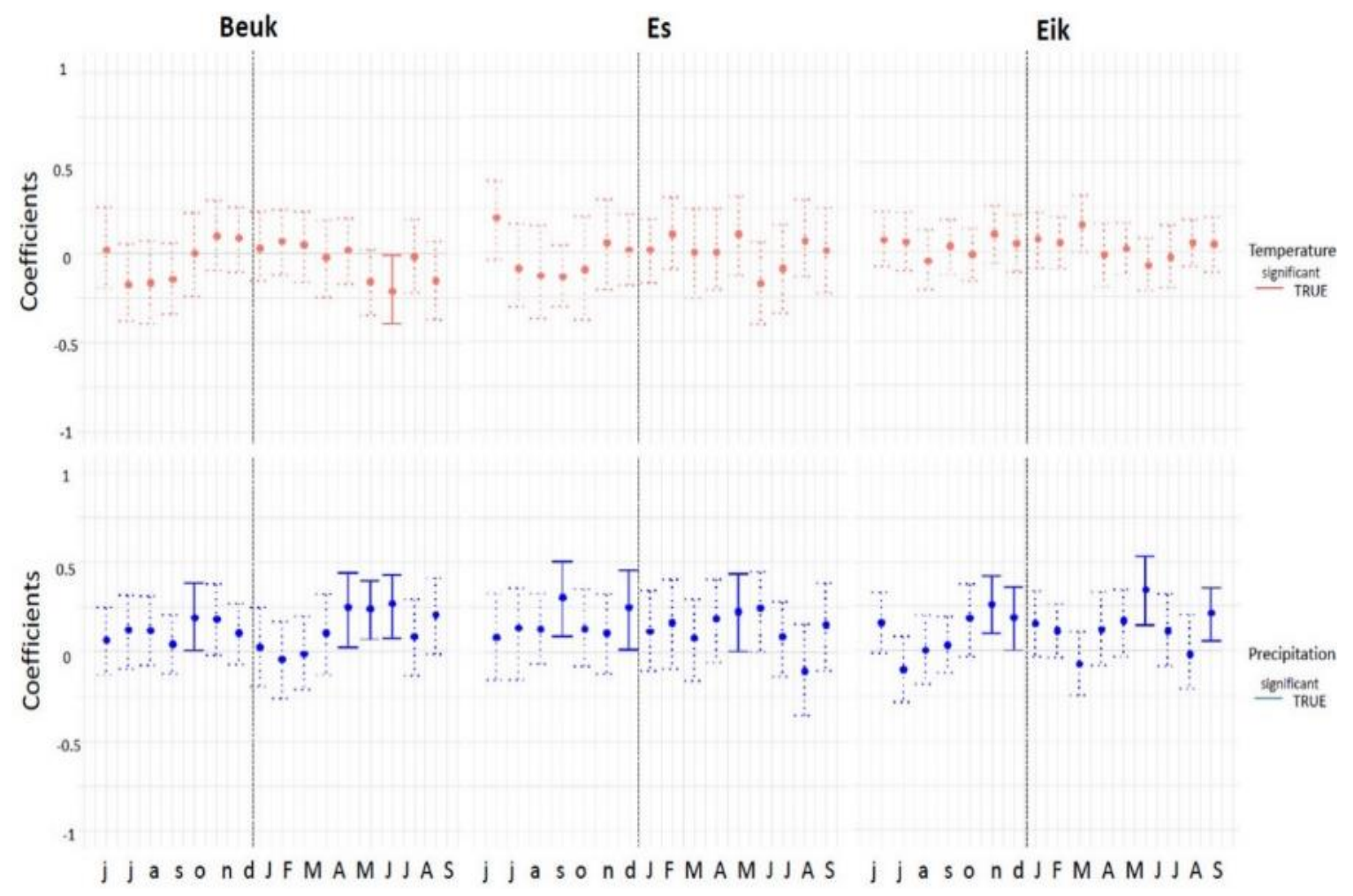

Figuur 10 Klimaat-groeirelaties van beuk (links), es (midden) en eik (rechts).

Boven (rood) correlatie met gemiddelde temperatuur van juni vorig jaar tot september (actueel jaar); beneden (blauw) correlatie met neerslagsom van juni vorig jaar tot september (actueel jaar); significante correlaties als vette staafjes.

\subsubsection{Samenvattende analyse jaarringgegevens}

Analyse van de korte- en langetermijngroeidynamiek van eiken, essen en beuken in het Markiezenbos en Trapeziumbos in Amelisweerd laat geen verband zien met de verlaging van grondwaterstanden in de jaren 80 of de verhoging van het peil in de Kromme Rijn eind jaren 90. De jaarringpatronen van alle onderzochte bomen wijzen niet op een verlaagde vitaliteitsstatus in de laatste decennia of jaren. De groeipatronen van de onderzochte bomen variëren sterk, wat veroorzaakt is door verschillen in leeftijd, maar ook in micro-standplaatsomstandigheden, zoals ook blijkt uit de profielbeschrijvingen die aantonen dat zowel de bodemstructuur als de diepte van het grondwater op korte afstand sterk varieert.

De groei van de drie onderzochte boomsoorten is beïnvloed door jaarlijks wisselende weersomstandigheden. De drie soorten variëren in klimaat-groeirelaties, maar laten alle een sterk effect van droogtejaren (jaren met weinig neerslag tijdens het groeiseizoen) op de groei zien.

De onderzochte bomen hebben in het verleden geen negatieve groeireactie laten zien op bekende grondwaterdaling bij de aanleg van de A27 begin jaren 80 en de peilverhoging van de Kromme Rijn 
eind jaren 90. Dit duidt op plasticiteit van de onderzochte bomen in reactie op veranderende groeiomstandigheden.

Op basis van deze resultaten kan de volgende inschatting worden gemaakt over een mogelijke (groei)reactie van de drie boomsoorten op toekomstige (kunstmatige) veranderingen in het grondwaterniveau. De bomen reageren plastisch op verlaging in het grondwaterniveau, verondersteld dat het niveau van verlaging in de orde van grootte ligt zoals in het verleden. Het onderzoek heeft echter ook laten zien dat alle drie soorten gevoelig zijn voor jaren met zeer droge condities tijdens het groeiseizoen. Op basis van dit onderzoek kan geen uitspraak worden gedaan over wat de consequentie is van een gecombineerd effect van grondwaterverlaging met één of zelfs meerdere droge jaren. De grondwaterdalingen in het verleden gingen niet gepaard met droogtejaren.

Op basis van deze conclusie wordt aanbevolen om het effect van de geplande grondwaterverlaging nauwkeurig te monitoren. Daarbij zou naast monitoren middels peilbuizen en vochtsensoren ook het effect op de bomen direct (in realtime met dendrometers en sapflowmeters) gemeten kunnen worden. 


\section{$4 \quad$ Synthese en eindconclusies}

Nadat in het vorige hoofdstuk de drie afzonderlijke onderdelen (bodem, vitaliteit en groei) zijn behandeld, wordt in dit hoofdstuk de relatie gelegd tussen de resultaten van de afzonderlijke onderdelen. Ten eerste wordt er gekeken naar de effecten van grondwaterverlaging en ten tweede komt de autonome ontwikkeling aan bod. Tabel 1 is een overzicht van een aantal van de meetgegevens van de deelonderzoeken bodem, vitaliteit en groei. De omschrijvingen van de rol van de boom in het kronendak en de conditie zijn samen met eventuele aantastingen uitgebreider beschreven in bijlage 2 . 


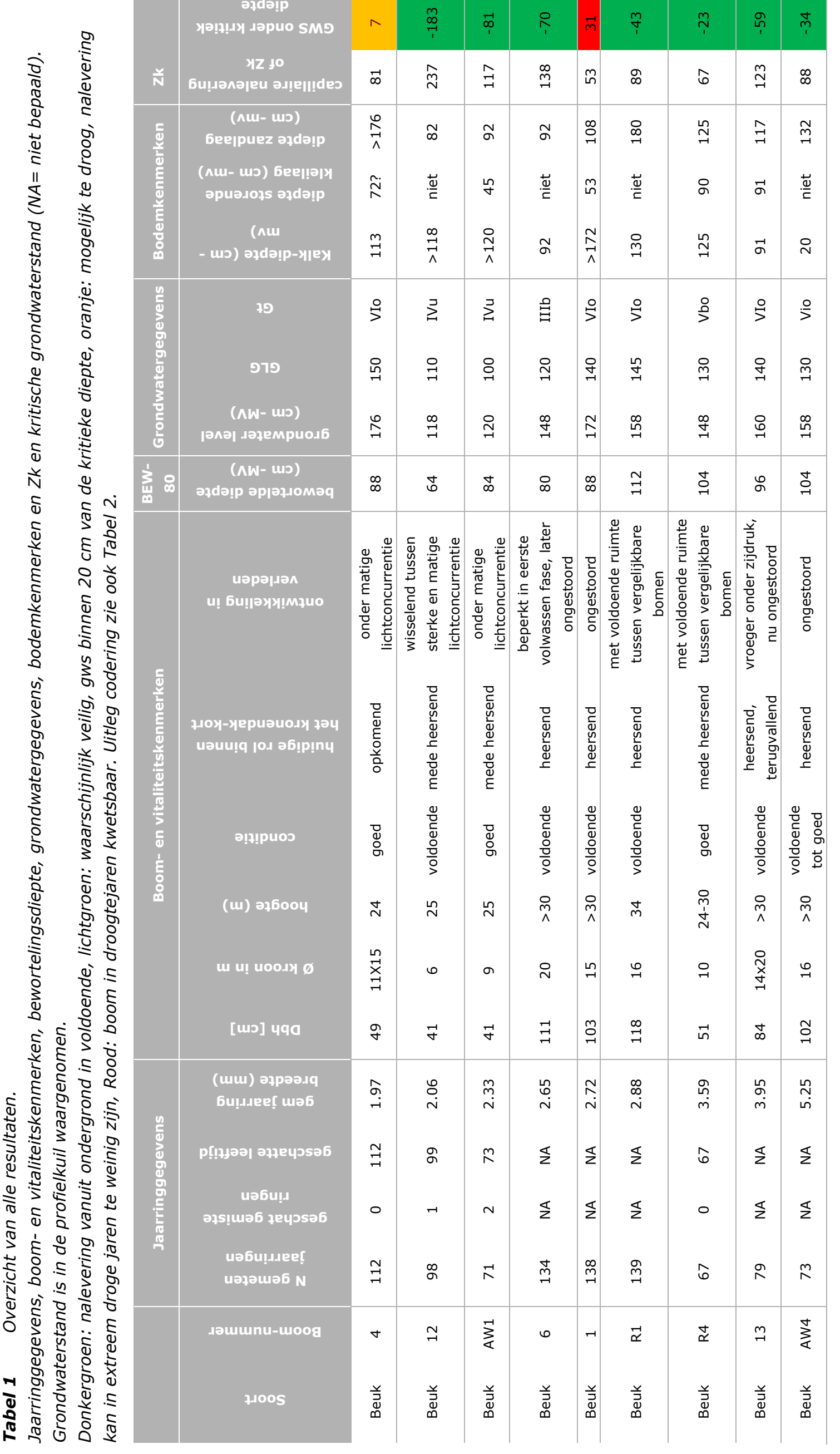




\begin{tabular}{|c|c|c|c|c|c|c|c|c|c|c|c|c|}
\hline & 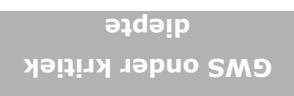 & $\Rightarrow$ & 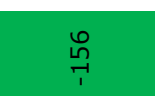 & ధి & $\infty$ & 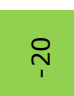 & $\stackrel{\mathscr{L}}{\sim}$ & $\vec{m}$ & yे & m & ન & $\overrightarrow{7}$ \\
\hline 前 & 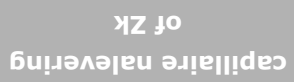 & in & $\stackrel{n}{N}$ & $\underset{\rightarrow}{\stackrel{m}{-}}$ & $\infty$ & $\stackrel{\infty}{\rightarrow}$ & 藏 & $\stackrel{\infty}{\sigma}$ & $\hat{\jmath}$ & g & $\tilde{\omega}$ & $\hat{o}$ \\
\hline 遶 & 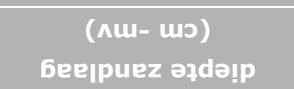 & ร & 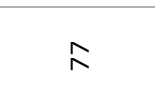 & $\infty$ & ஃ & $N$ & $\stackrel{n}{\rightarrow}$ & $\underset{\hat{\omega}}{\hat{\Lambda}}$ & $\stackrel{0}{-1}$ & 兄 & $\stackrel{\infty}{+}$ & $\tilde{\infty}$ \\
\hline$\stackrel{d}{E}$ & 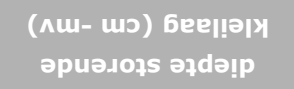 & $\stackrel{\square}{\frac{\breve{v}}{E}}$ & 吕 & $\stackrel{\stackrel{\mathscr{U}}{E}}{=}$ & $\vec{m}$ & $\stackrel{\vec{\omega}}{\frac{\omega}{\tau}}$ & $\stackrel{\overrightarrow{\mathscr{U}}}{=}$ & $\stackrel{\infty}{+}$ & $\frac{\vec{\omega}}{\bar{c}}$ & $\stackrel{\vec{\omega}}{\tilde{\tau}}$ & $\stackrel{\text { n }}{\rightarrow}$ & $\stackrel{\stackrel{\vec{U}}{\pi}}{\pi}$ \\
\hline \% & 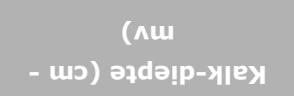 & $\hat{o}$ & 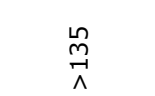 & $\underset{\wedge}{\stackrel{ }{\wedge}}$ & $\stackrel{\vec{m}}{\vec{r}}$ & $N$ & $\stackrel{\stackrel{m}{m}}{\rightarrow}$ & $\begin{array}{l}\hat{0} \\
\stackrel{1}{\Lambda}\end{array}$ & 织 & $\underset{\sim}{\stackrel{n}{n}}$ & $\stackrel{\text { n }}{\rightarrow}$ & $\tilde{\infty}$ \\
\hline$\stackrel{0}{0}$ & เอ & $\stackrel{\circ}{>}$ & $\sum^{2}$ & 寻 & $\stackrel{9}{\lessgtr}$ & 急 & 自 & 党 & $\stackrel{\circ}{9}$ & $\stackrel{\circ}{\lessgtr}$ & $\stackrel{\circ}{>}$ & $\sum_{2}^{2}$ \\
\hline$\frac{1}{5}$ & כרכ & $\stackrel{\sim}{\sim}$ & 임 & 8 & $\stackrel{\circ}{\circ}$ & $\stackrel{\circ}{n}$ & 옥 & $\stackrel{\text { Tิ }}{T}$ & $\underset{-1}{\stackrel{0}{0}}$ & $\stackrel{\infty}{\rightarrow}$ & $\underset{T}{g}$ & $\stackrel{ }{\rightarrow}$ \\
\hline 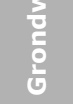 & $\begin{array}{c}\text { (АW- นว) } \\
\text { Гәәә дәңемриодб }\end{array}$ & $\underset{\vec{G}}{\vec{J}}$ & $\underset{\sim}{m}$ & $\underset{7}{\stackrel{-}{-}}$ & $\stackrel{0}{2}$ & $\stackrel{\infty}{\stackrel{\infty}{\sim}}$ & $\underset{\sim}{\stackrel{T}{T}}$ & 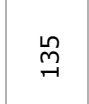 & $\underset{7}{0}$ & $\underset{f}{f}$ & $\stackrel{0}{\stackrel{1}{7}}$ & 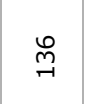 \\
\hline 寍市 & 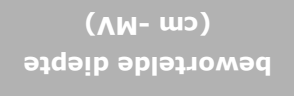 & $\triangleright$ & मे & 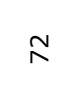 & O্- & $\infty$ & $\dot{z}$ & $\stackrel{\infty}{0}$ & 8 & 苛 & ஃ & ০ \\
\hline & 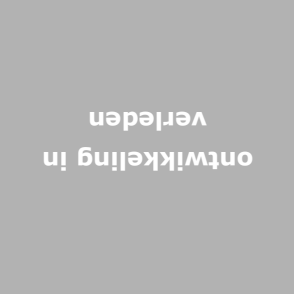 & 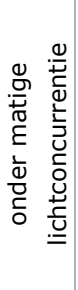 & 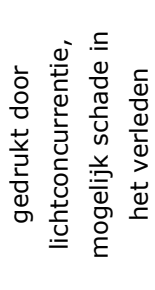 & 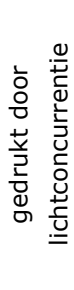 & 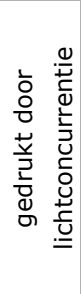 & 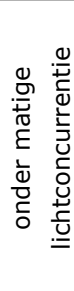 & 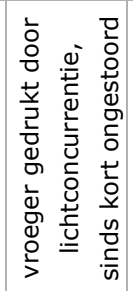 & 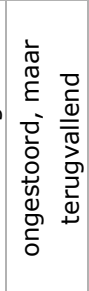 & 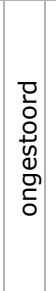 & 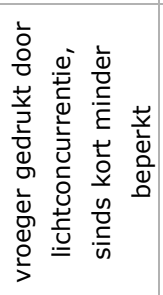 & 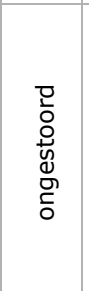 & 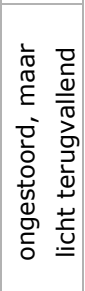 \\
\hline 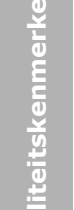 & 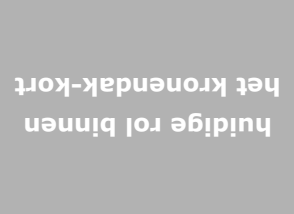 & 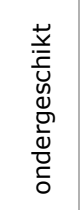 & 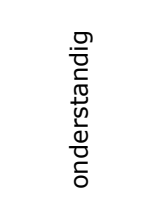 & 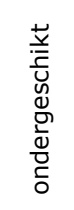 & 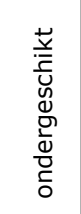 & 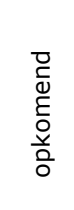 & 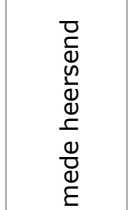 & 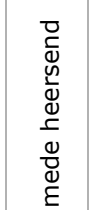 & 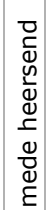 & 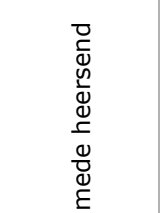 & 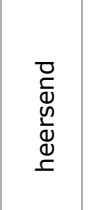 & 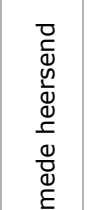 \\
\hline $\begin{array}{l}\bar{g} \\
\frac{5}{5} \\
\overline{0} \\
\dot{y} \\
\dot{y}\end{array}$ & әџңриог & $\begin{array}{l}\frac{0}{0} \\
\frac{0}{0} \\
\frac{0}{0} \\
\frac{0}{7}\end{array}$ & 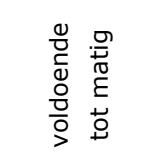 & $\begin{array}{l}\frac{0}{0} \\
\frac{0}{0} \\
\frac{0}{0} \\
\frac{0}{\partial}\end{array}$ & $\begin{array}{l}\frac{0}{0} \\
\overline{0} \\
\frac{0}{0} \\
\frac{0}{0} \\
>\end{array}$ & $\begin{array}{l}\frac{0}{0} \\
\frac{0}{0} \\
\frac{0}{0} \\
\frac{0}{0} \\
>\end{array}$ & $\begin{array}{l}\frac{0}{0} \\
\frac{\bar{\Xi}}{\mathbb{0}} \\
\frac{0}{0} \\
\frac{0}{9}\end{array}$ & 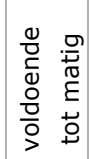 & 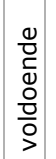 & $\begin{array}{l}\frac{0}{0} \\
\frac{0}{0} \\
\frac{0}{0} \\
\frac{0}{0}\end{array}$ & 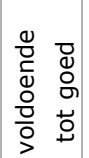 & 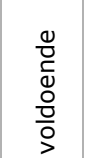 \\
\hline ๓े & (u) әұбооч & $\stackrel{m}{\wedge}$ & i & $\stackrel{\circ}{\wedge}$ & $\stackrel{m}{n}$ & $\underset{\wedge}{\stackrel{E}{N}}$ & p & m & $\underset{\substack{E \\
N}}{\Lambda}$ & $\stackrel{\infty}{\wedge}$ & $\stackrel{\infty}{\wedge}$ & $\stackrel{\circ}{\wedge}$ \\
\hline & ૫ ч! นоодя ø & in & $\infty$ & $\bullet$ & 울 & $a$ & $\infty$ & $a$ & $\vec{A}$ & $\stackrel{0}{-1}$ & $\underset{T}{ \pm}$ & 艾 \\
\hline & [uว] чqव & ช & $\vec{m}$ & $\hat{N}$ & $\stackrel{\forall}{\forall}$ & $\stackrel{m}{m}$ & $\stackrel{m}{q}$ & 串 & เ̂́ & i̊ & मे & $\stackrel{n}{2}$ \\
\hline & $\begin{array}{l}\text { (uш) әұрәәдq } \\
\text { би!лдеe! шәб }\end{array}$ & $\Sigma$ & 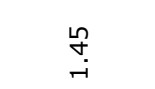 & $\stackrel{n}{\stackrel{n}{r}}$ & $\stackrel{+}{i}$ & $\stackrel{\stackrel{8}{0}}{i}$ & $\underset{\substack{+ \\
\text { i }}}{ }$ & $\underset{\sim}{N}$ & $\stackrel{m}{m} \underset{m}{m}$ & 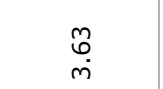 & $\underset{\substack{น ٌ \\
\sim}}{\sim}$ & $\begin{array}{l}\infty \\
\stackrel{\infty}{\circ} \\
\dot{\sigma}\end{array}$ \\
\hline 总 & 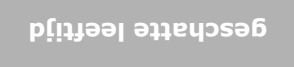 & $\frac{\pi}{z}$ & $\stackrel{\circ}{\circ}$ & $\stackrel{n}{\circ}$ & $\frac{\pi}{z}$ & J̊ & $\stackrel{\infty}{\infty}$ & $\stackrel{m}{\infty}$ & a & $\stackrel{\infty}{\infty}$ & $\frac{\pi}{z}$ & $\frac{\pi}{z}$ \\
\hline 는 & 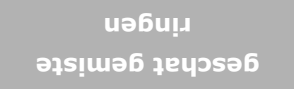 & $\frac{\pi}{z}$ & 호 & $\circ$ & $\frac{\pi}{z}$ & $\bullet$ & m & $\circ$ & $\wedge$ & -1 & $\frac{\pi}{z}$ & $\frac{\pi}{z}$ \\
\hline & $\begin{array}{l}\text { иәби!...еe! } \\
\text { иәңәшәб } \mathbf{N}\end{array}$ & $\Sigma$ & $\stackrel{m}{\infty}$ & $\overrightarrow{0}$ & $\stackrel{\circ}{\circ}$ & $\stackrel{\infty}{n}$ & 绐 & $\infty$ & $N$ & $\hat{6}$ & $\infty$ & กొ \\
\hline & 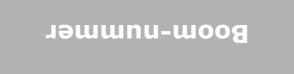 & $a$ & $\Rightarrow$ & $\infty$ & $\stackrel{\infty}{\rightarrow}$ & $\sum_{\varangle}^{n}$ & $\stackrel{\varphi}{\check{q}}$ & 욱 & $\sum_{\overleftarrow{4}}^{n}$ & $\tilde{\alpha}$ & $\stackrel{0}{\rightarrow}$ & in \\
\hline & 7.005 & 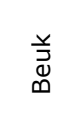 & $\begin{array}{l}0 \\
0 \\
\dot{0} \\
0\end{array}$ & $\begin{array}{l}\mathscr{0} \\
\dot{3} \\
0 \\
0\end{array}$ & 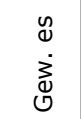 & $\begin{array}{l}\mathscr{0} \\
\dot{y} \\
心\end{array}$ & 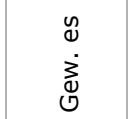 & 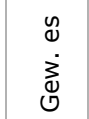 & $\mid \begin{array}{l}0 \\
0 \\
\dot{z} \\
0\end{array}$ & $\begin{array}{l}0 \\
0 \\
\dot{3} \\
0\end{array}$ & $\begin{array}{l}0 \\
0 \\
3 \\
0 \\
0\end{array}$ & $\begin{array}{l}0 \\
0 \\
⿱ 亠 䒑 \\
0\end{array}$ \\
\hline
\end{tabular}




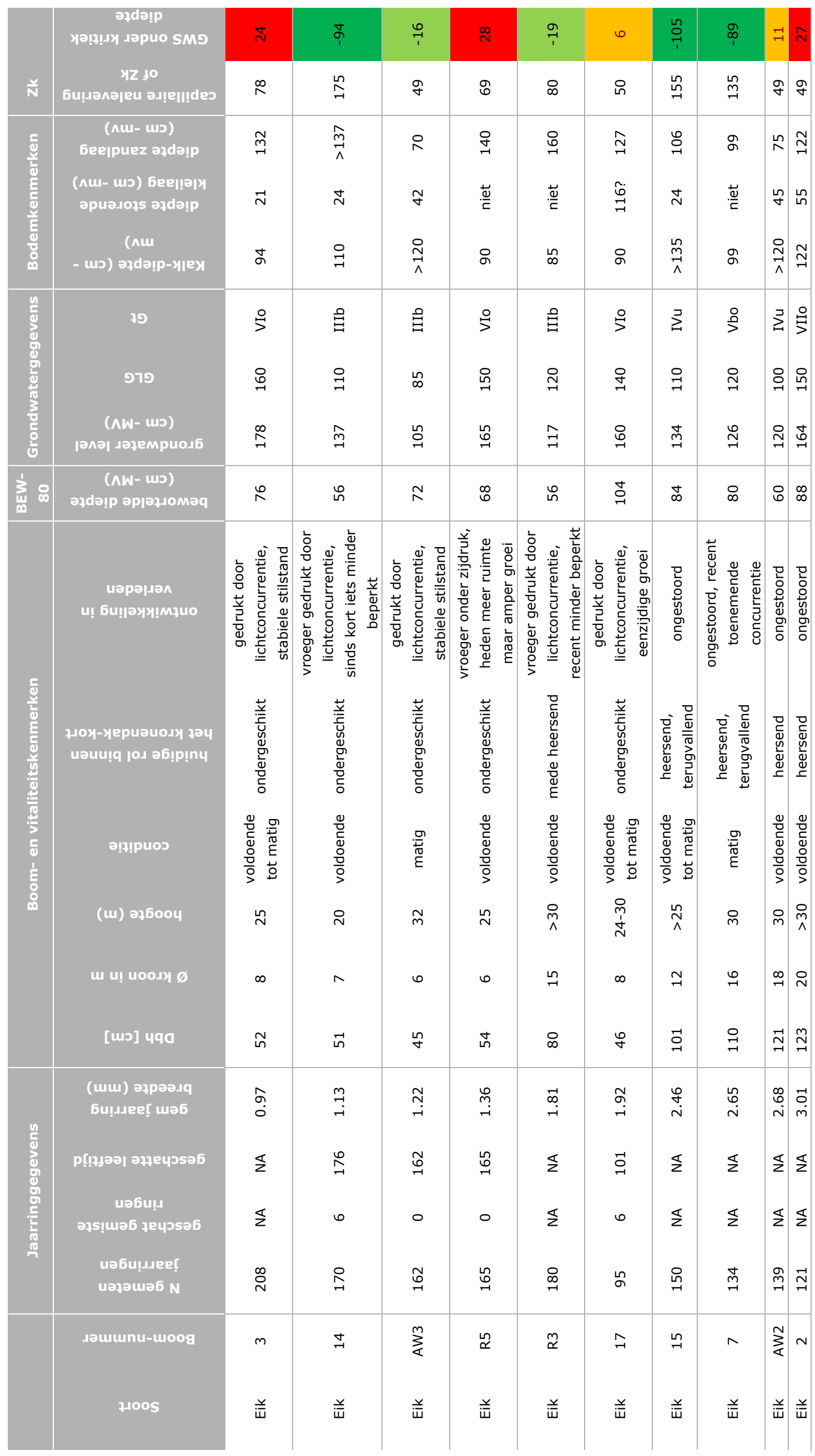




\subsection{Effecten van grondwater op boomgroei en vitaliteit in het Markiezenbos}

\subsubsection{Gebufferd grondwatersysteem}

Uit de jaarringanalyses blijkt dat de onderzochte bomen in het verleden geen negatieve groeireactie op bekende grondwaterdalingen hebben laten zien tijdens de aanleg van de A27 begin jaren 80 en de aanpassing van de grondwaterstanden eind jaren 90 . Ook uit de analyses van de peilbuisdata is geconcludeerd dat er in Amelisweerd sprake is van een gebufferd grondwatersysteem, dat wordt gevoed door infiltratie vanuit de Kromme Rijn. De evapotranspiratie die overdag plaatsvindt, wordt 's nachts aangevuld, zodat het grondwater net weer een paar centimeters stijgt, ook wanneer er geen regenwater is gevallen (Figuur 11). Het grondwatersysteem in het Markiezenbos wordt ook gebufferd door toestroom van grondwater dat geïnfiltreerd is op de Utrechtse Heuvelrug. Alhoewel Amelisweerd niet gekarakteriseerd kan worden als een kwelgebied, kan de voeding met regionaal grondwater er wel voor zorgen dat de grondwaterstand niet te ver wegzakt (Van der Grift et al., in voorbereiding). Deze buffering door oeverinfiltratie vanuit de Kromme Rijn en de regionale kwel, levert een positieve bijdrage aan de overleving van het bos tijdens een drogere periode. Voor de jaarringanalyses moet wel worden opgemerkt dat de bemonstering alleen heeft kunnen plaatsvinden bij bomen die de gebeurtenissen in het verleden hebben overleefd. Of er daadwerkelijk bomen zijn afgestorven na de aanleg van de $A 27$ is niet bekend.

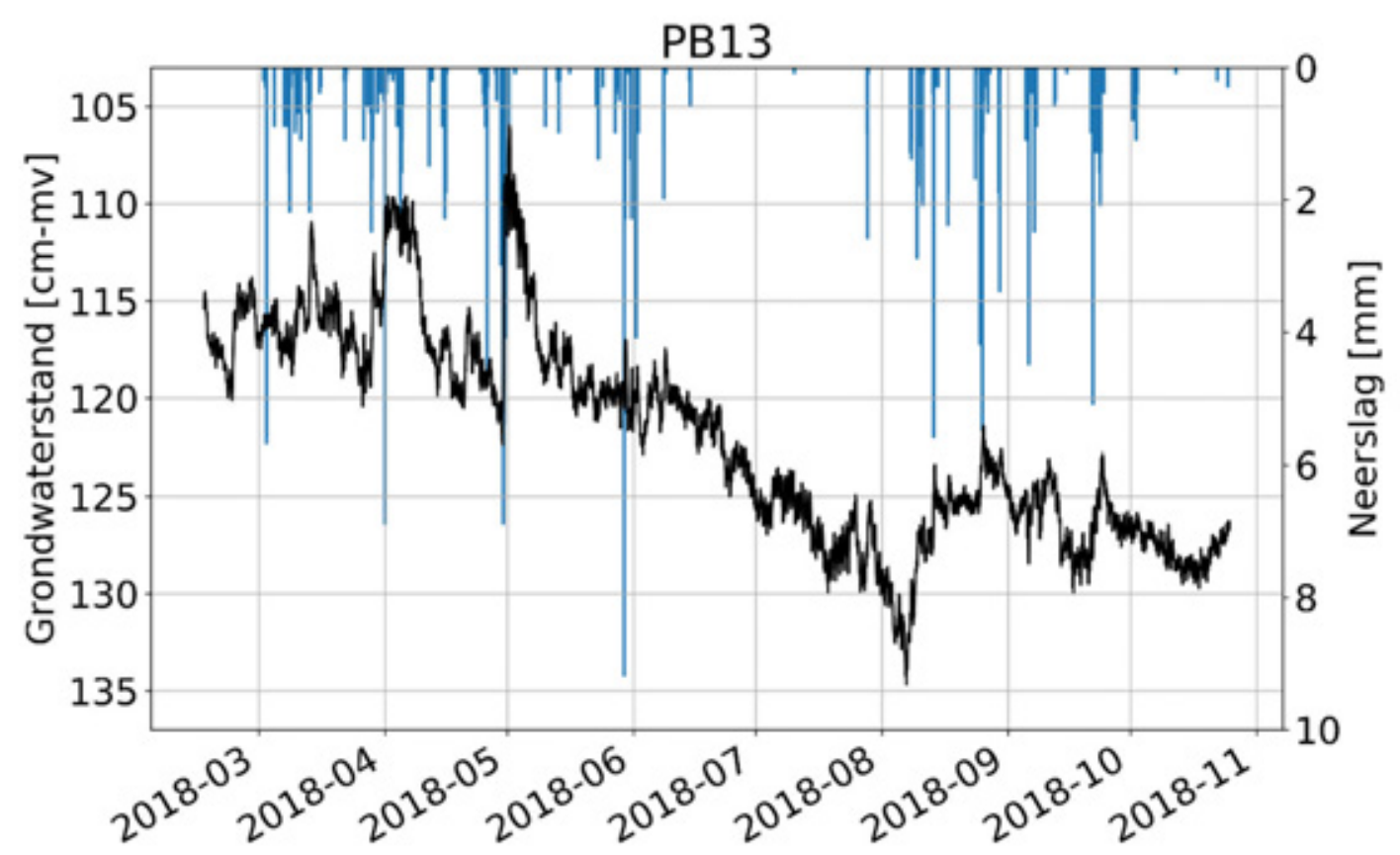

Figuur 11 Verloop grondwaterstand en neerslag in het extreem droge jaar 2018 (PB13). In augustus werd het laagste grondwaterpeil gemeten, circa $30 \mathrm{~cm}$ lager dan het hoogst gemeten waterpeil in mei.

Extreme droogte zoals in 1959 en 1976 veroorzaakt groeidepressies in de onderzochte bomen. Ten tijde van de wegaanleg zijn geen extreme droogtejaren opgetreden. De invloed van extra grondwateronttrekking bij werkzaamheden aan de weg in combinatie met een droogtejaar zoals 1976 of 2018, kan er wel toe leiden dat het contact tussen de boomwortels en het grondwater langdurig verbroken is en niet meer overbrugd kan worden door de capillaire nalevering. Wanneer deze situatie te lang voortduurt, zullen er zeker bomen (kunnen) doodgaan. Tijdens het extreem droge jaar 2018 daalde de grondwaterstand en werd begin augustus het laagste grondwaterpeil gemeten, circa $30 \mathrm{~cm}$ lager dan het hoogst gemeten waterpeil in mei 2018. 


\subsubsection{Capillaire nalevering}

De capillaire nalevering uit de ondergrond is belangrijk voor boomgroei en vitaliteit ten tijde van droogte. Als het grondwater zover daalt en de capillaire nalevering te gering is, kan er verdroging optreden. Dit kan leiden tot bladval en groeistagnatie en bij langdurige droogte zelfs tot sterfte van bomen. Met behulp van de kritieke z-afstand Zk kan onderzocht worden waar en wanneer er verdrogingsproblemen kunnen ontstaan. $Z \mathrm{k}$ is de afstand tussen het grondwater en de onderkant van de effectieve wortelzone, waarover een flux van $2 \mathrm{~mm} / \mathrm{dag}$ nog net mogelijk is en de boom voldoende vocht uit de ondergrond heeft. Deze waarde is berekend op basis van de bodemkenmerken textuur, gelaagdheid, rijping en grondwaterstanden.

Op basis van deze waarde is de minimale grondwaterstand berekend die bereikt kan worden zonder dat er verdrogingsgevaar voor de boom optreedt. Dit is gedaan door de Zk op te tellen bij de effectieve bewortelingsdiepte (BEW-80). De kritische grondwaterstand die hieruit volgt, is in de laatste kolom van Tabel 1 opgenomen. Komt het grondwater onder deze diepte uit, dan is het contact van de wortels met de ondergrond verbroken. Wanneer deze situatie langer blijft bestaan, treedt verdroging op. In Tabel 1 is met kleuren aangegeven wanneer de Zk te klein is om voldoende nalevering te geven: rood gemarkeerd zijn de bomen die bij langdurige droogte het gevaar op verdroging kunnen lopen, groen gemarkeerd zijn de bomen die ook tijdens droogte voldoende nalevering krijgen vanuit de ondergrond. Het grondwater zal voor de groen gemarkeerde bomen altijd in de buurt van de boomwortels blijven of het vocht zal door nalevering voldoende beschikbaar blijven. Met behulp van het aangelegde peilbuizennetwerk in de omgeving van de bomen worden de grondwaterstanden gemonitord.

De beoordeling van de mogelijke effecten van een onderbemaling op de vitaliteit van de bomen is gebaseerd op veldwaarnemingen, metingen en een aantal berekeningen. Voor bomen die mogelijk in de problemen komen, zal door monitoring van de grondwaterstand bepaald moeten worden of extra verdroging te verwachten is. Dat is dus het geval wanneer de grondwaterstand daalt onder de kritieke diepte. De kritieke z-afstand is afgeleid op basis van textuurschattingen en gemiddelde bodemfysische eigenschappen van vergelijkbare gronden in Nederland. De actuele grondwaterstanden voor de droge zomer van 2018 zijn gemeten in de profielkuilen. Hiermee kan bepaald worden welke bomen in de huidige situatie met een vochttekort bedreigd worden en welke niet (zie Tabel 1 en Figuur 12 en Figuur 13). Hieruit volgt ook welke bomen gemonitord zouden moeten worden.

In Figuur 12 en Figuur 13 zijn twee dwarsdoorsnedes door het Markiezenbos weergegeven waarin de gemeten variabelen van de dikte van de kleilaag, de hoogste (HG) en de laagste grondwaterstand (LG) gemeten in de peilbuizen in de zomer van 2018, de gemeten bewortelingsdiepte (BEW) en de kritische grondwaterstand voor verdroging (BEW+Zk: rode lijn) zijn weergegeven. De aangegeven greppel in de figuur loopt links van de toevoerweg vanuit de Koningsweg richting het noorden. Ter hoogte van deze weg met greppel bevindt zich waarschijnlijk de kwetsbaarste zone voor verdroging. Dit is in de figuren af te lezen waar de rode lijn voor kritische grondwaterstand de LG raakt of zelfs er boven komt.

In de dwarsdoorsnede parallel aan de Koningsweg (Figuur 13) is de zone met kans op verdroging breder dan ter hoogte van de noordelijke dwarsdoorsnede. Een aantal van de rood gemerkte bomen in Tabel 1 staat ter hoogte van deze greppel en aan de zuidkant van het Madammenlaantje (Beuk 1 en eik 2 en iets noordelijker eik 3 ).

De kritische grondwaterstanden zijn niet eenduidig te correleren met groei en vitaliteitskenmerken. Bomen met een goede conditie kunnen een mindere gemiddelde groei hebben dan bomen met een iets mindere conditie. Voorbeelden hierbij zijn beuk 4 met een ogenschijnlijk goede conditie, die de laagste gemiddelde jaarringbreedte heeft in vergelijking met beuk 13, die een voldoende conditie heeft bij een gemiddelde jaarringbreedte die bijna 2 keer zo groot is. Bij eiken is eenzelfde vergelijking te maken tussen bijvoorbeeld eik 14 en eik 15. Beide bomen zijn ongeveer even oud, maar boom 15 heeft gedurende zijn hele leven een snellere groei gekend, zich uitend in een gemiddelde jaarringbreedte die ruim 2 keer zo groot is als van eik 14 (Tabel 1). Op basis van zijn uiterlijk lijkt boom 14 echter vitaler, terwijl eik 15 een beginnende aftakeling laat zien doordat zware takken uit de kroon zijn uitgebroken. De groei van eik 15 is tot in 2018 beter dan die van eik 14 (zie bijlage 3).

Hieruit kan worden geconcludeerd dat op basis van de uiterlijke kenmerken van de bomen in het Markiezenbos niet kan worden vastgesteld of de groei slecht is. Zolang er jaarlijks voldoende bijgroei is, is de vitaliteit van de boom goed. 


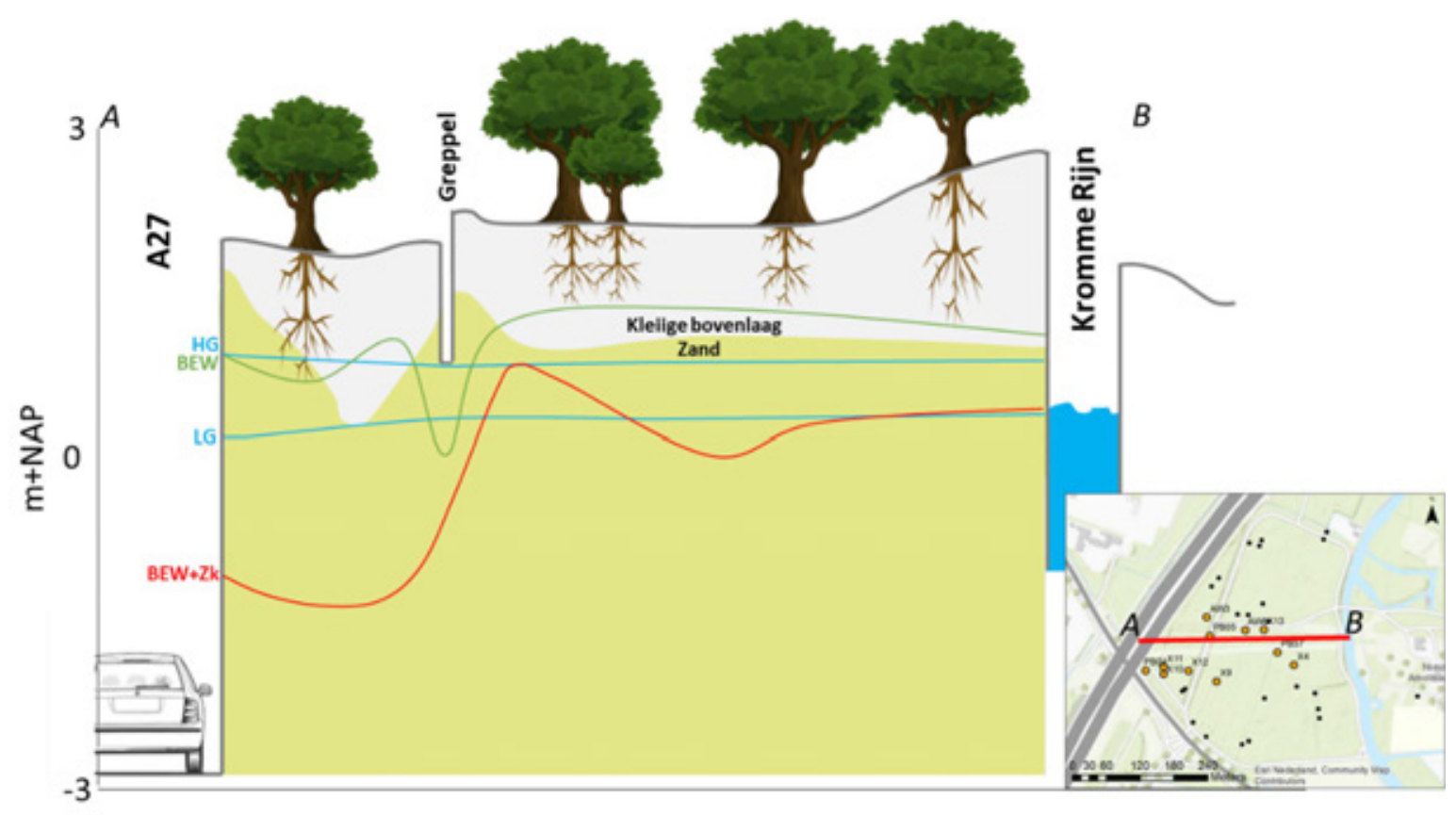

Figuur 12 Dwarsdoorsnede voor het Markiezenbos ten noorden van het Sneeuwklokjeslaantje. De hoogste (HG) en de laagste grondwaterstand (LG) gemeten in de peilbuizen, de gemeten bewortelingsdiepte (BEW) en de kritische grondwaterstand voor verdroging (BEW+Zk: rode lijn) zijn weergegeven.

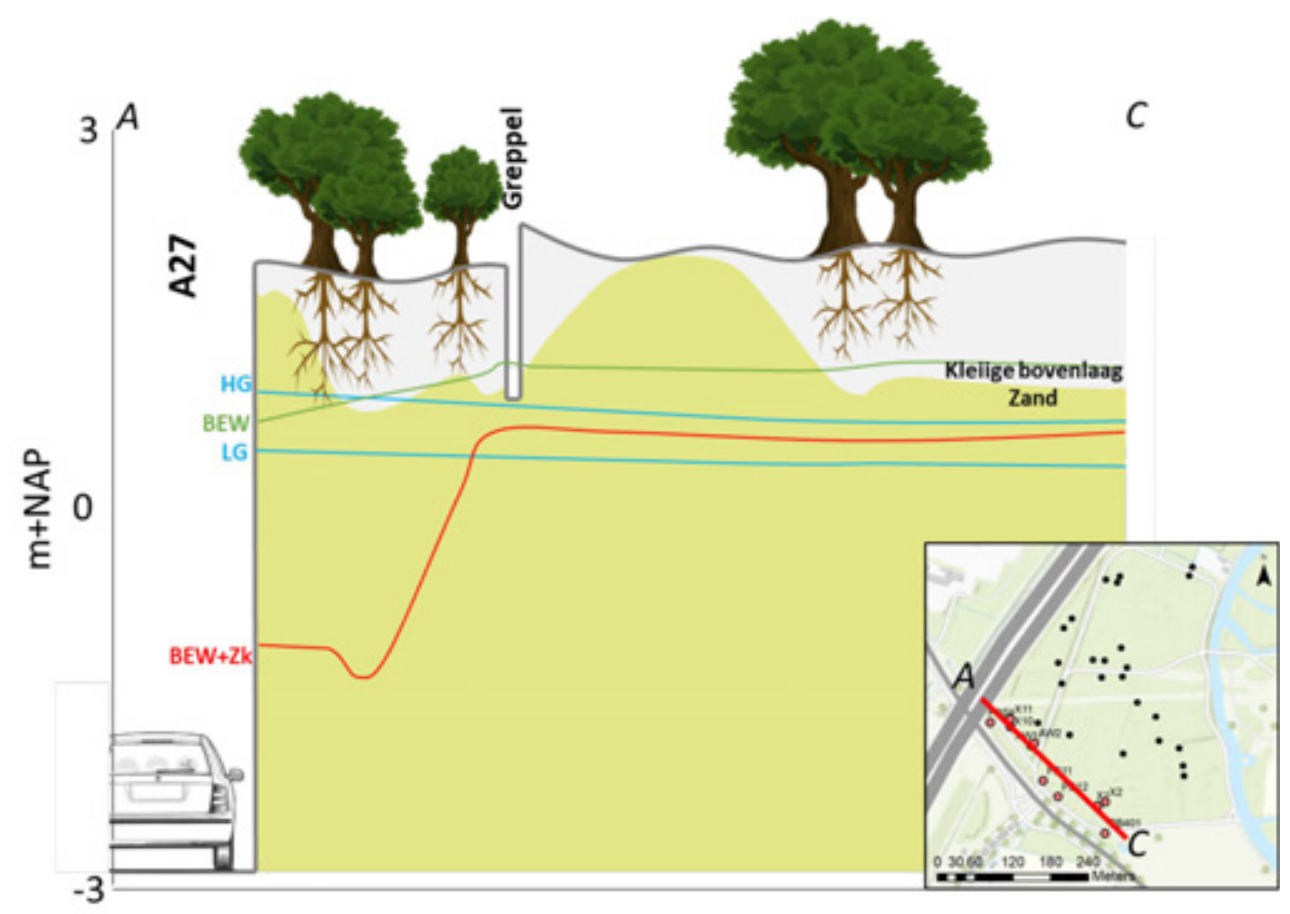

Figuur 13 Dwarsdoorsnede voor de zuidwestkant van het Markiezenbos. De hoogste (HG) en de laagste grondwaterstand (LG) gemeten in de peilbuizen, de gemeten bewortelingsdiepte (BEW) en de kritische grondwaterstand voor verdroging (BEW+Zk: rode lijn) zijn weergegeven.

Aan elke meting en berekening zitten onzekerheden. In dit geval lijkt de bepaling van de kritieke zafstand het gevoeligst, omdat niet zeker is of de bodemfysische eigenschappen van gronden in Amelisweerd overeenkomen met de voorbeeldgronden in de Staringreeks. Daar zal altijd variatie in zitten. De onzekerheid die daaruit voortkomt, is te beschouwen als een toetsingsprobleem. De vraag is 
dan: 'Wat is de kans dat een boom ten onrechte als veilig beschouwd wordt en later toch schade blijkt te hebben?' Dat kan zich voordoen als de kritieke z-afstand te groot is ingeschat en in werkelijkheid kleiner is, waardoor de kritieke grondwaterstand eerder wordt onderschreden dan verwacht. Omdat de bodems met een grote kritieke $z$-afstand $(>100 \mathrm{~cm}$ ) over het algemeen ruim binnen de veilige zone zitten, doet deze vraag zich vooral voor bij bodems met een geringere kritieke z-afstand. Om hier zicht op te krijgen, hebben we in Tabel 2 aangegeven hoeveel bomen bij een grondwaterstand als in 2018 voldoende capillaire nalevering krijgen en hoeveel niet. Daarbij is ook beoordeeld wat het effect zou zijn als de kritieke z-afstand $20 \mathrm{~cm}$ groter of kleiner is dan berekend. Het gaat dan om maximaal vijf bomen die onterecht als veilig aangemerkt zouden worden.

Tabel 2 Verdeling van het aantal bomen warbij de grondwaterstand in de zomer van 2018 dieper of ondieper was dan de kritieke diepte. De onzekerheid over de kritieke z-afstand is verwerkt in klassen 2 en 3, waarbij rekening gehouden is met een marge van $20 \mathrm{~cm}$.

\begin{tabular}{rlr} 
Klasse & & Aantal bomen \\
1 & Veilig, ruim binnen kritieke diepte & 14 \\
\hline 2 & Waarschijnlijk veilig, binnen $20 \mathrm{~cm}$ van kritieke diepte & 5 \\
3 & Mogelijk te droog, binnen $20 \mathrm{~cm}$ onder kritieke diepte & 6 \\
\hline 4 & Te droog, meer dan $20 \mathrm{~cm}$ onder kritieke diepte & 5 \\
\hline Totaal & & 30 \\
\hline
\end{tabular}

Bij deze analyse moet wel bedacht worden dat het dus gaat om een mogelijk vochttekort gedurende de periode dat de kritische grondwaterstand onderschreden wordt. In hoeverre dat nadelig is voor de boom zal afhangen van:

- de duur van deze onderschrijding;

- de periode waarin deze optreedt (wel of niet in het groeiseizoen);

- de hoeveelheid bodemvocht die nog als hangwater in de bodemporiën binnen de bewortelingszone beschikbaar is.

Duur en periode van de onderschrijding zijn afhankelijk van de organisatie van de werkzaamheden. De hoeveelheid hangwater is afhankelijk van de bewortelingsdiepte en het vochthoudend vermogen van de bodemlagen en kan voor een kleigrond met een bewortelingsdiepte van $80 \mathrm{~cm}$ al snel meer dan $200 \mathrm{~mm}$ vocht naleveren (Ten Cate et al., 1995D). Bij een verdamping van $2 \mathrm{~mm} / \mathrm{dag}$ is dat voldoende om een periode van 100 dagen te overbruggen. Vooral bij ondiepere beworteling kan dan een probleem optreden, bij een grotere bewortelingsdiepte zijn weinig problemen te verwachten.

\subsection{Autonome bosontwikkeling}

Uit de groeiontwikkeling van de bomen in de afgelopen decennia en uit de resultaten van de verschillende deelonderzoeken en waarnemingen kan de autonome bosontwikkeling worden afgeleid. Naar verwachting gelden de uit het onderzoek getrokken conclusies ook voor het Trapeziumbos ten oosten van de Kromme Rijn. Om dit te valideren, zouden in dit deel van het bos echter meer waarnemingen gemaakt moeten worden. De beschrijving van de autonome bosontwikkeling in deze paragraaf beperkt zich daarom tot het Markiezenbos, ook omdat dit bos direct naast de A27 ligt en hier dus de grootste effecten van de werkzaamheden verwacht kunnen worden.

\subsubsection{De rol van eik en beuk}

Grote eiken horen bij de imposantste en dominantste bomen in het Markiezenbos. De grote en vol uitgegroeide exemplaren behoren tot de oudste bomen van het bos. Hier en daar vallen eiken van deze generatie uit, maar veel exemplaren hebben nog steeds een hoge toekomstverwachting en kunnen nog decennialang een rol binnen het bos vervullen.

In de struiklaag komen echter amper eiken voor. Er is bijna geen verjonging aangetroffen. Mogelijk kiemt de eik op deze gronden slecht en komt door lichtconcurrentie door andere soorten niet van de 
grond. In het Markiezenbos staan verspreid vitaal ogende, grote eiken met kleine kroon en vrij slanke stammen. Deze bomen bleken bij de jaarringanalyse veel ouder te zijn dan hun stamdiameter deed vermoeden. Dit zijn bomen die langzaam groeien, waarschijnlijk onderdrukt door hun beter groeiende buren en bij eventuele vrijgekomen ruimte door het wegvallen van een grote boom in de buurt, (nog) niet met betere groei konden reageren.

Hoewel beuk in voldoende mate zal zijn aangeplant, is ook zijn concurrerende vermogen reden voor de dominante positie in het Markiezenbos. Door het wegvallen van veel essen en de afnemende rol van de eik ontstaat nog meer ruimte voor de beuk. Diverse zeer grote beuken met leeftijden oplopend tot meer dan 150 jaar heersen in hun omgeving. Ook in de wat dichtere opstanden lukt het de jongere beuken om door te groeien tot in het kronendak en hier een toenemende rol te spelen (mede heersend). Het enige aandachtspunt bij beuk is een zekere droogtegevoeligheid (Kunz et al., 2018). Deze uit zich in verminderde groeiprestaties wanneer er lange droogteperiodes zijn in het eerste deel van het groeiseizoen (mei tot juli). Uit de analyses blijkt echter ook dat beuk zich in de jaren daarna weer kan herstellen, wanneer de klimaatcondities weer genormaliseerd zijn.

\subsubsection{De rol van andere boomsoorten}

Gewone esdoorn komt vooral in het westelijke deel van het Markiezenbos veel voor. Esdoorn zaait zich sterk uit in zones waar grote bomen wegvallen en voldoende licht beschikbaar komt.

In de nattere delen van het Markiezenbos zijn in het verleden ook populieren geplant (1960). Van deze beplantingen staan er nog diverse exemplaren in verschillende zones van het bos, zoals in het centrale deel van het Markiezenbos. Deze natte plek wordt niet zo zeer gevormd door hoge grondwaterstanden, maar meer door stagnatie van regenwater op een zeer compacte kleilaag die vrij ondiep begint. De populier is echter ook op z'n retour in het bos.

In de struiklaag is de gewone vogelkers veruit de meest voorkomende soort, naast onder andere hazelaar. Gewone vogelkers slaat sinds een paar jaar massaal op waar essen zijn afgestorven als gevolg van essentaksterfte. De vogelkers staat op veel plaatsen zo dicht op elkaar, dat het bos hier nagenoeg ondoordringbaar is geworden.

\subsubsection{Essentaksterfte en andere aantastingen}

De essentaksterfte heeft in de afgelopen jaren tot uitval van een aanzienlijk aantal essen in het Markiezenbos geleid. Het betreft een schimmelaantasting die in Nederland pas enkele jaren geleden vanuit Noordoost-Europa binnenkwam en voor het eerst in 2010 is vastgesteld. Binnen haar beheer velt de gemeente de exemplaren die afgestorven zijn of als gevolg van de aantasting risico's kunnen veroorzaken voor de bezoekers van het bos.

Het is niet te verwachten dat de ziektedruk in de komende tijd omlaaggaat. Op het moment van dit onderzoek zijn niet alle bomen aangetast. Onduidelijk is in hoeverre dit alsnog gaat plaatsvinden. Voor de essentaksterfte is er tot nu toe geen remedie of behandeling.

De es zal hierdoor haar rol als hoofdboomsoort binnen het bos gedeeltelijk kwijtraken. In zones waar afstervende essen in een gemengde opstand staan, zullen de bomen van andere soorten de vrijkomende ruimte in beslag nemen. Dit is voor een deel door uitbreiding van naburige volwassen bomen. In zones met voornamelijk es kunnen grotere gaten in het bos ontstaan, die niet volledig dichtgroeien door de naburige bomen. Hier zal natuurlijke en spontane verjonging optreden van onder andere gewone vogelkers, tenzij de beheerder hier gerichte herplant uitvoert. Vogelkers kan zo op termijn ontwikkelen tot een tweede boomlaag onder beuk, es en esdoorn. Dit is een bekend verschijnsel in bossen op rijke kleigronden. Ook hazelaar en meidoorn profiteren hiervan mee. De vogelkers biedt wel ruimte voor beuk en esdoorn om zich te vestigen en op termijn de eerste boomlaag te vormen.

Naast de essentaksterfte zijn er vooral verschillende houtparasitaire schimmels aangetroffen die zorgen voor aantastingen bij bomen in Amelisweerd. Uit de veldwaarnemingen blijkt dat de ziektedruk door de honingzwam hier vrij hoog is. Naar verwachting zullen regelmatig bomen conditioneel achteruitgaan of zelfs afsterven als gevolg van een aantasting door de honingzwam of een andere zwam. Dit hoort echter bij een natuurlijke bosontwikkeling en heeft qua omvang een (zeer) beperkte impact op het bos als geheel. 
De iep is als boomsoort grotendeels verdwenen uit het Markiezenbos. De meeste oudere iepen zijn inmiddels afgestorven als gevolg van een aantasting door de iepziekte. Verspreid over Amelisweerd komen jonge iepen voor. De natuurlijke verjonging met zaailingen van iep is beperkt. Ook deze jonge iepen kunnen door de iepziekte worden aangetast. Iep zal daarom een ondergeschikte rol blijven spelen.

\subsubsection{Vernatting en verdroging}

Vernatting is in delen van het bos een probleem. De grond is hier in de wintermaanden regelmatig zompig en er heersen omstandigheden die voor veel boomsoorten ongunstig zijn. Het gaat hierbij vooral om het centrale deel van het Markiezenbos waar de populier is aangeplant. Op basis van het veldonderzoek is geconstateerd dat dit het gevolg is van de zeer compacte kleilaag die op sommige plekken vrij ondiep is aangetroffen. In natte tijden stagneert regenwater op deze laag en kan niet of slechts heel langzaam naar beneden wegsijpelen.

Droogteverschijnselen en -schades bij bomen binnen het Markiezenbos zijn in het verleden niet gemeld of beschreven. Het jaar 2018 was echter een uitzonderlijk jaar door zijn extreem lange droogte, in combinatie met hoge temperaturen gedurende de hele voorzomer en zomer. Tijdens het veldonderzoek is daarom regelmatig gekeken in hoeverre bij bomen symptomen zichtbaar worden die duiden op droogtestress. Hier zijn vanaf eind juli tot en met september de volgende zaken waargenomen:

- Bij de gewone esdoorn was verdroging van blad al vanaf juli zichtbaar. Dit betrof veel jonge en jongvolwassen bomen in het westelijke deel langs de A27 waar de meeste esdoorns staan.

Daarnaast was dit beeld wat later in de zomer en in mindere mate ook bij enkele oudere esdoorns aan de zuidkant van het bos te zien.

- Bij diverse volwassen beuken was te zien dat het blad aan de bovenkant van de kroon vanaf augustus begon te krullen en soms van kleur veranderde. Hier en daar lieten bomen al blad uit de bovenste kroondelen vallen, terwijl de onderste kroondelen nog groen en volledig functioneel waren.

- Bij eik en es zijn geen opvallende uitwendige symptomen aan blad waargenomen die gerelateerd kunnen worden aan droogtestress.

Dit beeld wordt ook bevestigd door de jaarringanalyse. De groei van de onderzochte bomen nam alleen duidelijk af in extreme droogtejaren zoals 1959, 1976 en 1996. De groei van deze bomen herstelde in de jaren na deze droogtejaren. Ook 2018 was extreem droog, maar tijdens de monstername in augustus was de jaarring nog niet volgroeid om de effecten ervan eenduidig vast te stellen. Verder kunnen uit de terugkoppeling met neerslaggegevens conclusies getrokken worden wat betreft de effecten van veel of weinig vocht gedurende verschillende delen van het jaar. Uit de reactie van de bomen op de natuurlijke schommelingen binnen het klimaat kan worden afgelezen dat er sprake is van een systeem met in de basis een goede plasticiteit ten aanzien van schommelingen en veranderingen. Dit duidt erop dat het grondwatersysteem relatief goed gebufferd is, hetgeen uit de hydrologische analyses is bevestigd.

\subsubsection{Toekomstige bosontwikkeling}

Uitgaande van actuele processen die in het bos spelen, gecombineerd met leeftijd van de hoofdboomsoorten, is de verwachting voor de komende paar decennia dat het bos op hoofdlijnen gedomineerd zal blijven door eik en beuk. Het aandeel eik zal geleidelijk iets kleiner kunnen worden, maar ook onder beuk kan sterfte door ouderdom gaan optreden, om de simpele reden dat beuk veel minder oud kan worden dan eik. De afname van es zal vanwege de essentaksterfte verder toenemen, maar es zal nog niet helemaal verdwijnen.

Afhankelijk van het aantal droogtejaren in de komende 10-20 jaar kan de boomsoortensamenstelling nog iets verschuiven. Beuk is het gevoeligst voor droogte en kan dus worden getroffen wanneer het aantal droogtejaren binnen een kort tijdsbestek toeneemt.

Omdat de drie hoofdboomsoorten wel wat kwetsbaar zijn door leeftijd, ziekte of droogtegevoeligheid, zouden andere soorten een toenemende rol kunnen gaan spelen. Gewone esdoorn is een kanshebber gezien het gemak waarmee deze zich verjongt, maar ook gewone esdoorn is kwetsbaar in tijden van 
droogte. Wanneer extreemjaren zoals 2018 toch een uitzondering blijken te zijn, wordt verwacht dat de boomsoortensamenstelling alleen drastisch kan veranderen door toenemende sterfte onder de es.

\subsection{Conclusies}

De bovengrond in Amelisweerd bestaat uit lichte klei op een zwaardere kleilaag die op wisselende diepten voorkomt. Deze zwaardere kleilaag kan erg compact zijn. Onder het kleipakket komt op eveneens wisselende diepte een zandlaag voor.

De opbouw en textuur van de verschillende bodemlagen in Amelisweerd kan op zeer korte afstand erg variëren.

De beworteling concentreert zich in de minder zware kleilagen, maar dringt ook wel door tot in de zwaardere klei, maar waar de zandlaag begint, stopt ook de beworteling. De kritische afstand Zk wisselt sterk. Er is sprake van een gebufferd grondwatersysteem door oeverinfiltratie vanuit de Kromme Rijn en vanuit de regionale kwel vanuit de Heuvelrug.

De kritische z-afstand is niet overal groot genoeg om in langer durende droogteperioden voldoende nalevering van bodemvocht te garanderen.

De uiterlijke kenmerken voor conditie en vitaliteit van de bomen zegt niets over de groei van de bomen en hun reacties op klimaat (neerslag/droogte).

Uit groeianalyses blijkt dat de bomen geen negatieve groeireactie hebben vertoond op bekende grondwaterstanddalingen ten tijde van de aanleg van de A27 of peilwijzingen van de Kromme Rijn. Wel vertonen de bomen een groeidepressie tijdens de extreme droogtejaren van o.a. 1959, 1976 en 1996. Met name beuk blijkt gevoelig. De groei van de bomen is na de droogtejaren weer hersteld. Op basis van de verzamelde gegevens is de verwachting voor de komende paar decennia dat het bos op hoofdlijnen gedomineerd zal blijven door eik en beuk. Het aandeel eik zal geleidelijk iets kleiner kunnen worden, maar ook onder beuk kan sterfte door ouderdom gaan optreden, om de simpele reden dat beuk veel minder oud kan worden dan eik. Daarnaast is beuk het gevoeligst voor droogte en kan worden getroffen wanneer het aantal droogtejaren zou toenemen. De afname van es zal verder toenemen, maar es zal (nog) niet helemaal verdwijnen. 


\section{Literatuur}

Albers, L.H., 2009. Amelisweerd en Rhijnauwen. Cultuurhistorische onderzoek. Albers Adviezen Historische Parken Utrecht.

Cate ten, J.A.M., Van Holst, A.F., Kleijer, H. \& Stolp, J., 1995. Handleiding bodemgeografisch onderzoek; Richtlijnen en voorschriften; Deel A: Bodem. Wageningen, SC-DLO. Technisch document 19A.

Cate ten, J.A.M., Van Holst, A.F., Kleijer, H. \& Stolp, J., 1995. Handleiding bodemgeografisch onderzoek; Richtlijnen en voorschriften; Deel D: Interpretatie van bodemkundige gegevens voor diverse vormen van bodemgebruik. Wageningen, SC-DLO. Technisch document 19D.

Grift, B. van der, S. Clerkx, A. Veldhuizen, B. van Delft, J. Hilbert, J. Schellekens, L. Bos-Burgering, H. Bootsma, D. van Ree, 2018. A27 Ring Utrecht foliebakconstructie- Effecten Waardevol Groen. Fase 1: inventarisatie en analyse beschikbare gegevens. Intern rapport Deltares.

Grift, B. van der, et al. (In voorbereiding). A27 Amelisweerd - Natuur/Effecten groen fase 2a. Utrecht Deltares.

Jörg Kunz, Georg Löffler \& Jürgen Bauhus, 2018. Minor European broadleaved tree species are more drought-tolerant than Fagus sylvatica but not more tolerant than Quercus petraea. Forest Ecology and Management, Volume 414, 15 April 2018, Pages 15-27.

(https://doi.org/10.1016/j.foreco.2018.02.016)

Maes, B., 2009. Historische dendrologie Landgoederen Oud en Nieuw Amelisweerd en Rhijnauwen. Utrecht, Ecologisch Adviesbureau Maes.

Roloff, A., 2001. Baumkronen - Verständnis und praktische Bedeutung eines komplexen Naturphänomens. Verlag E. Ulmer, Stuttgart, 164 S.

Wirdum, G. van,1981. Ecologische beschrijving van Amelisweerd in verband met de aanleg van de A27. Samenvatting van de basisrapporten met betrekking tot de uitgangssituatie. Leersum, RINrapport $81 / 11$ 


\section{Bijlage 1 Bodemkundige gegevens}

De door de bodemkundigen gehanteerde nummering van de bomen wijkt iets af van de nummers die bij andere onderdelen zijn gebruikt. In onderstaande tabel gemerkte bomen X1 en X2 zijn verder zonder de letteraanduiding boom 1 en boom 2 genoemd. Het gaat hierbij wel om dezelfde combinaties van bodem en profielkuil. 


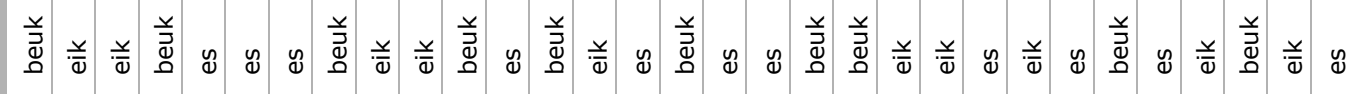

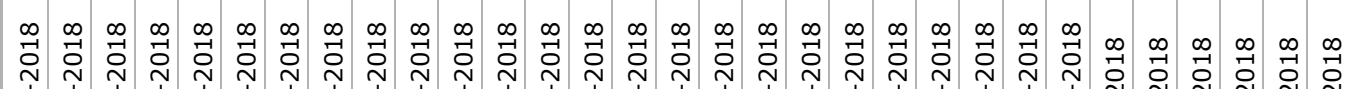

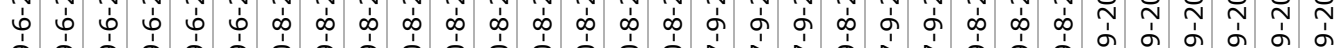

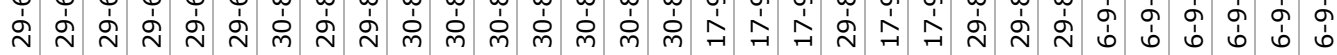

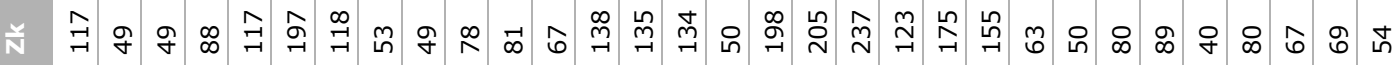

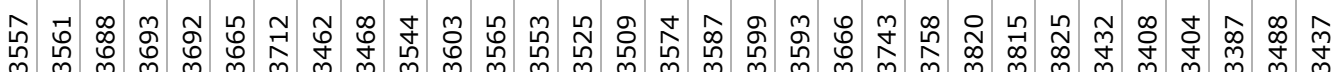

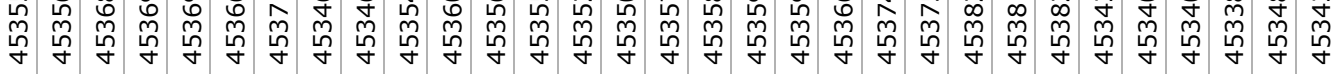

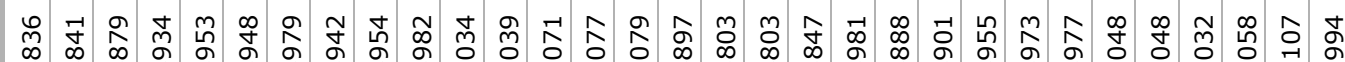

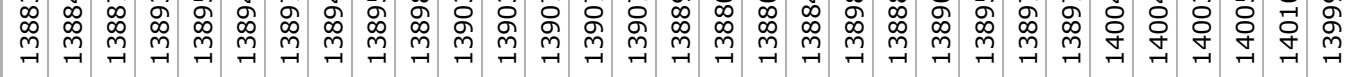

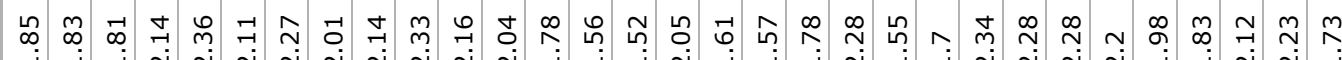
ti

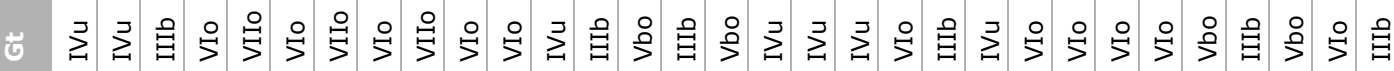

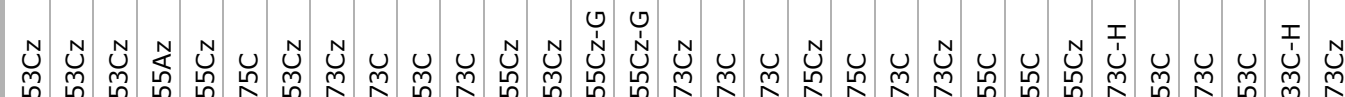

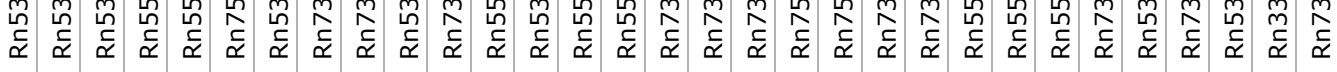

$\circ$

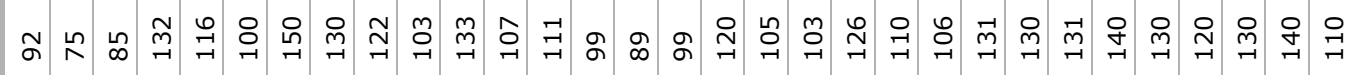

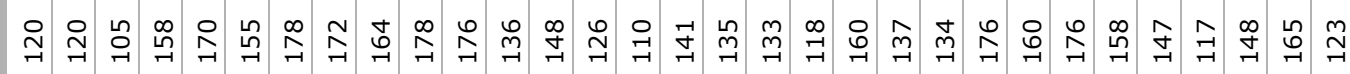

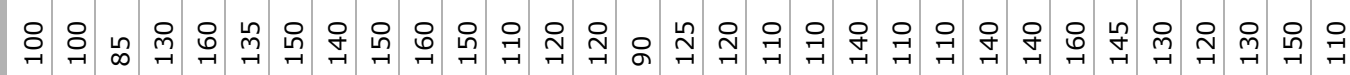

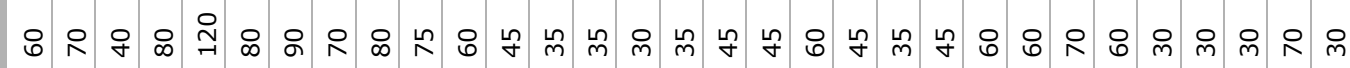

盖

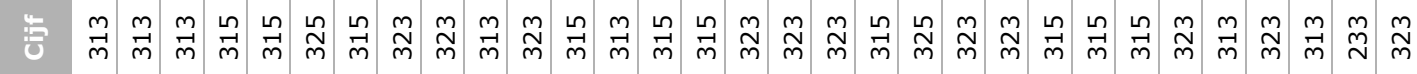

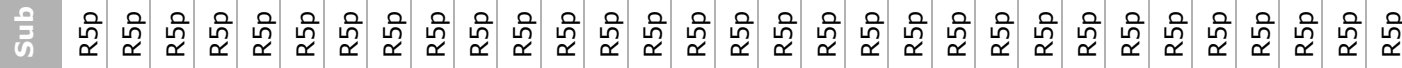

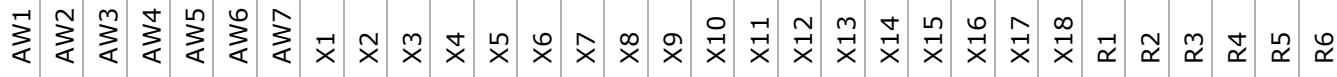


年织识织

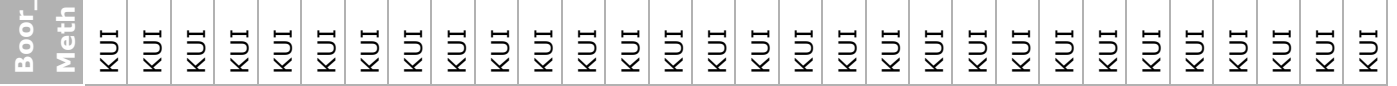
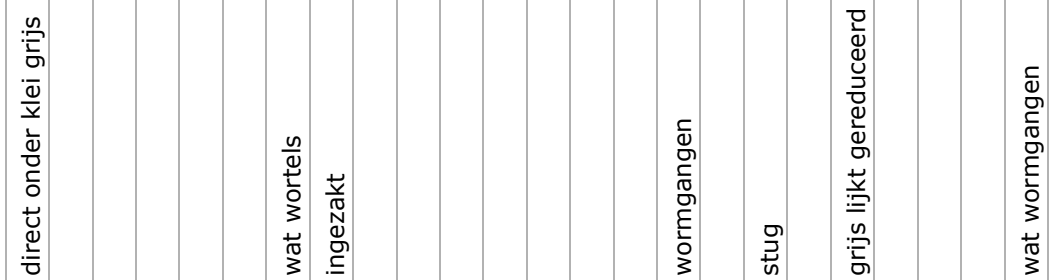

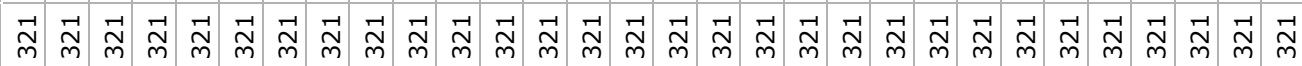
is

$\begin{array}{llllllllll}0 & 0 & \text { in } & \text { in } & \text { in } & 0 & 0 & 0\end{array}$

Ln $\ln 6$

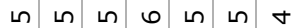

$\ln \operatorname{Ln} 6-1$

$\frac{1}{2} \frac{5}{2}$

$\frac{\underline{y}}{10}$

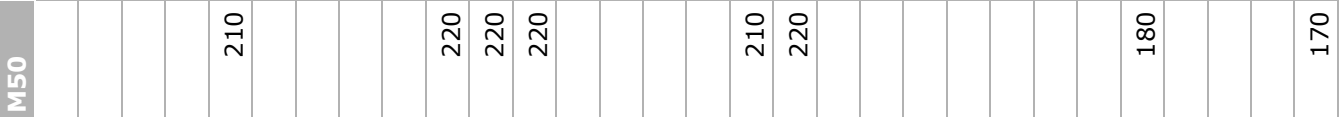

냉 要

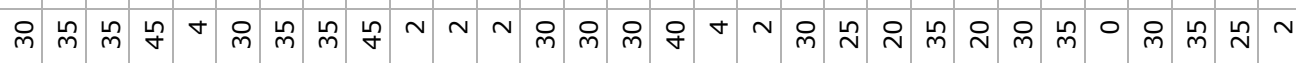

\section{焉}

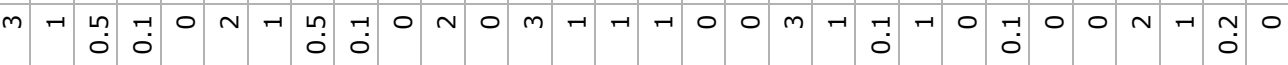

핳

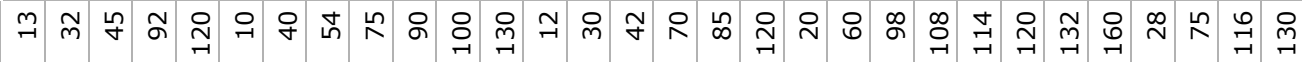
E

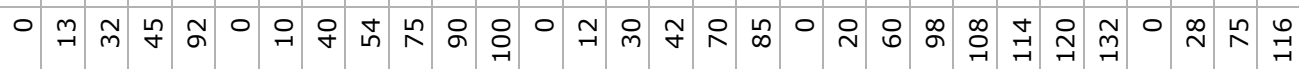

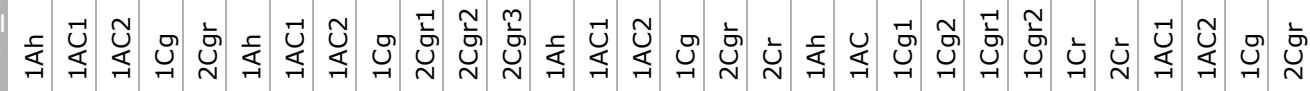

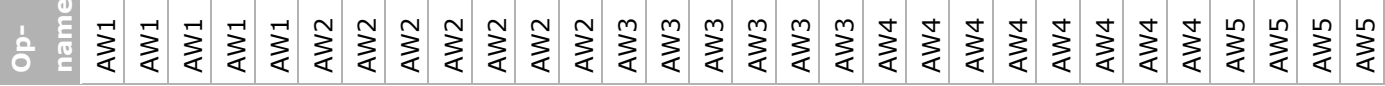




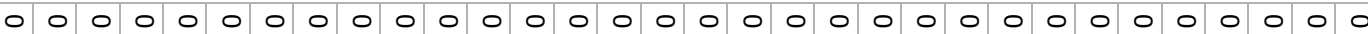

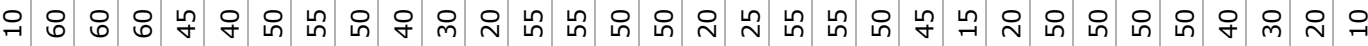

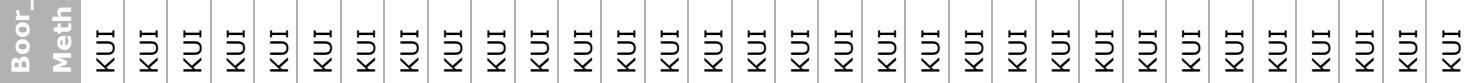

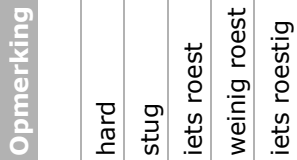

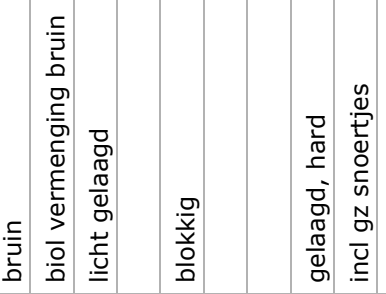

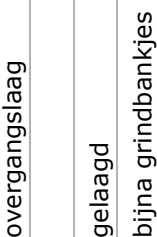

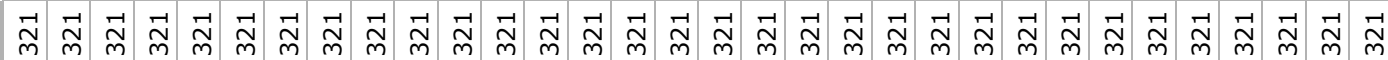
\&

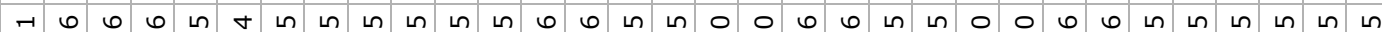
$\frac{1}{2} \frac{5}{2}$

$\stackrel{4}{\stackrel{1}{1}}$

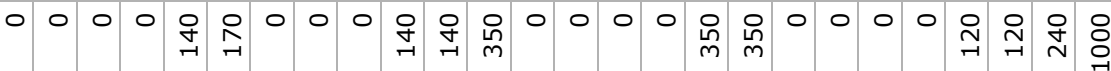

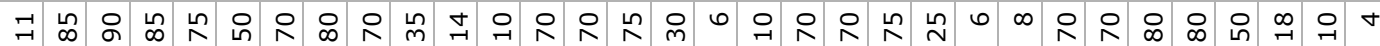
g

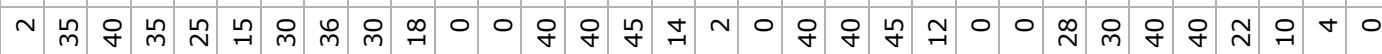

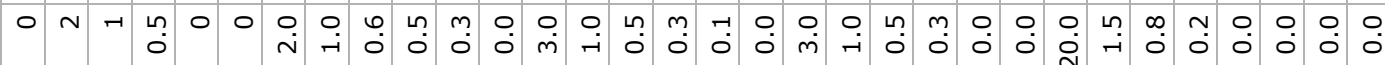

잏

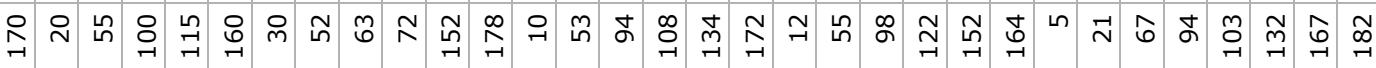

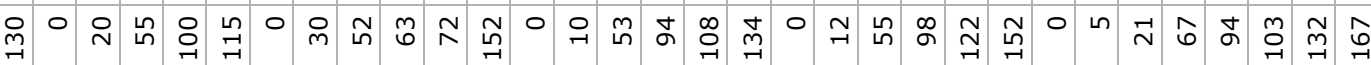

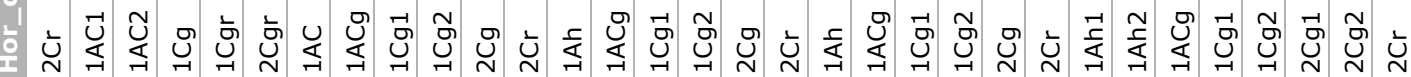

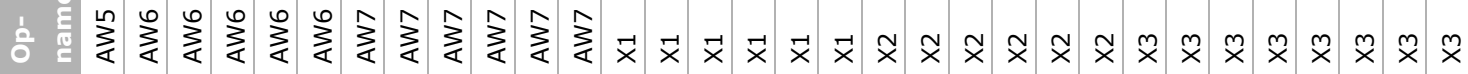




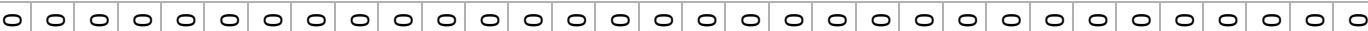

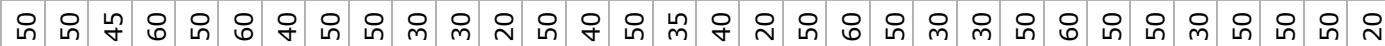

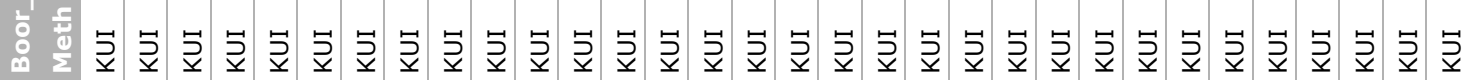

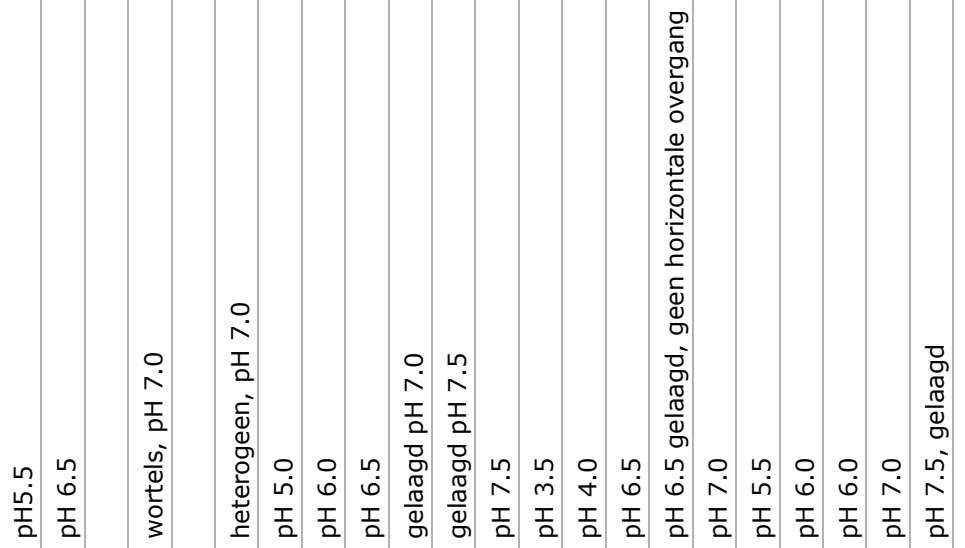

$\overline{0}$
$\frac{\pi}{\pi}$
$\frac{\pi}{\sigma}$

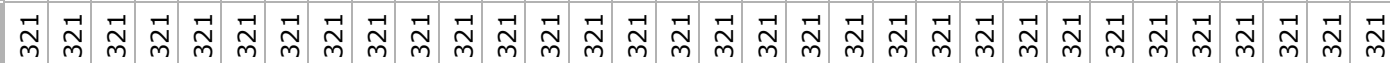
is

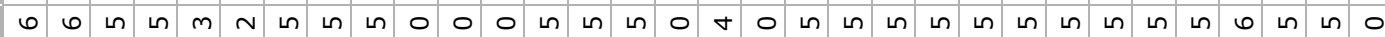
$\frac{1}{2} \frac{1}{2}$

퐁

0 0 0 :

$\frac{10}{2}$

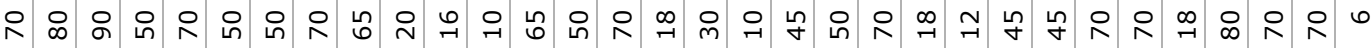
毒

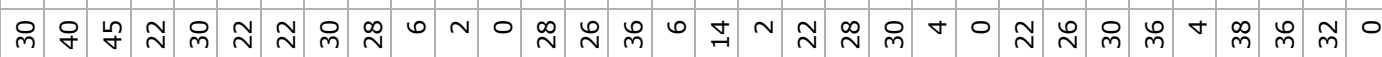

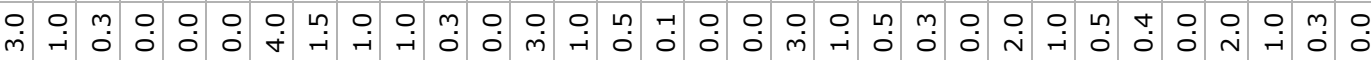

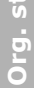

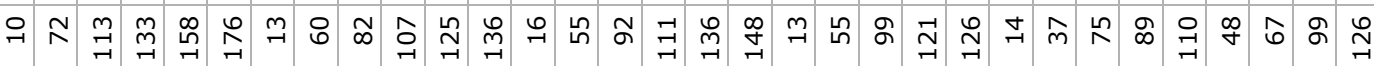

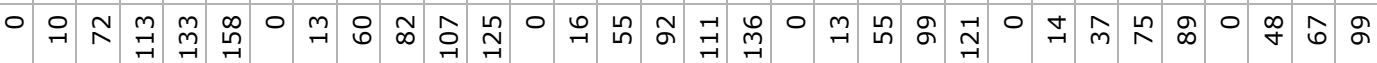

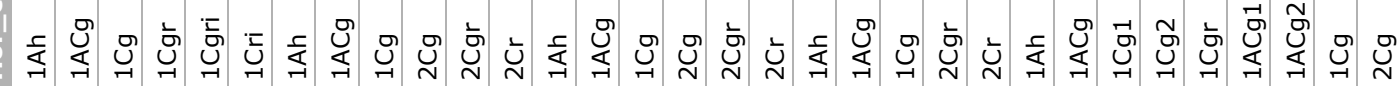

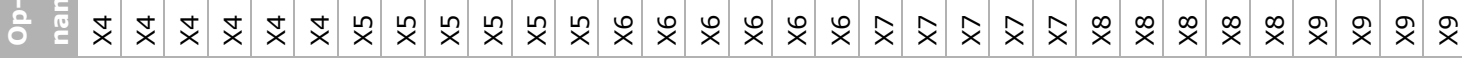




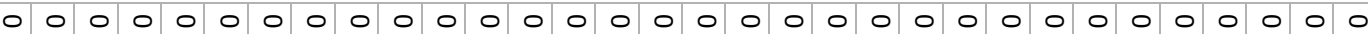

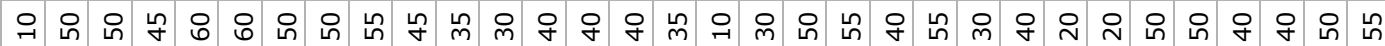

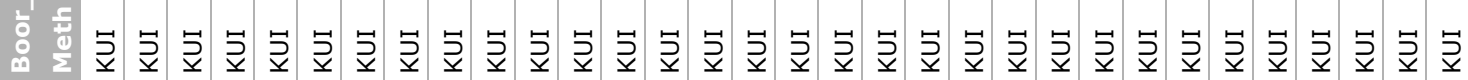
นึ.

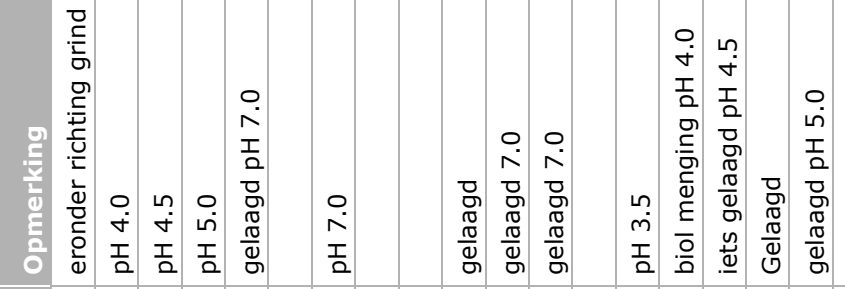

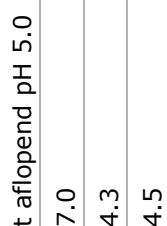

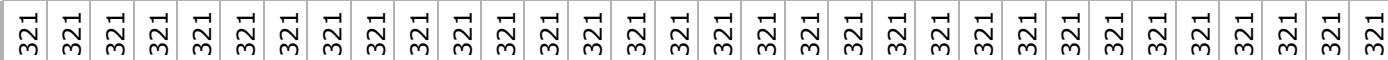
i

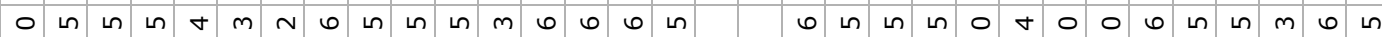
$\frac{1}{2} \frac{1}{2}$

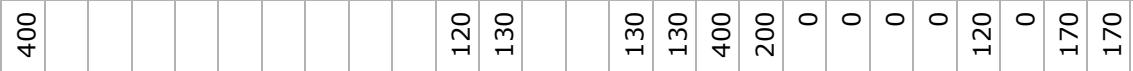

tron 过

○

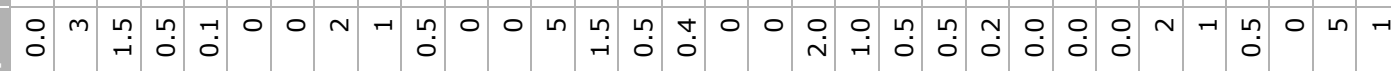
힌

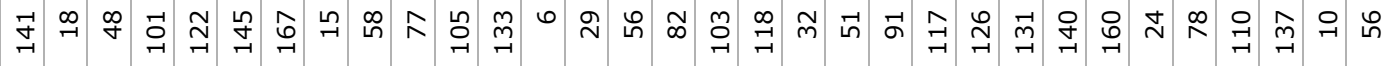

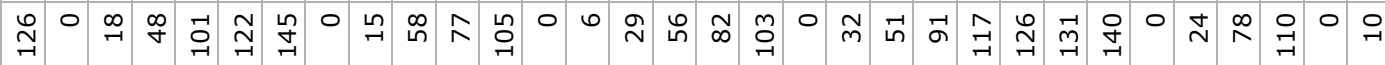

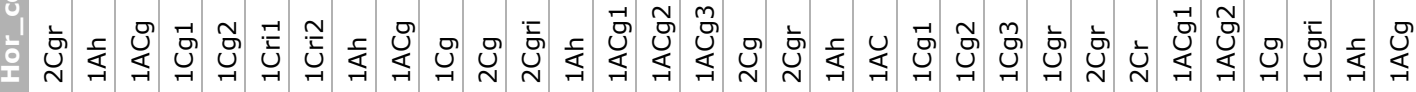

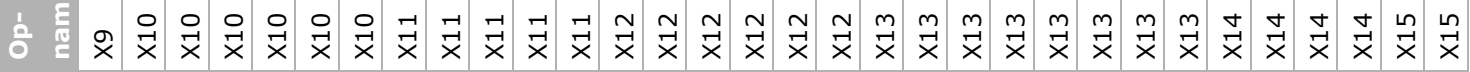




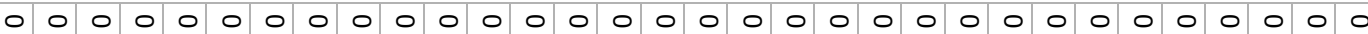

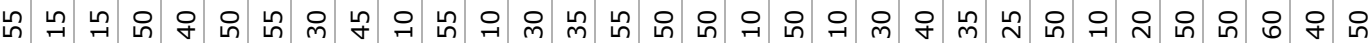

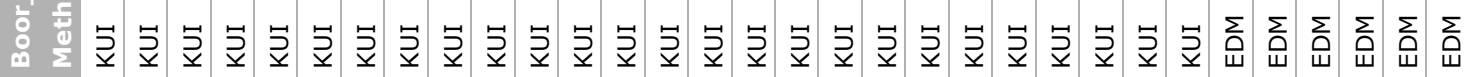
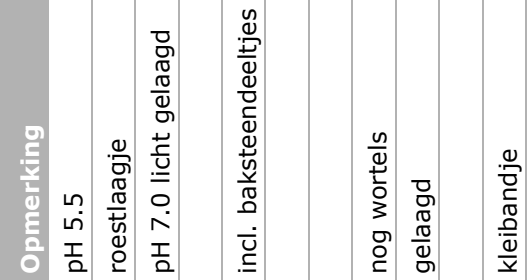

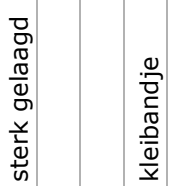

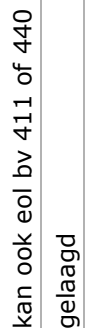

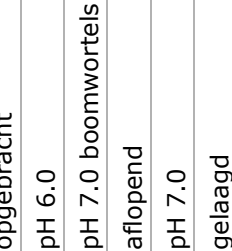

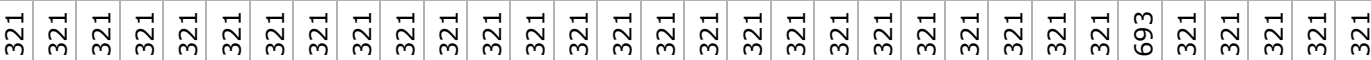
is

เn

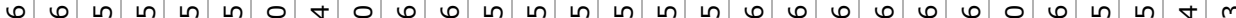

d

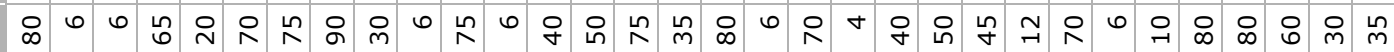

曹

d 0 ○

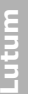

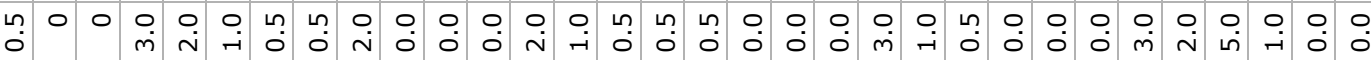

핳

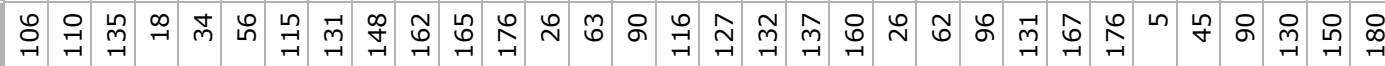

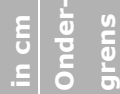

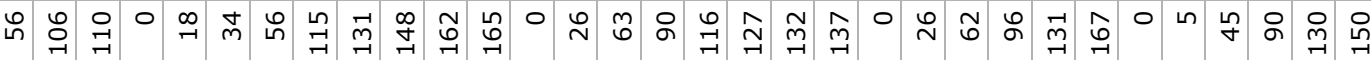

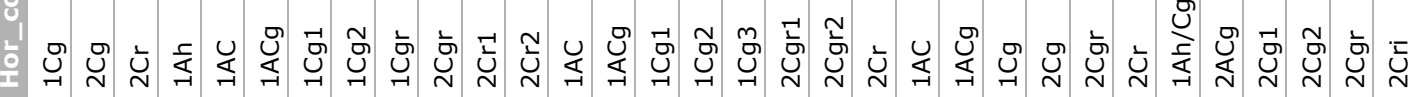

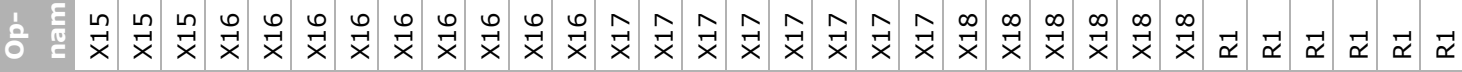




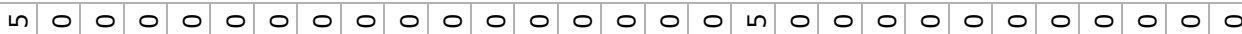

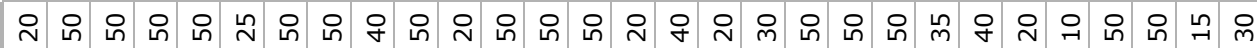

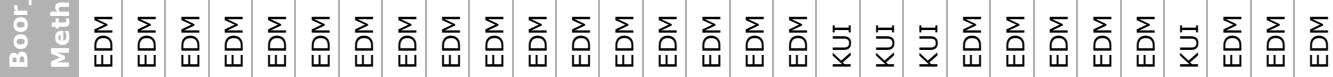

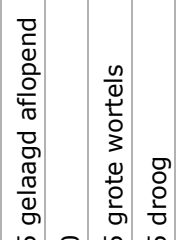

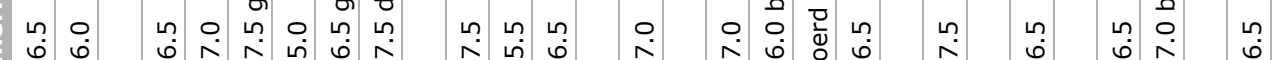

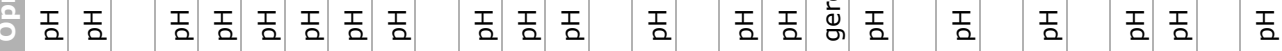

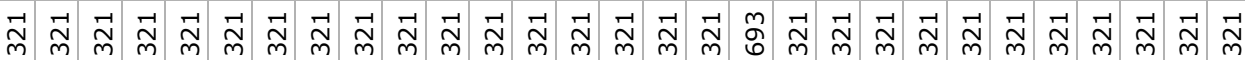
is

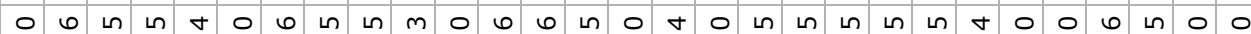
$\frac{1}{2} \frac{5}{2}$

$\frac{1}{10}$

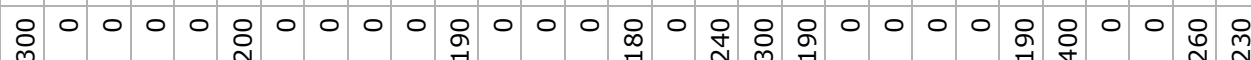

○ 잉

要

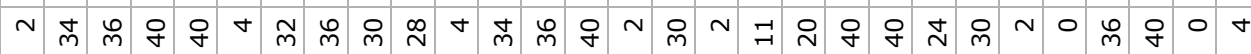

急

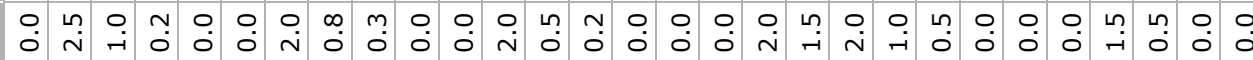

울

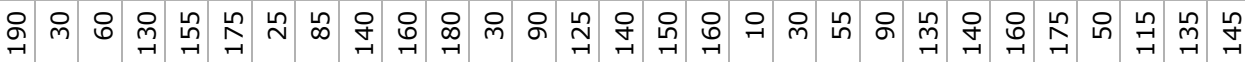

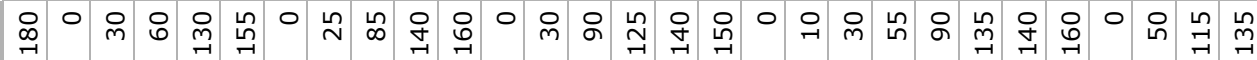

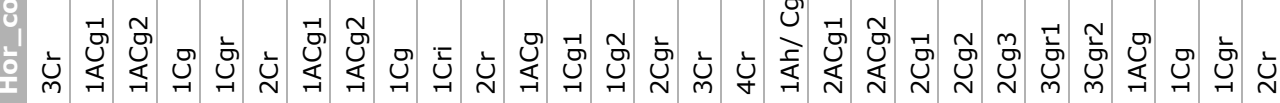

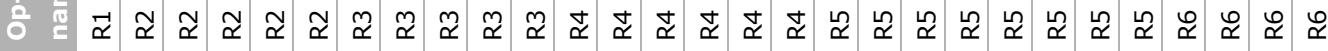




\section{Bijlage 2 Boomgegevens}

Deze tabel bevat de samenvattende beschrijving van de vitaliteitskenmerken van de onderzochte bomen. 


\begin{tabular}{|c|c|c|c|c|c|c|}
\hline 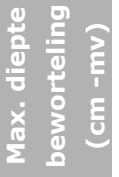 & $\stackrel{\circ}{\vec{r}}$ & $\bowtie$ & $\stackrel{n}{\stackrel{\leftrightarrow}{r}}$ & $\underset{-}{\circ}$ & 억 & $\underset{\sim}{\text { I }}$ \\
\hline 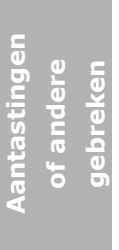 & & & & 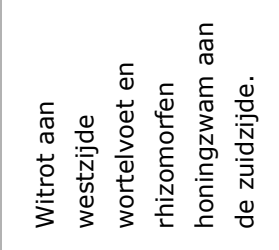 & & \\
\hline 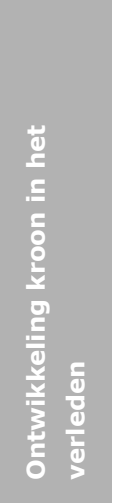 & 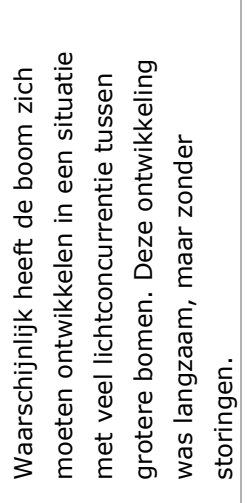 & 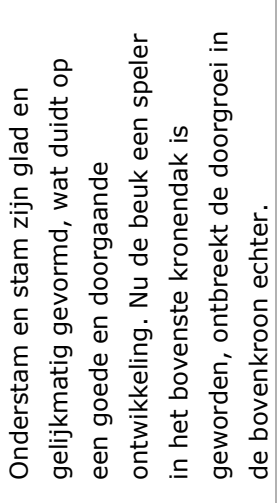 & 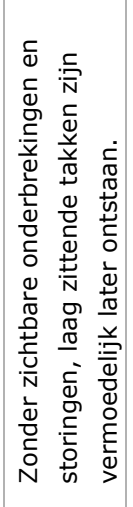 & 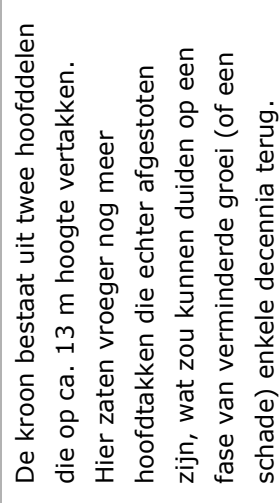 & 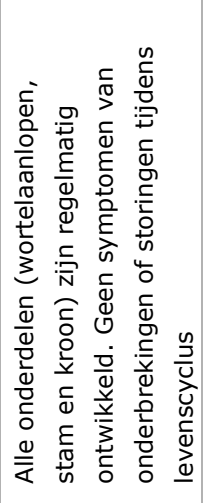 & 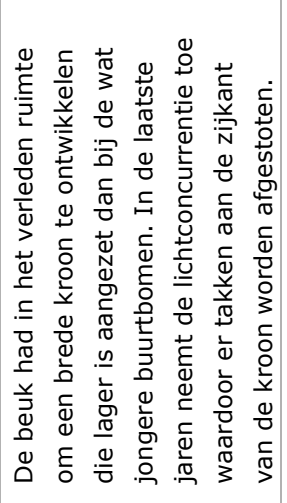 \\
\hline 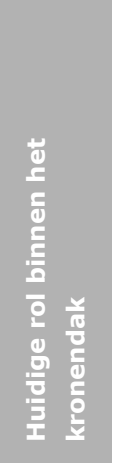 & 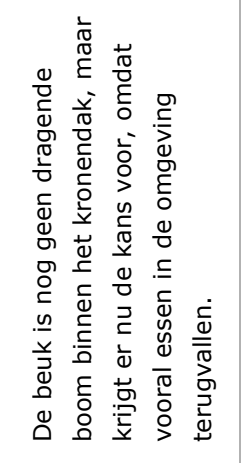 & 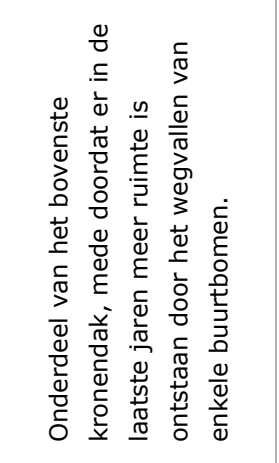 & 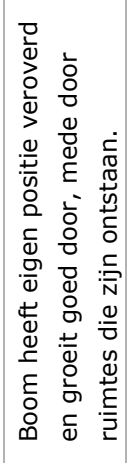 & 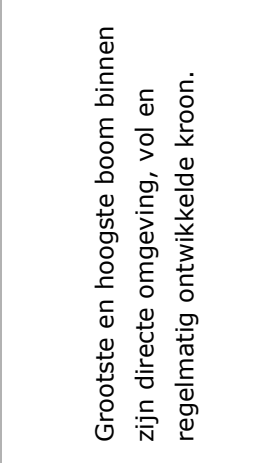 & 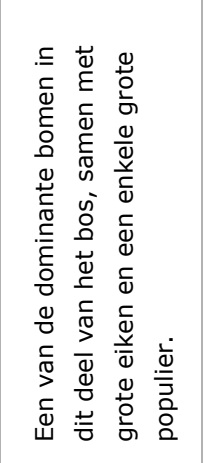 & 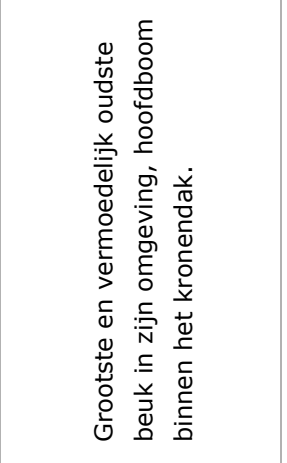 \\
\hline 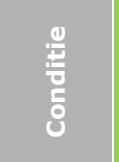 & $\begin{array}{l}\bar{d} \\
\stackrel{\sigma}{\sigma}\end{array}$ & $\begin{array}{l}\frac{0}{0} \\
\frac{0}{0} \\
\frac{0}{0} \\
\frac{0}{0} \\
>\end{array}$ & $\begin{array}{l}\stackrel{\square}{\Phi} \\
\stackrel{\sigma}{\sigma}\end{array}$ & $\begin{array}{l}\frac{0}{0} \\
\frac{0}{0} \\
\frac{0}{0} \\
\frac{0}{0} \\
>\end{array}$ & $\begin{array}{l}\frac{0}{0} \\
\frac{0}{0} \\
\frac{0}{0} \\
\frac{0}{0} \\
>\end{array}$ & $\begin{array}{l}\frac{0}{0} \\
\frac{0}{0} \\
\frac{0}{0} \\
\frac{0}{7}\end{array}$ \\
\hline 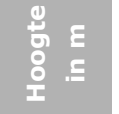 & $\stackrel{\sim}{\sim}$ & $\stackrel{\sim}{\sim}$ & $\stackrel{\llcorner}{\sim}$ & 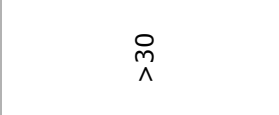 & 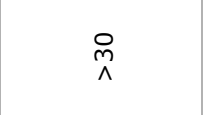 & mे \\
\hline 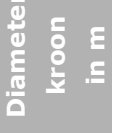 & $\stackrel{m}{\rightarrow}$ & 0 & $\sigma$ & 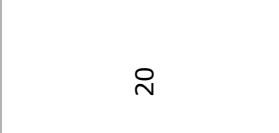 & $\stackrel{n}{\sim}$ & $\underset{1}{0}$ \\
\hline 동 & g & $\vec{\gamma}$ & $\vec{\gamma}$ & $\vec{F}$ & $\stackrel{m}{-1}$ & $\stackrel{\infty}{\underset{7}{二}}$ \\
\hline . & 总 & 哇 & 总 & 惫 & 惫 & 量 \\
\hline ¿ & $\sigma$ & $\approx$ & $\frac{3}{4}$ & $\bullet$ & -1 & $\vec{\alpha}$ \\
\hline
\end{tabular}




\begin{tabular}{|c|c|c|c|c|c|c|}
\hline 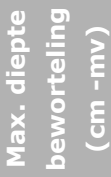 & 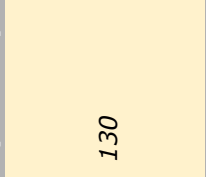 & 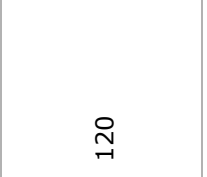 & 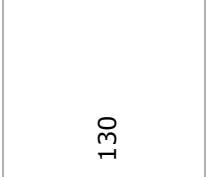 & ঃ & 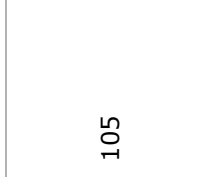 & 8 \\
\hline 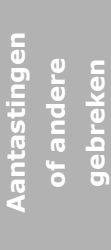 & & 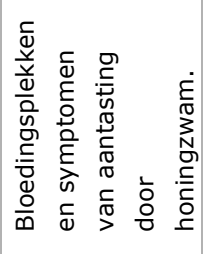 & & & & \\
\hline 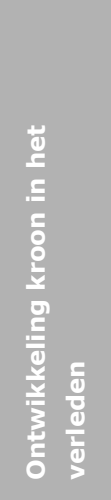 & 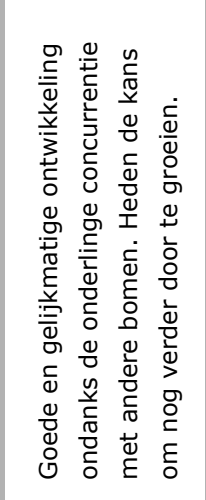 & 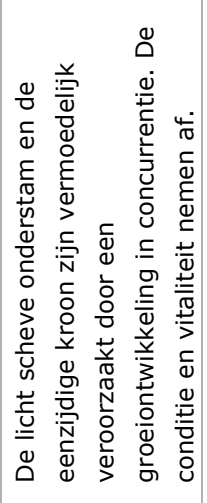 & 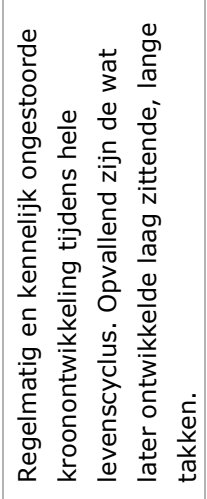 & 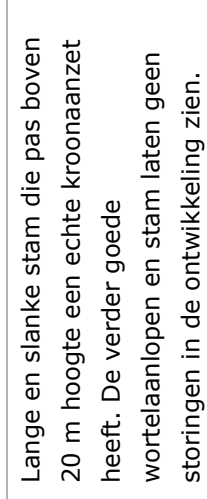 & 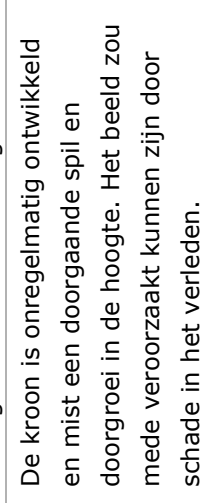 & 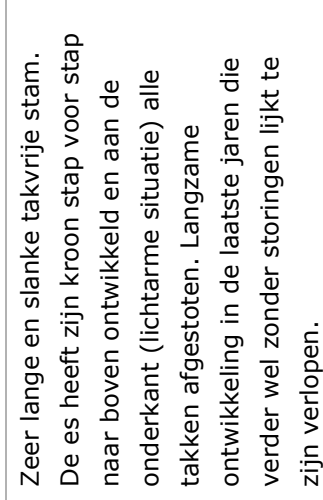 \\
\hline 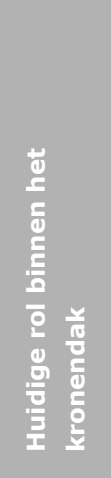 & 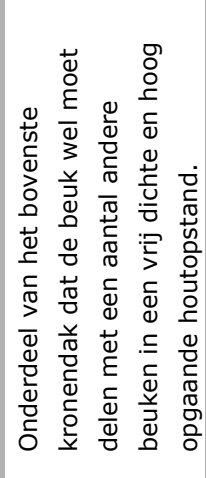 & 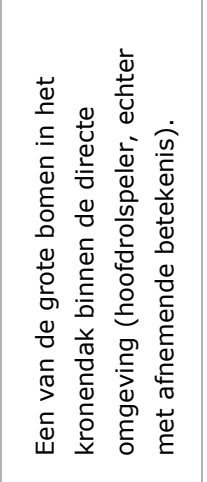 & 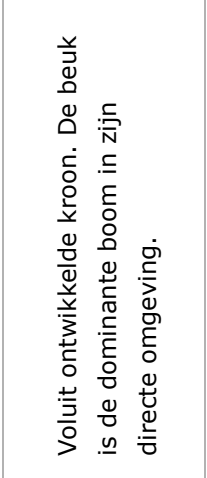 & 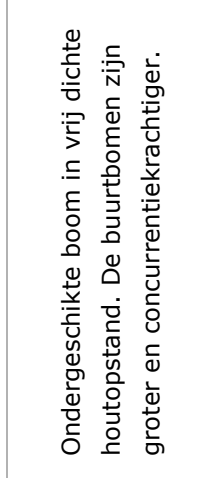 & 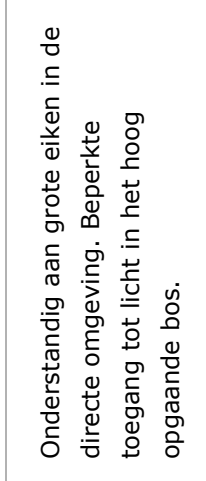 & 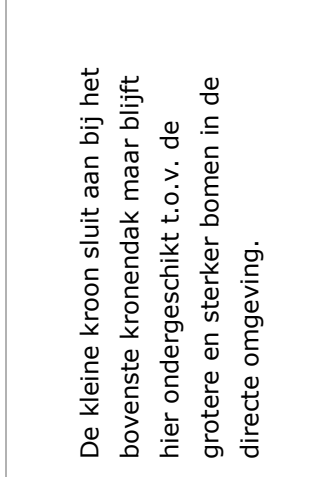 \\
\hline 훙 & 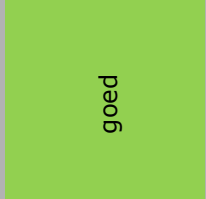 & $\begin{array}{l}\frac{0}{0} \\
\frac{0}{0} \\
\frac{0}{0} \\
\frac{0}{9}\end{array}$ & 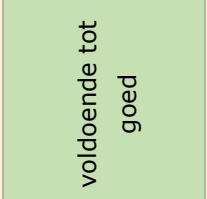 & $\begin{array}{l}\frac{0}{0} \\
\frac{0}{0} \\
\frac{0}{0} \\
\frac{0}{7}\end{array}$ & 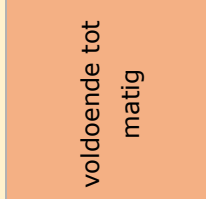 & $\begin{array}{l}\frac{0}{0} \\
\frac{\bar{V}}{0} \\
\frac{0}{0} \\
\end{array}$ \\
\hline 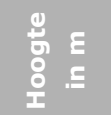 & $\begin{array}{l}\stackrel{p}{m} \\
\stackrel{+}{N}\end{array}$ & 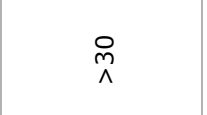 & 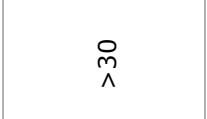 & $\stackrel{\circ}{\wedge}$ & $\stackrel{\text { N }}{\text { s. }}$ & $\stackrel{0}{\wedge}$ \\
\hline 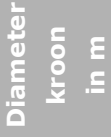 & 욱 & 궁 & $\stackrel{0}{\circ}$ & n & $\infty$ & 0 \\
\hline 동 & in & 志 & ָ̃ & $\mathcal{F}$ & $\vec{m}$ & $\grave{\curvearrowright}$ \\
\hline 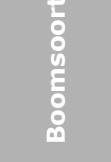 & 恣 & 焉 & 焉 & 恣 & 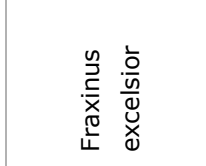 & 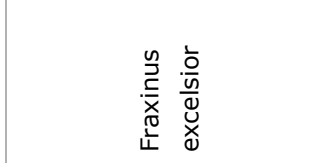 \\
\hline$:$ & $\stackrel{\ddagger}{\simeq}$ & $\stackrel{m}{\rightarrow}$ & $\sum_{\frac{\alpha}{4}}^{+}$ & $a$ & $\vec{F}$ & $\infty$ \\
\hline
\end{tabular}




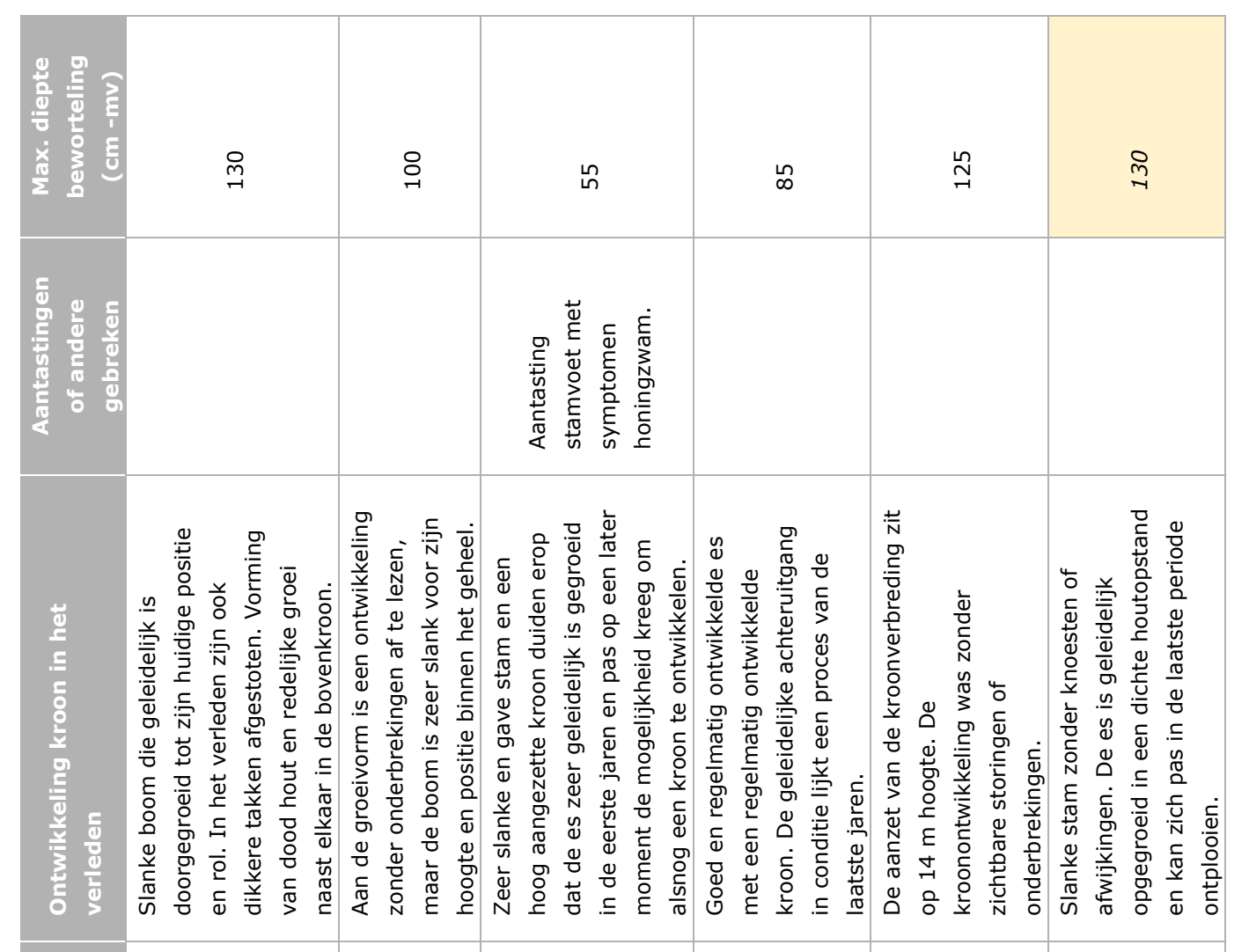

\begin{tabular}{|c|c|c|c|c|c|c|}
\hline 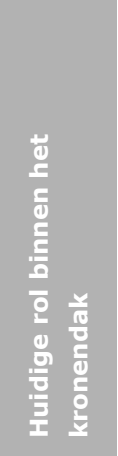 & 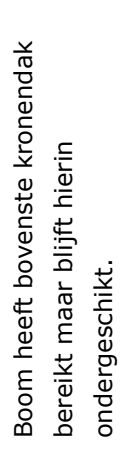 & 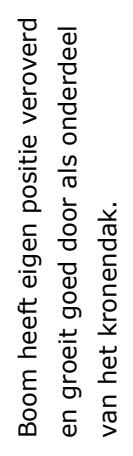 & 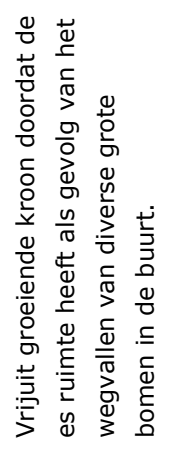 & 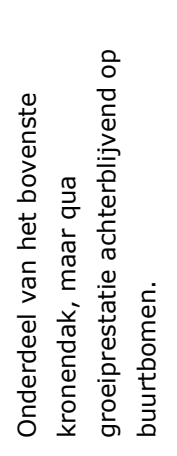 & 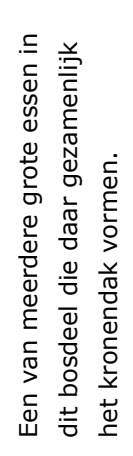 & 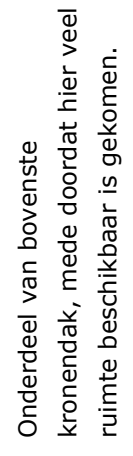 \\
\hline 8ี & $\begin{array}{l}\frac{0}{0} \\
\frac{\bar{d}}{0} \\
\frac{0}{0} \\
\frac{0}{>}\end{array}$ & $\begin{array}{l}\frac{0}{0} \\
\frac{0}{0} \\
\frac{0}{0} \\
\frac{0}{0}\end{array}$ & $\begin{array}{l}\frac{0}{0} \\
\frac{0}{\Phi} \\
\frac{0}{0} \\
\frac{0}{0}\end{array}$ & 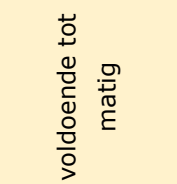 & $\begin{array}{l}\frac{0}{0} \\
\frac{\overline{0}}{0} \\
\frac{0}{0} \\
\frac{0}{0}\end{array}$ & $\begin{array}{l}\frac{0}{0} \\
\frac{0}{0} \\
\frac{0}{0} \\
\frac{0}{3}\end{array}$ \\
\hline 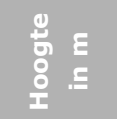 & $\stackrel{\circ}{\wedge}$ & $\stackrel{\underset{N}{E}}{\Lambda}$ & $\stackrel{\text { m }}{ }$ & $\stackrel{\text { pे }}{ }$ & $\stackrel{\substack{n \\
\Lambda}}{\Lambda}$ & 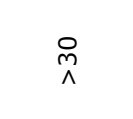 \\
\hline 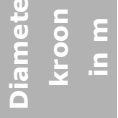 & 웅 & $\sigma$ & $\infty$ & $a$ & $\stackrel{\Delta}{\vec{\prime}}$ & $\stackrel{0}{\rightarrow}$ \\
\hline 㕆 $\overline{0}$ & \& & $\stackrel{m}{m}$ & q & 占 & 藏 & 占 \\
\hline & 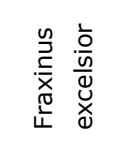 & 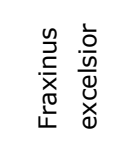 & 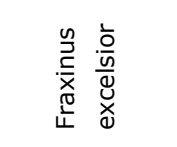 & 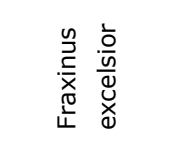 & 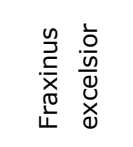 & 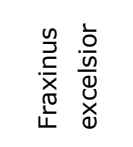 \\
\hline ه. & $\stackrel{\infty}{\rightarrow}$ & $\sum_{4}^{3}$ & \& & $\stackrel{-}{\longrightarrow}$ & $\sum_{<}^{n}$ & $\widetilde{\alpha}$ \\
\hline
\end{tabular}




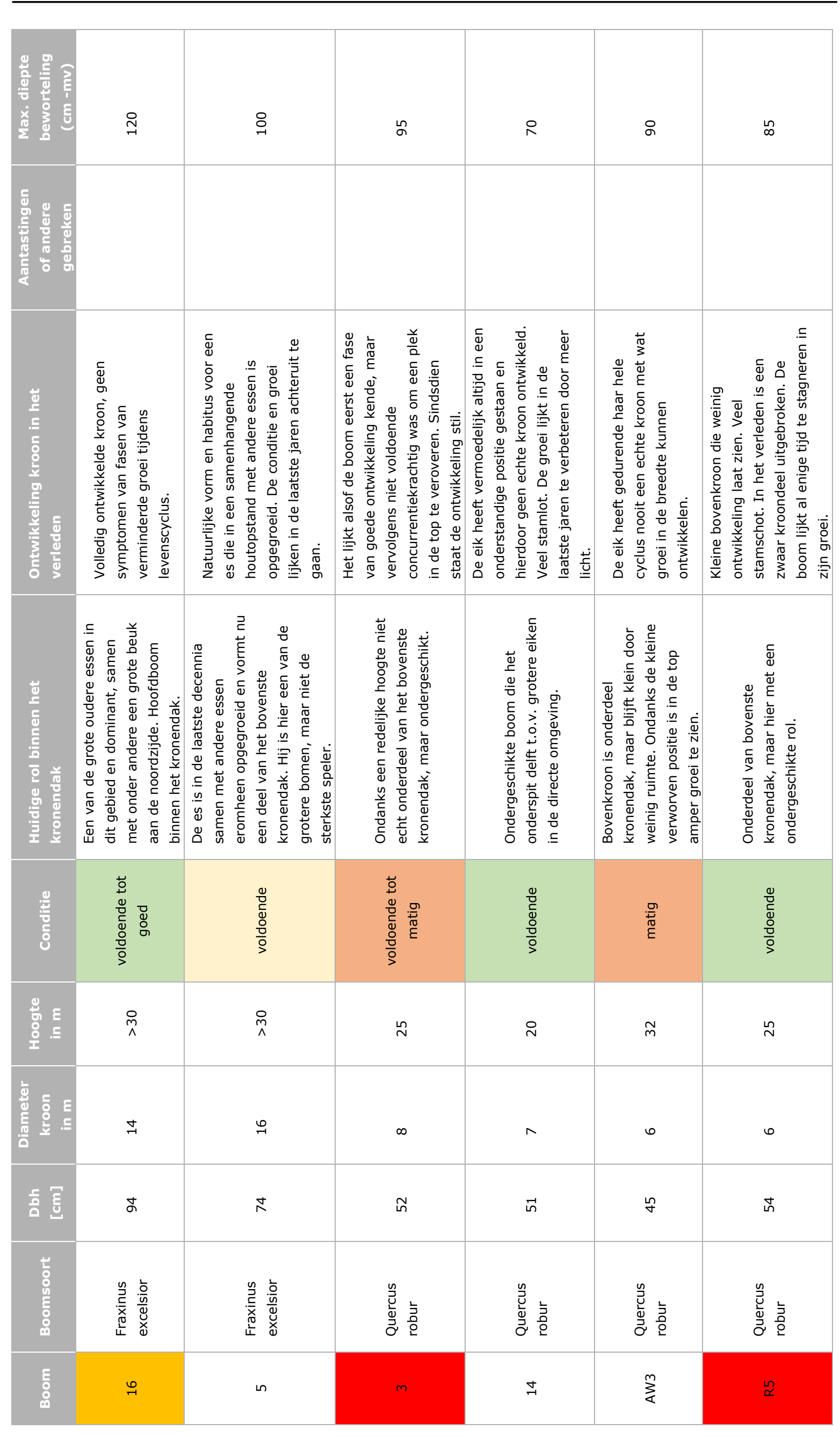




\begin{tabular}{|c|c|c|c|c|c|c|}
\hline 주 & $R$ & 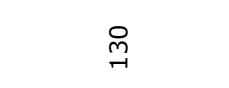 & $\stackrel{\text { 夏 }}{1}$ & : & $\stackrel{n}{n}$ & 유 \\
\hline & & & & & 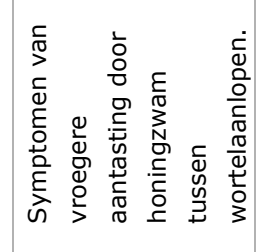 & \\
\hline 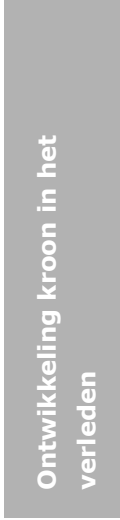 & 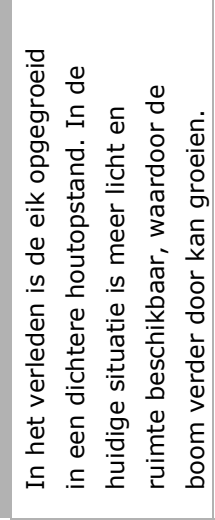 & 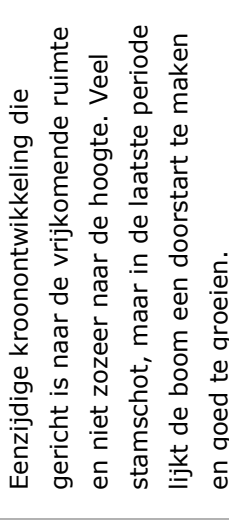 & 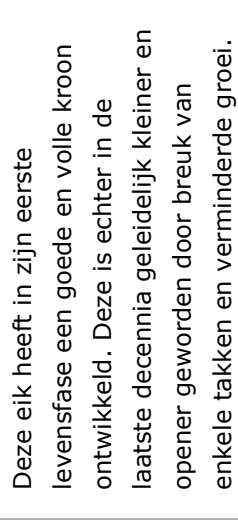 & 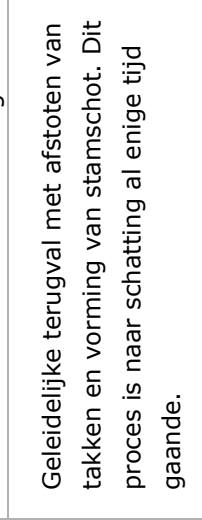 & 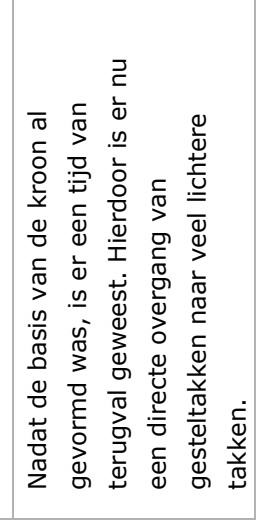 & 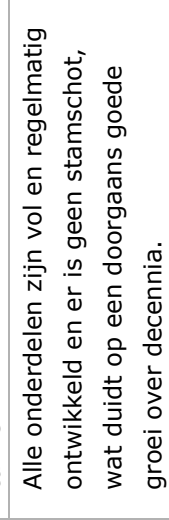 \\
\hline 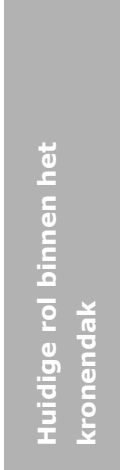 & 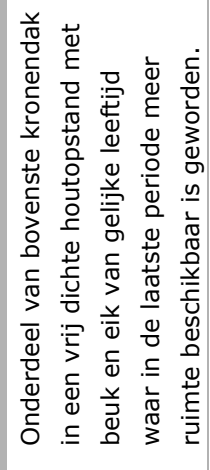 & 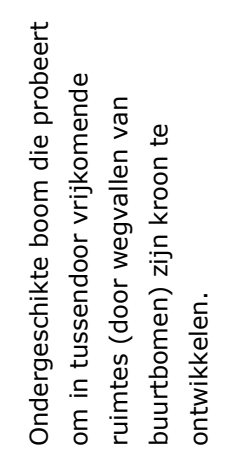 & 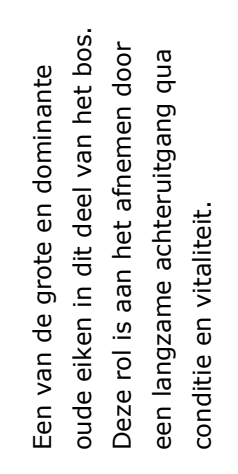 & 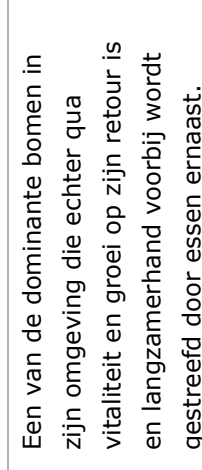 & 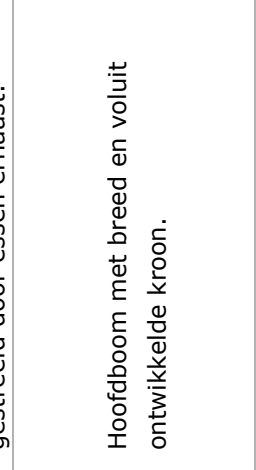 & 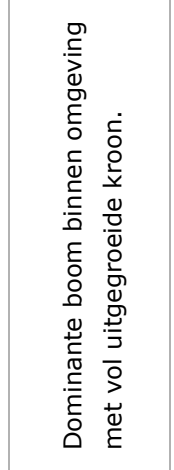 \\
\hline & $\begin{array}{l}\frac{0}{0} \\
\text { एँ } \\
\frac{0}{9} \\
\end{array}$ & 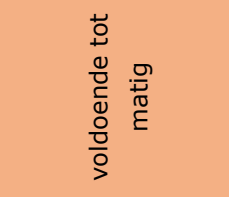 & 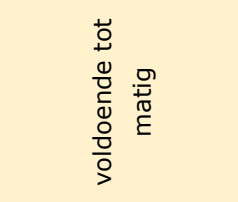 & 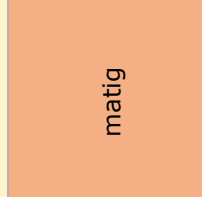 & 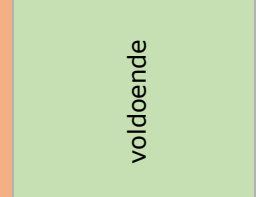 & 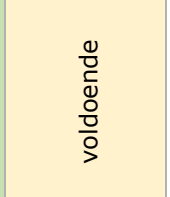 \\
\hline 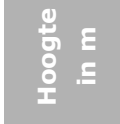 & $\stackrel{\infty}{\wedge}$ & 旁 & $\stackrel{\mathscr{N}}{\wedge}$ & $\stackrel{m}{m}$ & 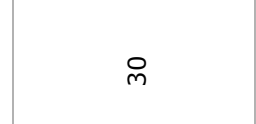 & $\stackrel{\infty}{\wedge}$ \\
\hline 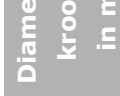 & 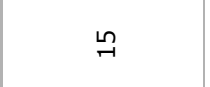 & $\infty$ & $\approx$ & $\stackrel{0}{\longrightarrow}$ & $\stackrel{\infty}{\rightarrow}$ & $\stackrel{\sim}{2}$ \\
\hline 志容 & $\infty$ & $\dot{q}$ & $\overrightarrow{0}$ & 암 & $\overrightarrow{\mathbb{N}}$ & $\stackrel{N}{\sim}$ \\
\hline & 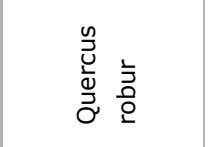 & 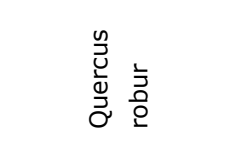 & 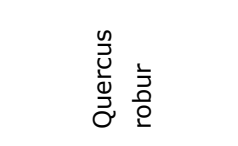 & 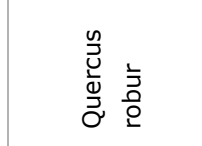 & 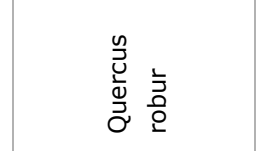 & 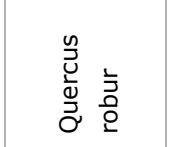 \\
\hline & $\stackrel{\varkappa}{\infty}$ & 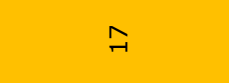 & $\stackrel{n}{q}$ & $\wedge$ & 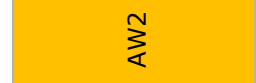 & \\
\hline
\end{tabular}




\section{Bijlage 3 Afzonderlijke jaarringcurves van alle bomen}

Beuk
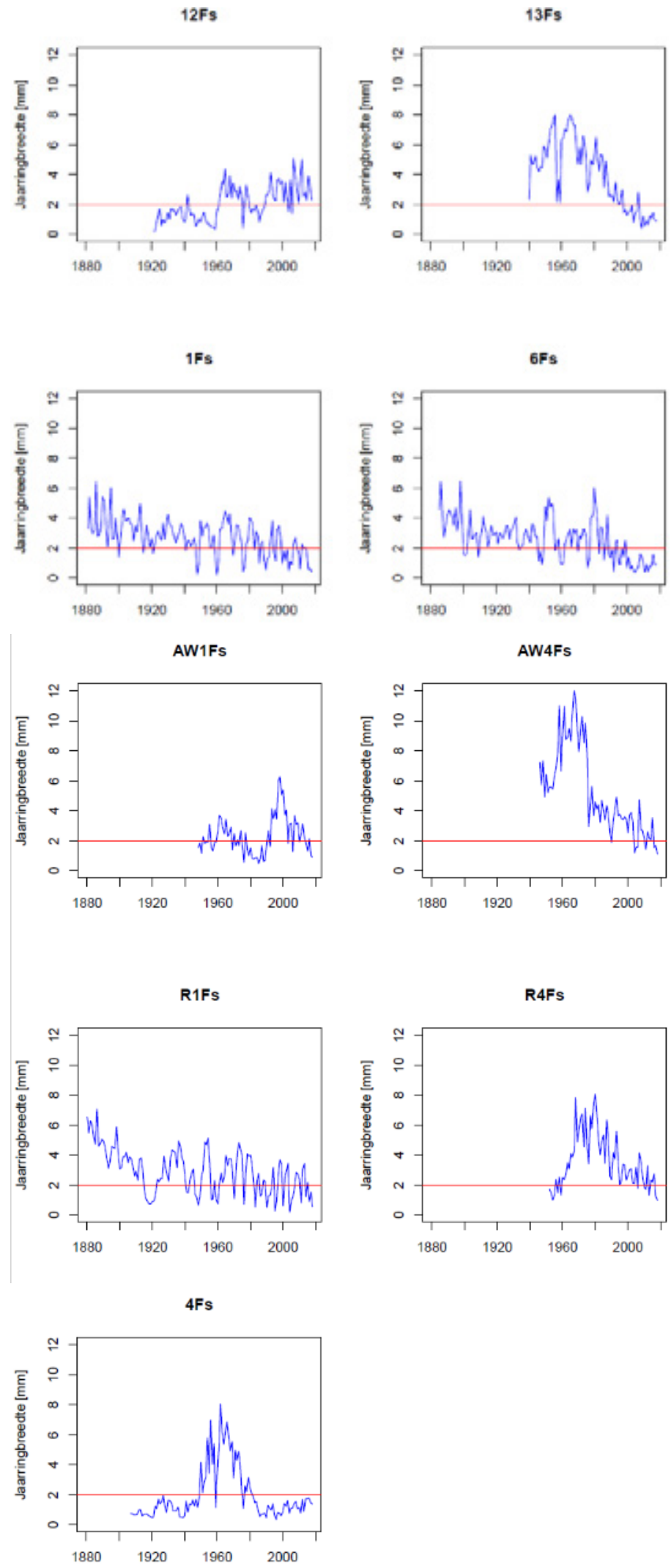
Eik

$3 Q u$

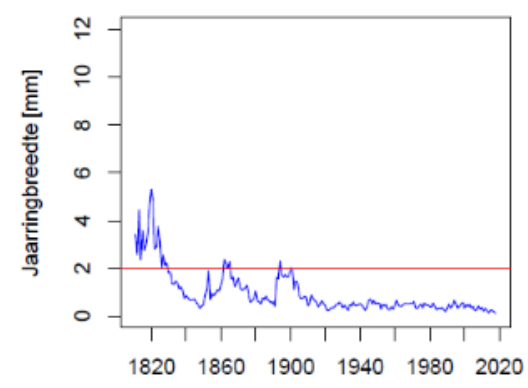

7Qu
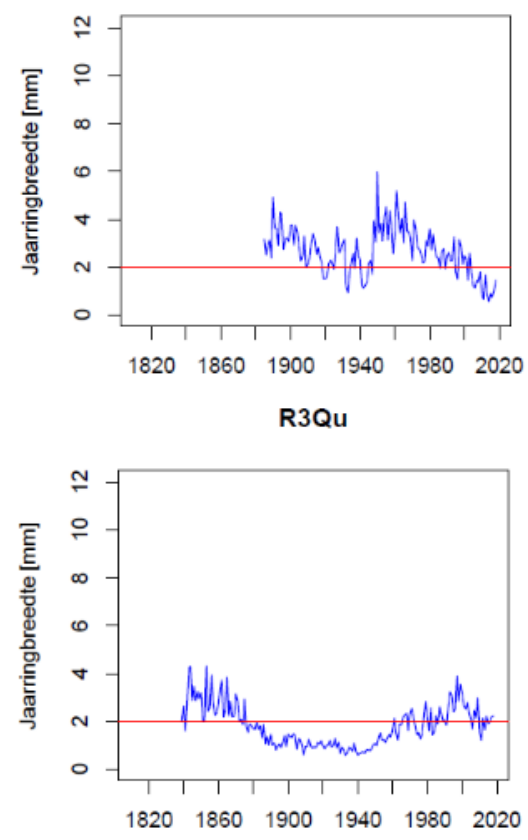

15Qu

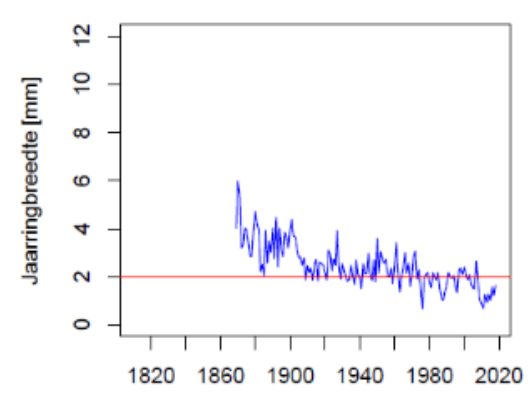

AW3Qu

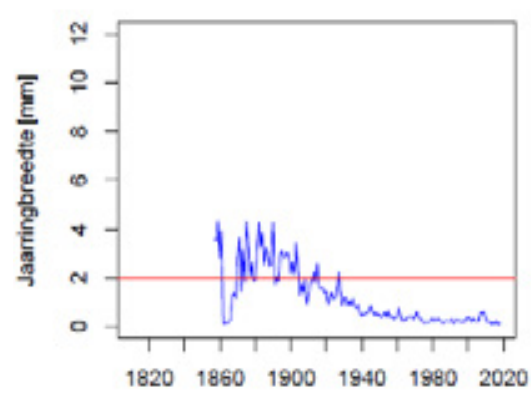

2Qu

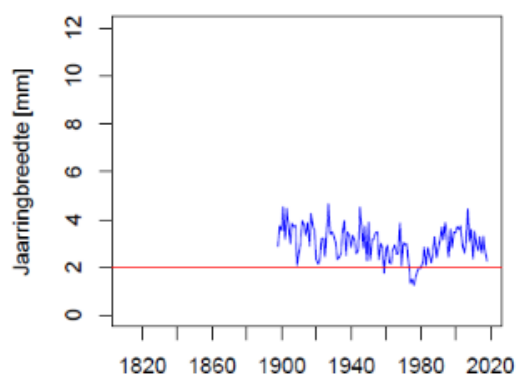

AW2Qu

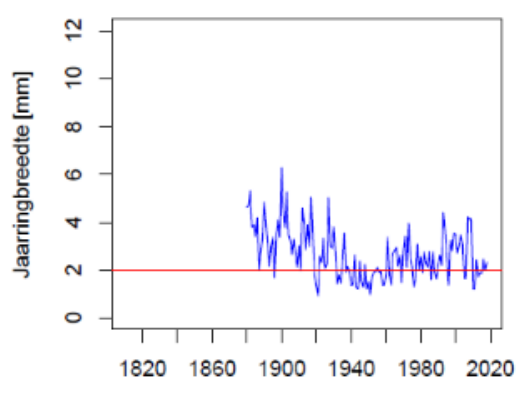

R5Qu

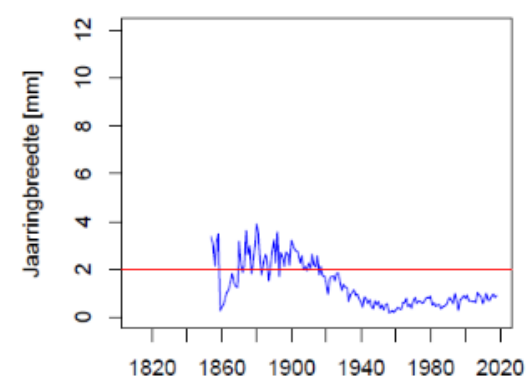

17Qu
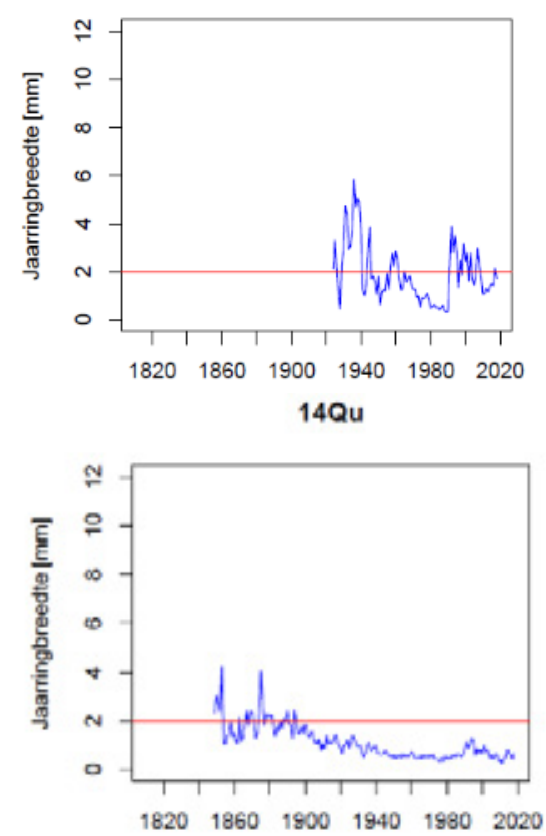
Es

10Fx

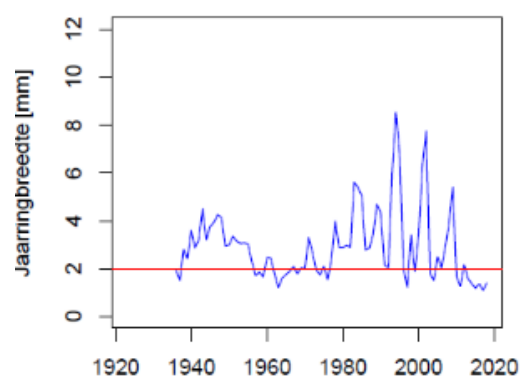

16Fx

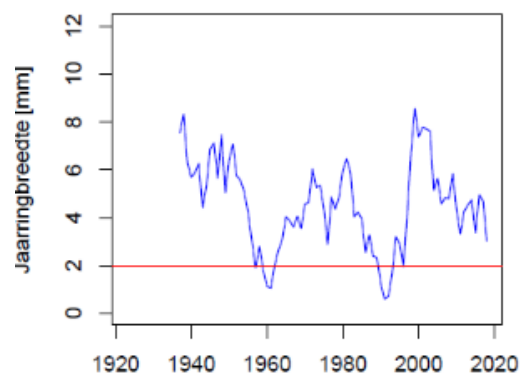

$20 \mathrm{Fx}$

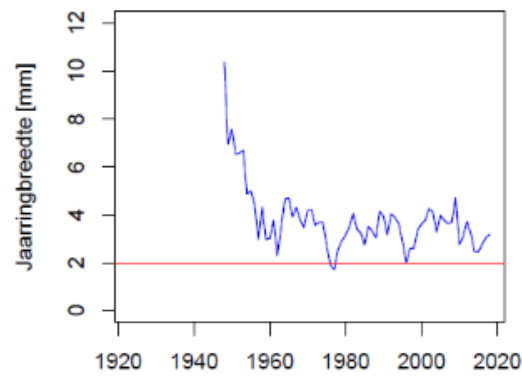

8Fx

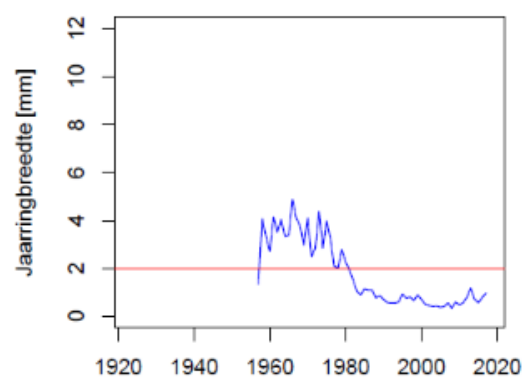

$11 \mathrm{Fx}$

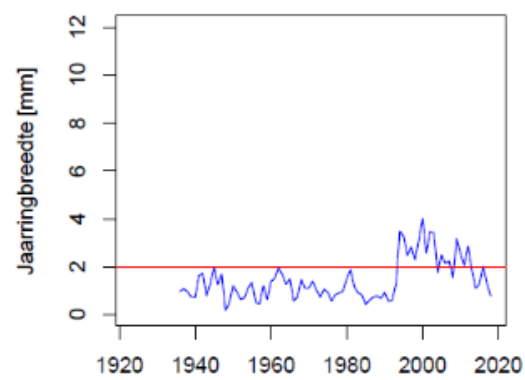

$18 F x$

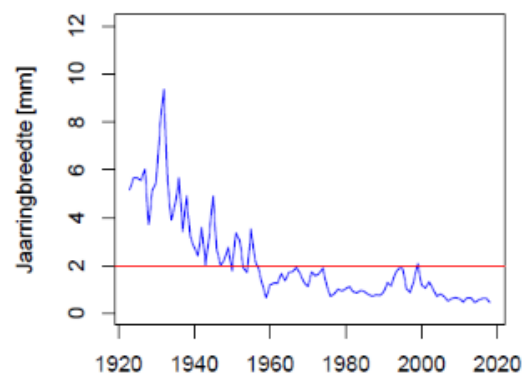

$5 F x$

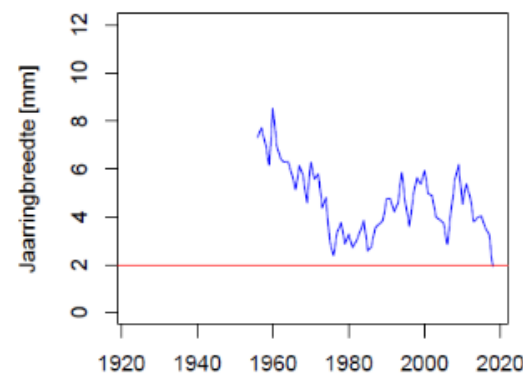

AW5Fx

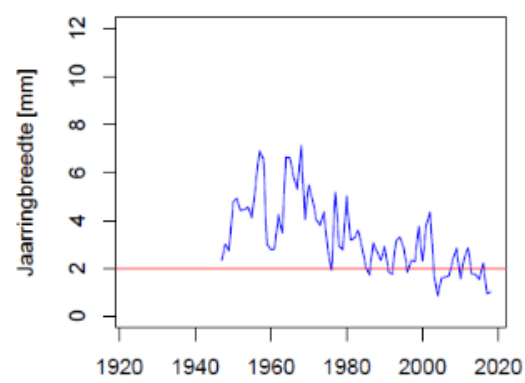


AW7Fx

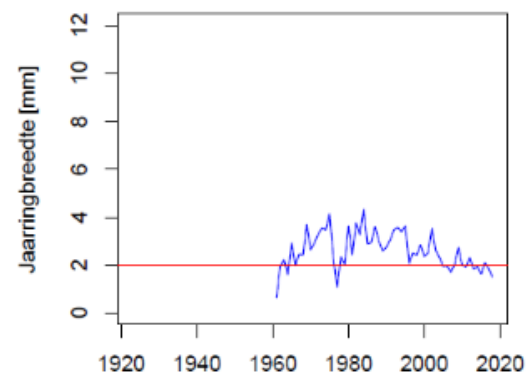

R6Fx

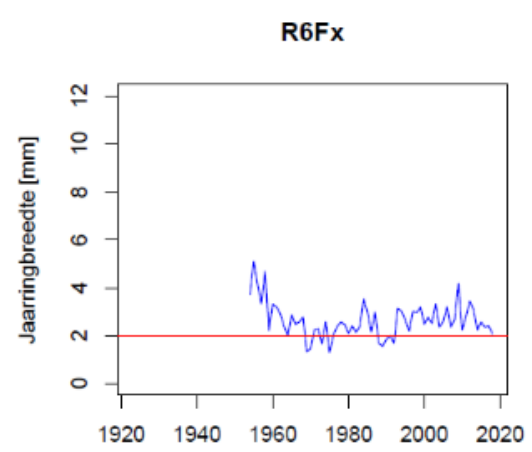

R2Fx

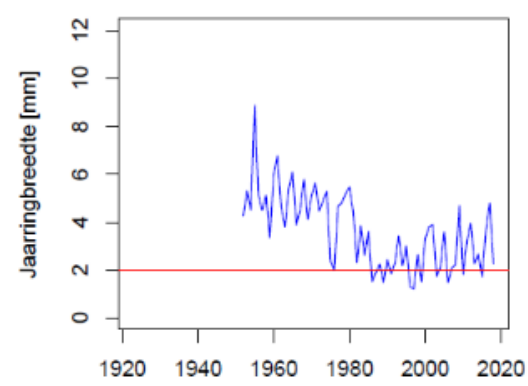


Wageningen Environmental Research Postbus 47

6700 AA Wageningen

T 0317480700

www.wur.nl/environmental-research

Wageningen Environmental Research Rapport 2926

ISSN 1566-7197
De missie van Wageningen University \& Research is 'To explore the potential of nature to improve the quality of life'. Binnen Wageningen University \& Research bundelen Wageningen University en gespecialiseerde onderzoeksinstituten van Stichting Wageningen Research hun krachten om bij te dragen aan de oplossing van belangrijke vragen in het domein van gezonde voeding en leefomgeving. Met ongeveer 30 vestigingen, 5.000 medewerkers en 10.000 studenten behoort Wageningen University \& Research wereldwijd tot de aansprekende kennisinstellingen binnen haar domein. De integrale benadering van de vraagstukken en de samenwerking tussen verschillende disciplines vormen het hart van de unieke Wageningen aanpak. 



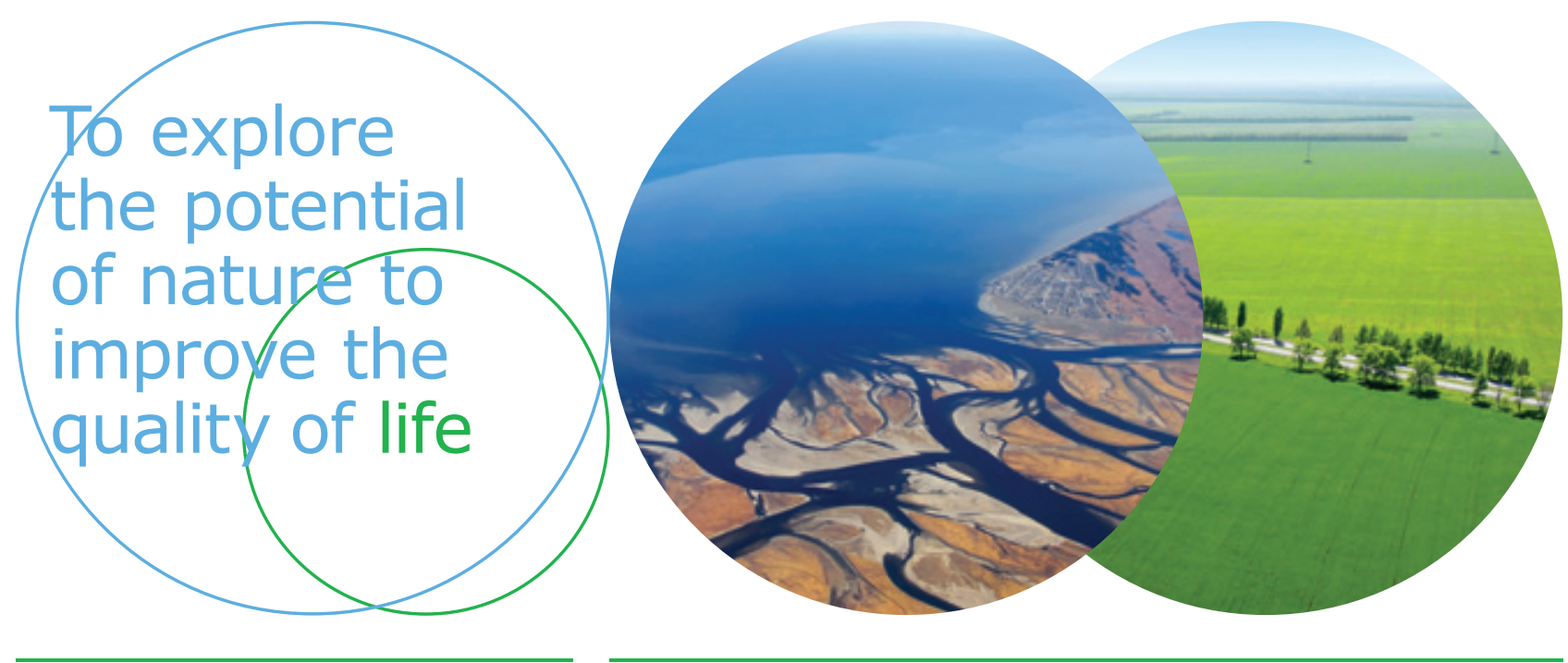

Wageningen Environmental Research Postbus 47

$6700 \mathrm{AB}$ Wageningen

T 317480700

www.wur.nl/environmental-research

Rapport 2926

ISSN 1566-7197
De missie van Wageningen University \& Research is 'To explore the potential of nature to improve the quality of life'. Binnen Wageningen University \& Research bundelen Wageningen University en gespecialiseerde onderzoeksinstituten van Stichting Wageningen Research hun krachten om bij te dragen aan de oplossing van belangrijke vragen in het domein van gezonde voeding en leefomgeving. Met ongeveer 30 vestigingen, 5.000 medewerkers en 10.000 studenten behoort Wageningen University \& Research wereldwijd tot de aansprekende kennisinstellingen binnen haar domein. De integrale benadering van de vraagstukken en de samenwerking tussen verschillende disciplines vormen het hart van de unieke Wageningen aanpak. 